

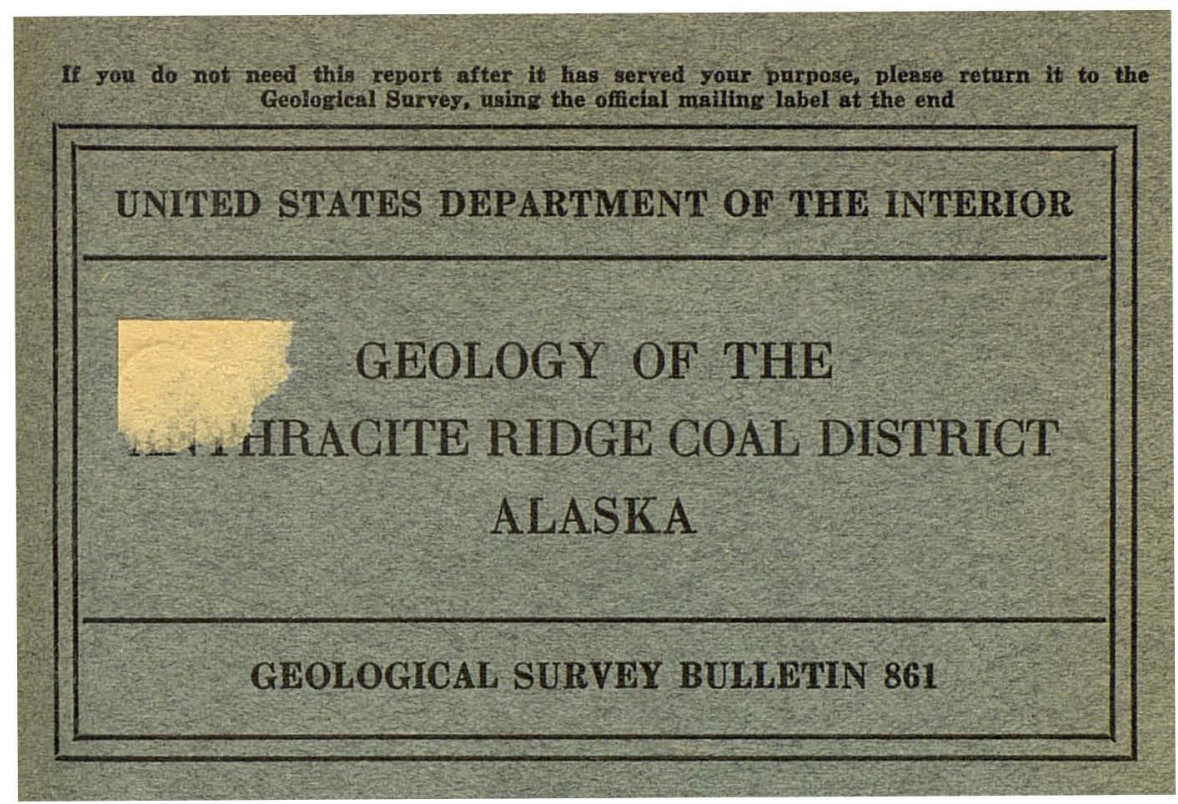


UNITED STATES DEPARTMENT OF THE INTERIOR

Harold L. Ickes, Secretary

GEOLOGICAL SURVEY

w. C. Mendenhall, Director

\section{Bulletin 861}

\section{GEOLOGY OF THE ANTHRACITE RIDGE GOAL DISTRICT ALASKA}

BY

GERALD A. WARING

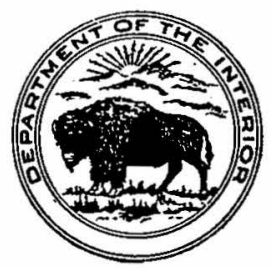

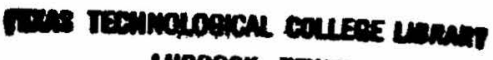

Mascex, TEres

UNITED STATES

GOVERNMENT PRINTING OFFICE

WASHINGTON : 1936

For sale by the Superintendent of Documents, Washington, D.C. - - - - Price 70 cents 


\section{CONTENTS}

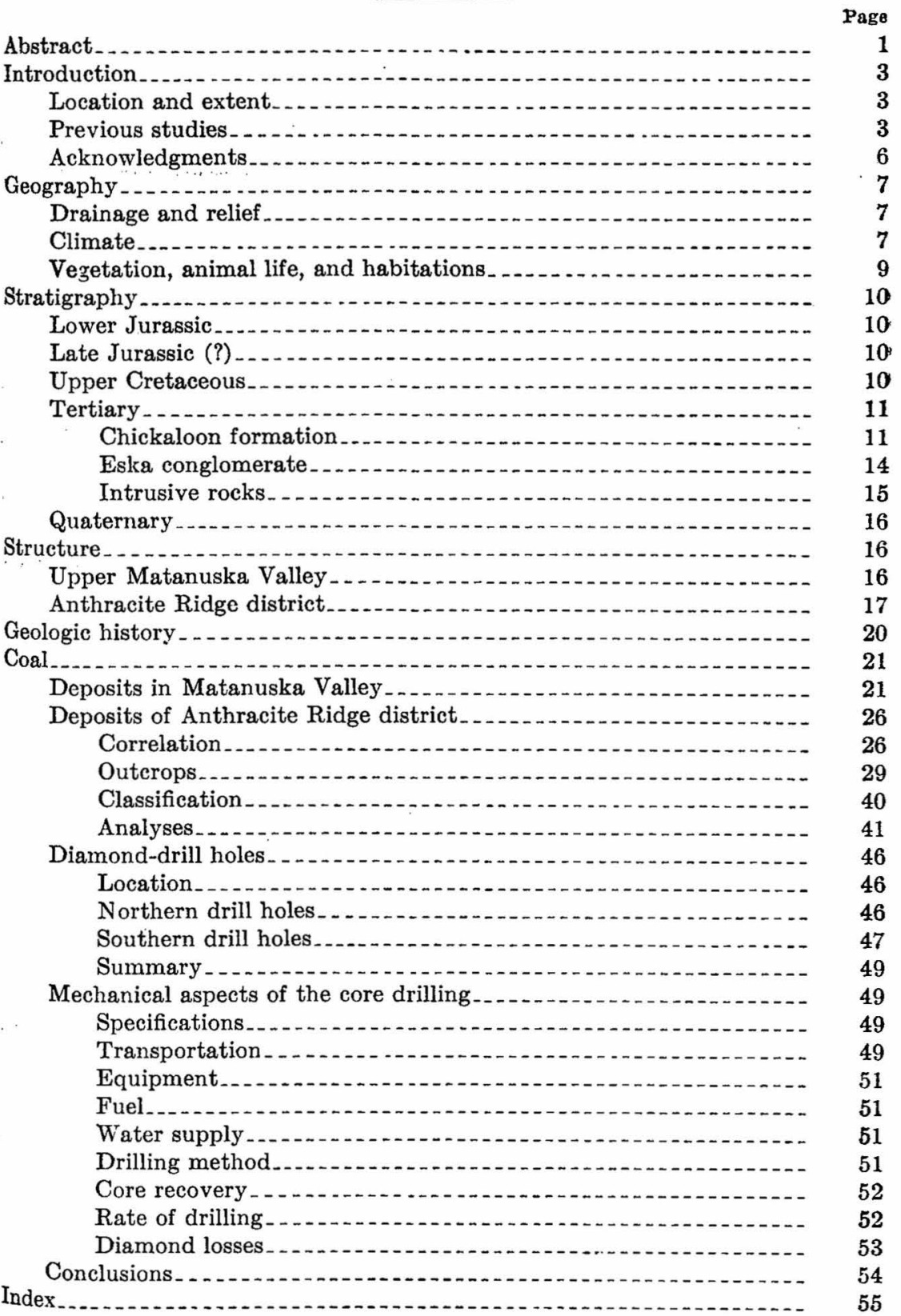




\section{ILLUSTRATIONS}

Page

Puate 1. Geologic map of the upper Matanuska Valley -.......... In pocket

2. Geologic map of the western portion of the Anthracite Ridge district........... In pocket

3. Geologic map of the eastern portion of the Anthracite Ridge district ........... In pocket

4. Geologic structure sections of the Anthracite Ridge district_. In pocket

5. A, Chugach Mountains from Anthracite Ridge; $B$, Contact of Chickaloon and Matanuska formations on upper Chikootna Creek

6. A, Structure on Anthracite Ridge east of Kutzkatna Creek; $B$, Structure on east branch of upper Cascade Creek.......

7. $A$, Western portion of Anthracite Ridge; $B$, Eastern portion

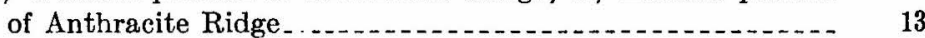

8. Structure of coal beds in sec. 12, T. 20 N., R. 7 E. ....... In pocket

9. Sections at coal outcrops in the Anthracite Ridge district.- In pocket

10. $A$, Coal beds and diabase sills on west branch of upper Purinton Creek; $B$, Folded shale and sandstone on east branch of upper

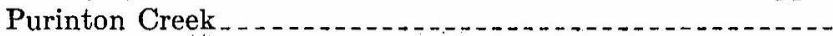

11. $A$, Thin coal beds on Muddy Creek; $B$, Coal-bearing beds on lower Purinton Creek

12. True-thickness logs of northern drill holes and corresponding section along Purinton Creek.

13. True-thickness logs of southern drill holes . . . . . . . . . In pocket

14. $A$, Diamond core drill at northwest location, Anthracite Ridge district; $B$, Diamond-drill core of sandy shale $15 / 8$ inches in diameter, $91 \frac{1}{2}$ feet long

Figure 1. Map of south-central Alaska showing location of the Anthracite Ridge coal district

2. Sections of coal-bearing beds in the Chickaloon and Coal Creek

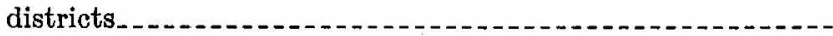

3. Percentages of materials penetrated in core drilling in the

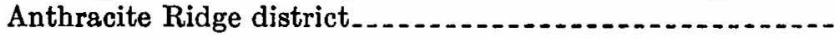




\title{
GEOLOGY OF THE ANTHRACITE RIDGE COAL DISTRICT, ALASKA
}

\author{
By GrRald A. Waring
}

\begin{abstract}
The Anthracite Ridge coal district is in south-central Alaska, about 200 miles by rail and trail from the coast at Seward. The district lies between Anthracite Ridge on the north and the Matanuska River on the south. It is about 4 miles wide and extends for 7 miles along the flank of the ridge.

The earliest geologic exploration in parts of the region was made by $\mathbf{W}$. $C$. Mendenhall, of the United States Geological Survey, in 1898. Examination and mapping was carried on at several later periods by geologists and topographers of the Survey. Early in 1931 Congress authorized the Alaska Railroad, which is Government owned and operated, to expend not more than $\$ 250,000$ for investigating the mineral resources in areas tributary to the railroad, for the purpose of stimulating their development and hence increasing the traffic and the revenues of the railroad. The technical work of carrying on these investigations was entrusted by Col. O. F. Ohlson, general manager of the railroad,
\end{abstract} to the United States Geological Survey.

One of the areas examined was the Anthracite Ridge district, where in 1931 a detailed geologic and topographic survey of the lands of chief coal interest was made by R. W. Richards and L. O. Newsome.

The older rocks of the district are overlain by the coal-bearing Chickaloon formation, consisting of fresh-water deposits of Eocene age; and these are intruded by sills and dikes of igneous rock.

Structurally, the district consists of a block formed of these sediments and intrusive rocks, faulted down between the ridge and the river and limited on the east and west by beds upturned around the ends of a general synclinal trough. Within this syncline there is minor folding and faulting. Along the middle slopes of the ridge the surficial structure is that of two minor anticlines, which are in places sharply compressed and locally faulted. This northern folded zone is cut off by a fault along the base of the ridge, marked by cliffs and waterfalls. The zone thence southward toward the river is in the main a broad syncline, but it contains a few minor anticlinal folds and slice faults.

Coal beds are exposed in three main areas within the district-at the north, on the central part of the ridge; at the east, in the basin of Muddy Creek; and at the southwest, along lower Purinton Creek.

About 90 coal outcrops in the district were examined, and numerous geologic sections were measured and compared. All the coal beds are of moderate extent. Some pinch out, and others grade within short distances into shales. The observations on the structure of the rocks indicate that there are three coal-bearing zones, all low in the Chickaloon formation. 
The thickest beds of coal, which are also those of highest rank, are in the northem area. The principal beds there are in the highest zone and in two exposures show 34 and 24 feet of clean coal, but this is considerably shattered. To the east and west this coal zone thins rapidly. The middle zone lies about 120 feet deeper and locally shows coal and bone as much as 10 feet in thickness. Westward this zone thins rapidly, but eastward it thickens and contains several beds of coal. This zone seems to be 600 or 700 feet above the base of the Chickaloon formation, which overlies marine deposits of Upper Cretaceous age. The lowest coal zone is not present in this area.

These coals are semianthracite to anthracite, having been altered from coals of lower rank. Probably this change was produced chiefly by heat from the intruding masses of igneous rock, which drove off some of the volatile matter from the coal. The heat resulting from the later compression and folding of the beds may also in some places have been an agent in their alteration.

The coal beds of the eastern area belong mainly to the middle zone and consist of four or five beds with a total of about 10 feet of coal in a zone 50 feet thick. Although these coals have been in places closely folded, they have not been appreciably altered and are of bituminous rank. On middle Muddy Creek the lowest coal zone is exposed and consists of a 6 -foot bed of bituminous coal 140 feet below the middle zone.

In the southwest area there are about six coal beds, distributed through a thickness of nearly 400 feet of sediments. The uppermost bed seems to be about equivalent to the upper coals of the northern area, and the others accord approximately with the middle and lower coal zones. These southwestern coals are bituminous to semibituminous in rank.

Although the studies indicated that the outcropping beds of coal are not of great economic importance at present because of their irregular character and broken condition, evidence was obtained which indicated that the highrank coals might be present, less broken and of great potential value, beneath the synclinal area south of the principal outcrops. This area was tested in 1932 by eight diamond-drill holes, a total of 8,000 feet being core drilled.

Observations on the dip of the strata indicated that the horizon of the anthracite would be found at a depth of 1,500 or 1,600 feet. The deepest hole renched 1,820 feet. It penetrated numerous beds of black shale containing plant remains, and between the depths of 1,300 and 1,550 feet there were several layer's of carbonaceous shale and small amounts of coal gas, but no coal other than veinlets $1 / 32$ to $1 / 8$ inch in thickness was found. None of the other drill holes encountered coal beds, though cohl veinlets in the shale, and fragments of coal in the sandstone and conglomerate were found at many horizons. During the period or periods of coal deposition the present synclinal area apparently was not an area in which coal was formed.

Except for a few locally altered lenses, all the known coal of anthracite rank in the district is confined to an area half a mile long and a quarter of a mile wide, on the south flank of the ridge. This area is folded and faulted, and the coal becls are much shattered, with inclusions of bone and shale and intrusions of igneous rock. The amount of coal in the most promising 20 acres of this area has been estimated at 750,000 tons. The tract lies high on the side of the ridge, 2,500 to 3,000 feet above the river and nearly 20 miles from the former railroad terminus at Chickaloon.

All the other beds of workable thickness in the district are of semibituminous and bituminous coals. Their outcrops are of small extent, and the beds are so irregular in thickness that estimates of available tonnage cannot be made on the basis of present information. Much detailed prospecting supplemented by trenching and core drilling would be necessary for this purpose. 
Chemical analyses show that none of these coals have appreciable fuel adrantage over the more accessible deposits being mined in the western part of the Matanuska Valley.

Although the district probably contains several million tons of bituminous Coal, in addition to the 750,000 tons of anthracite and semianthracite, the beds are broken and irregular in thickness, and much dead work would be involved in mining. Local demand is so small and other markets are so remote that attempts to produce coal from the district in competition with more accessible areas is not warranted at the present time.

\section{INTRODUCTION}

\section{LOCATION AND EXTENT}

The Anthracite Ridge coal district is in south-central Alaska; on the north side of the valley of the Matanuska River, which empties into the northeast arm of Cook Inlet. (See fig. 1.) The district is most easily reached by the Alaska Railroad, which has a branch line from Matanuska station, near the mouth of the river, 150.7 miles by rail from the seaport at Seward. The branch line extends eastward along the north bank of the Matanuska River 19 miles to Sutton, and thence it is nearly 19 miles farther along the abandoned railroad bed to the former rail terminus at Chickaloon. From Chickaloon it is about 18 miles by trail eastward to the center of the Anthracite Ridge district.

The district considered in the present report is limited by Anthracite Ridge on the north, the Matanuska River on the south, Packsaddle Gulch on the east, and Sawmill Creek on the west. This area is about 4 miles wide and extends for 7 miles along the front of the ridge. Its position with respect to the former rail terminus at Chickaloon and the coal deposits there is shown on plate 1, and the geology of the district js shown in more detail in plates 2,3 , and 4 .

\section{PREVIOUS STUdIES}

The first geologic exploration of the Matanuska Valley was made in 1898 , when it was traversed by W. C. Mendenhall, of the United States Geological Survey, attached as geologist to a military expedition in charge of Capt. Edwin F. Glenn, Twenty-fifth Infantry, United States Army. Mendenhall's report ${ }^{1}$ includes a topographic map of the region and descriptions of the geographic and geologic features.

The coal deposits of the Matanuska Valley, including those of the Anthracite Ridge district, were hastily examined by G. C. Martin in 1905 , and his report ${ }^{2}$ contains measurements of the coal beds and analyses of representative samples.

\footnotetext{
${ }^{1}$ Mendenhall. W. C., A reconnaissance from Resurrection Bay to the Tanana River, Alaska, in 1898 : U. S. Geol. Survey 20th Ann. Rept., pt. 7, pp. 265-340, 1900.

'Martin, G. C., A reconnaissnnce of the Matanuska coal fleld, Alaska, in 1905: U. S. Geol. Survey Eull. 289, 1906.
} 


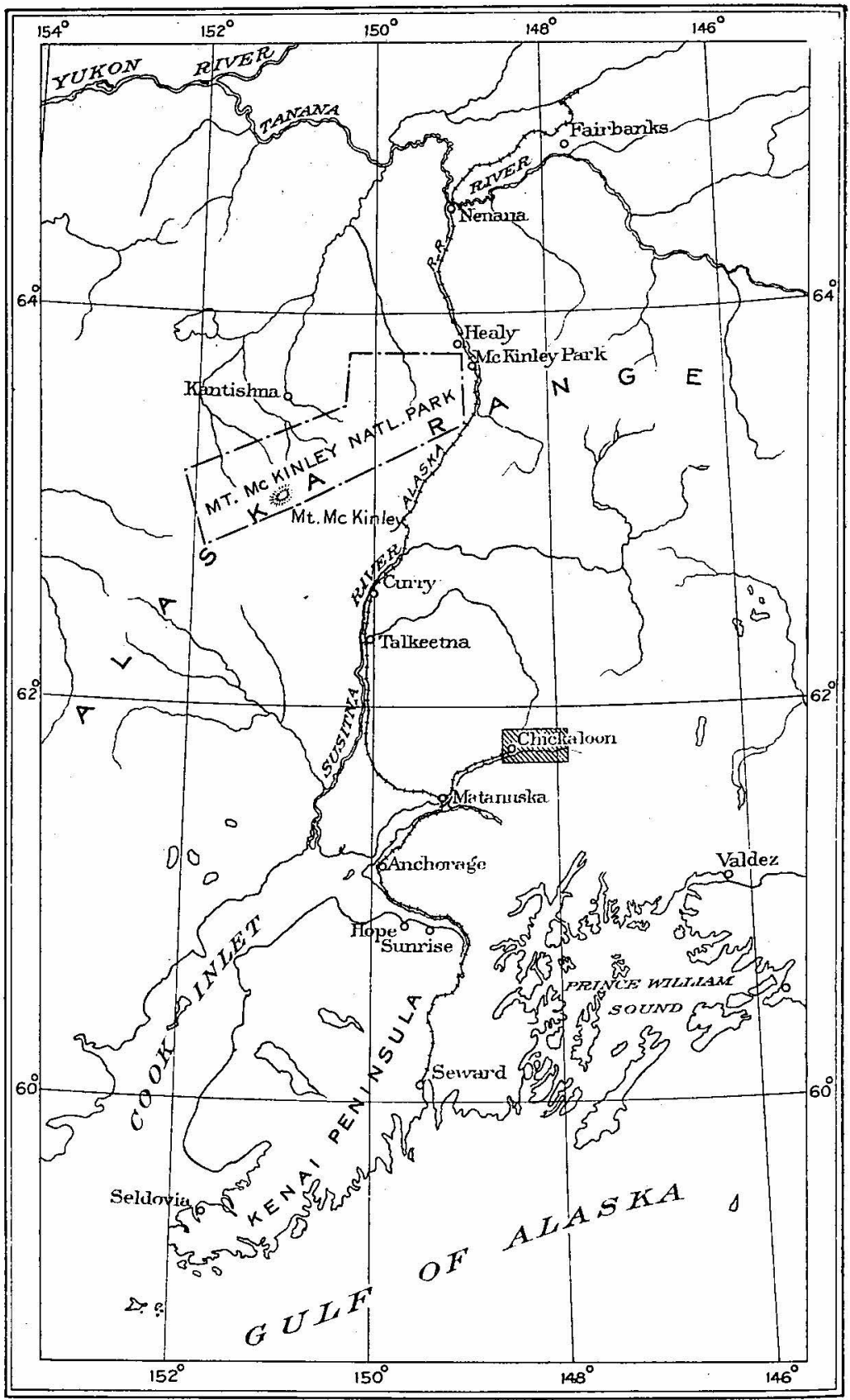

50 50 100 MILES

Figuas 1.-Map of south-central Alaska showing location of the Anthracite Ridge coal district. 


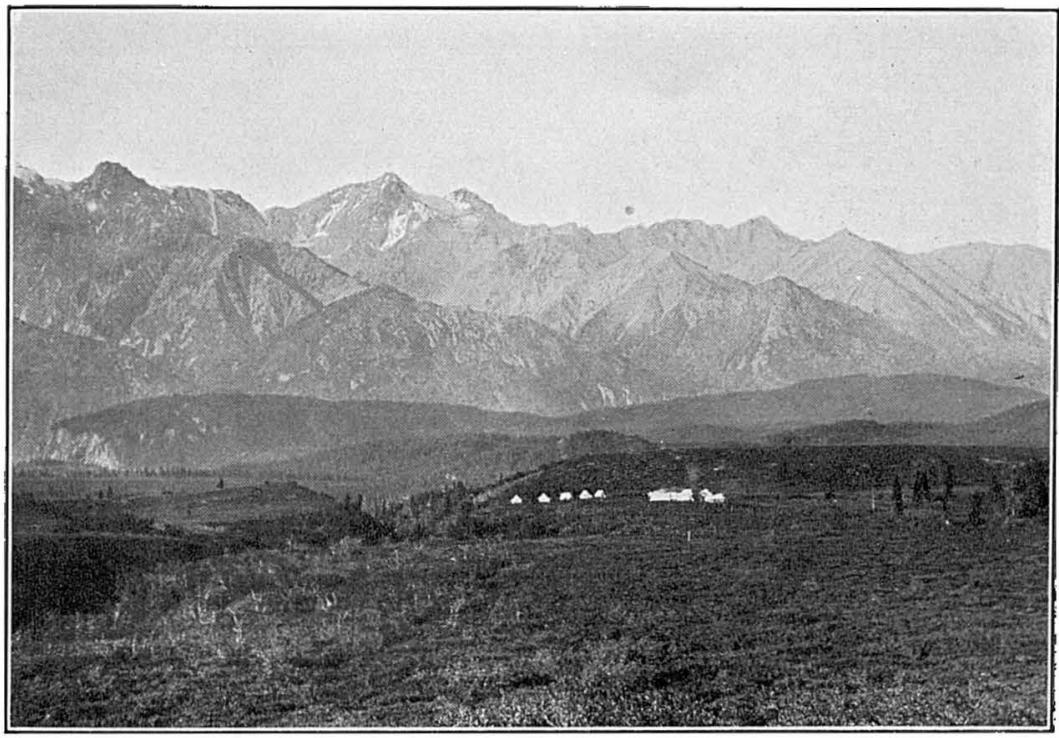

A. CHUGaCH MOUNTAINS FROM ANTHRACITE RIDGE.

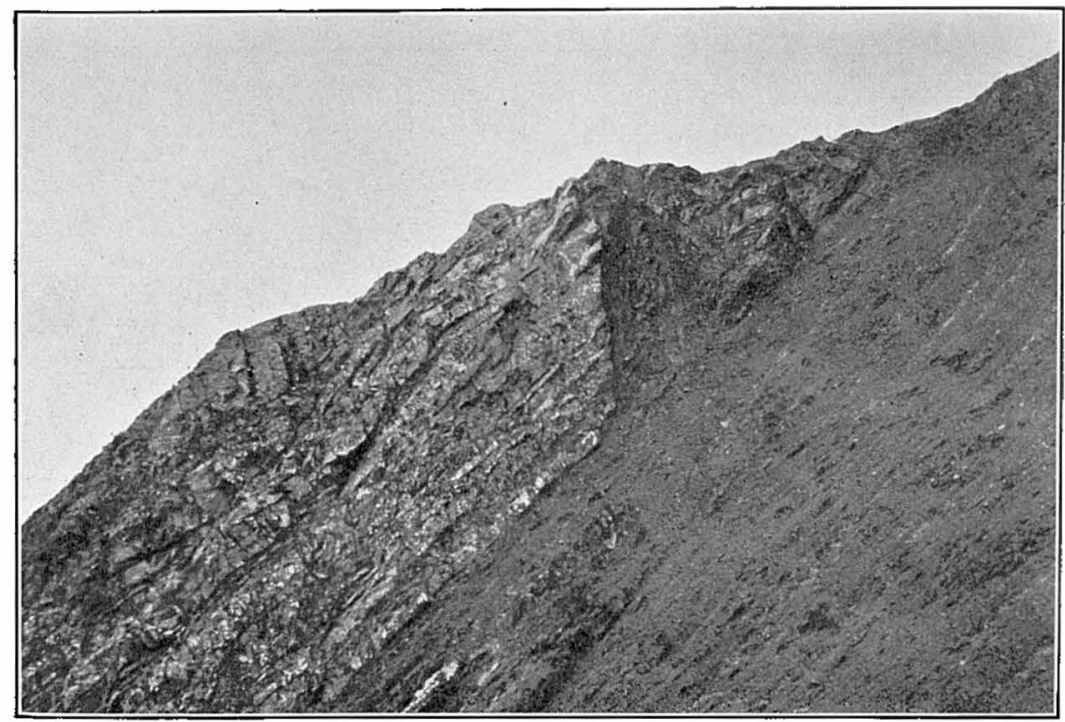

B. CONTACT OF CHICKALOON AND MATANUSKA FORMATIONS ON UPPER CHIKOOTNA CREEK.

Chickiloon at left; Matanuska at right. 


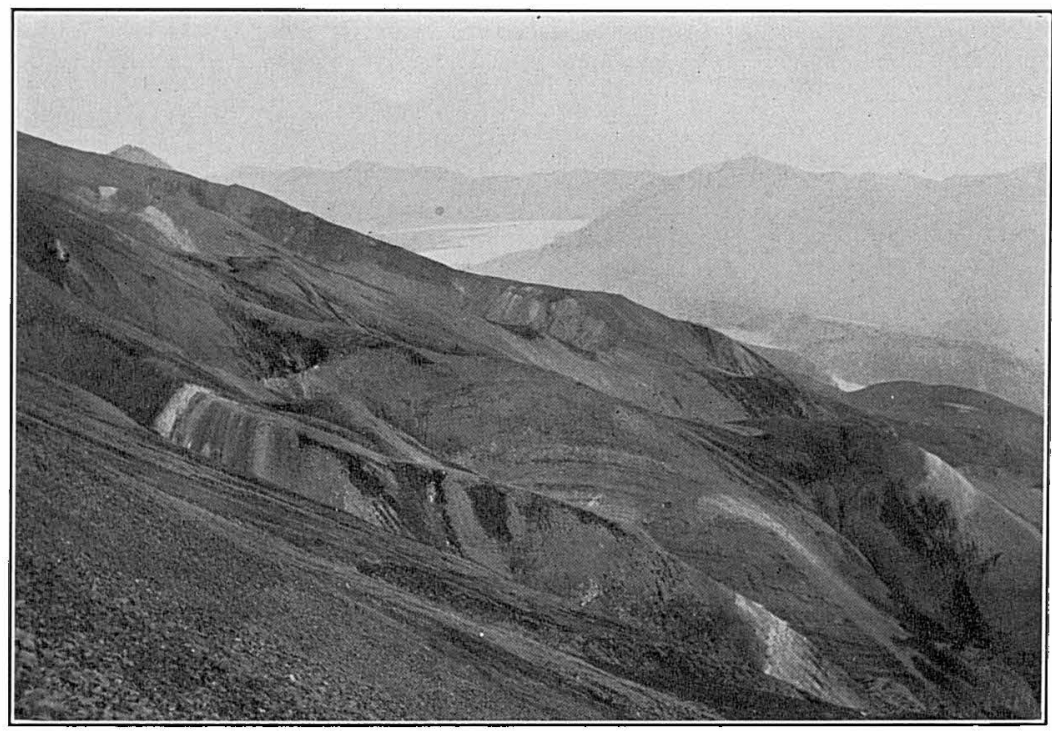

A. STRUCTURE ON ANTHRACITE RIDGE EAST OF KUTZKATNA CREEK.

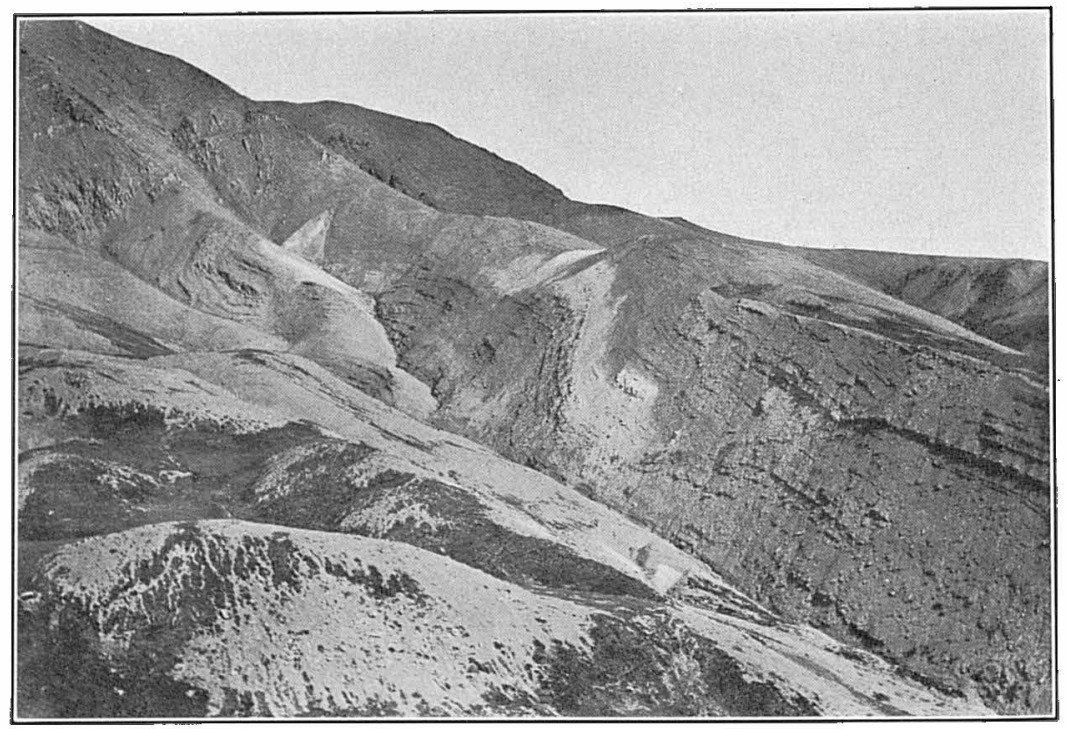

B. STRUCTURE ON EAST BRANCH OF UPPER CASCADE CREEK. 


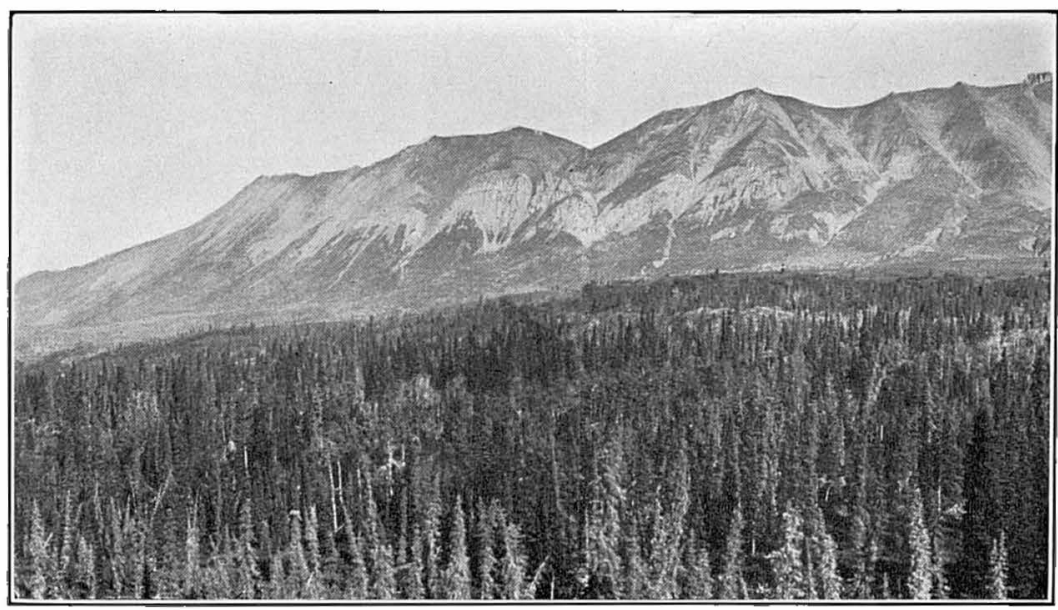

A. WESTERN PORTION OF ANTHRACITE RIDGE.

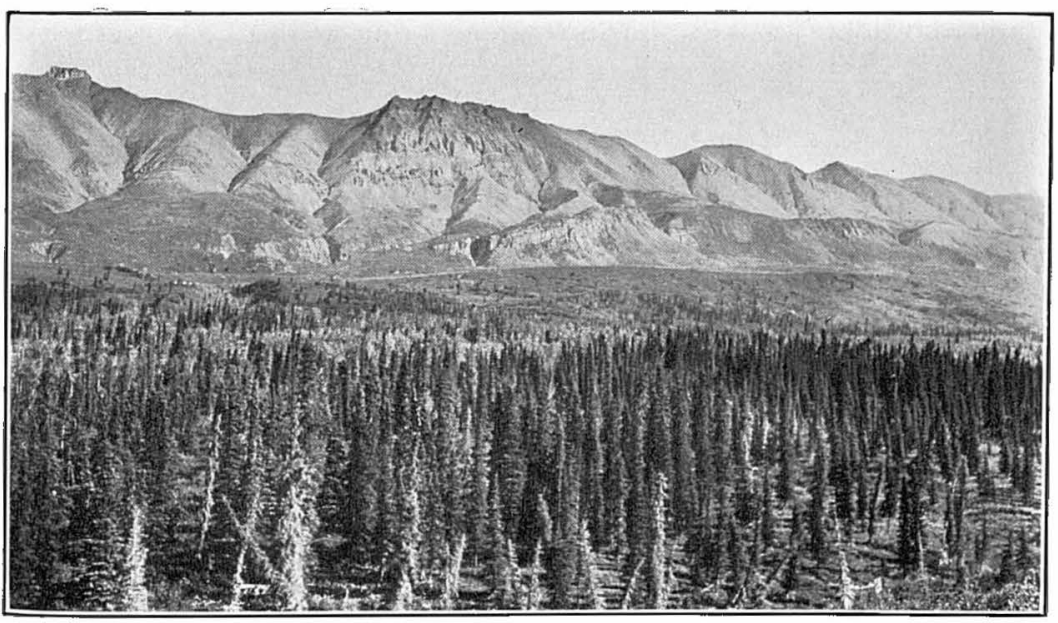

B. EASTERN PORTION OF ANTHRACITE RIDGE. 
The region was visited in 1906 by a party of the Geological Survey in charge of T. G. Gerdine, topographer, with R. H. Sargent, topographer, and Sidney Paige and Adolph Knopf, geologists. The geologists' report ${ }^{3}$ described in some detail the Mesozoic and Tertiary rocks and was accompanied by a map showing their areal distribution.

In 1909 a topographic survey in charge of R. H. Sargent was carried out in the lower Matanuska Valley, and in 1910 a detailed geologic survey of that area was made by G. C. Martin and F. J. Katz, assisted by Theodore Chapin. The report on this work ${ }^{4}$ was published in 1912.

A detailed topographic map of part of the Matanuska Valley lying east of the area previously mapped was made by R. H. Sargent in 1913, and geologic studies were made in the same year by G. C. Martin and J. B. Mertie, Jr., assisted by R. M. Overbeck, special attention being paid to the coal deposits. A preliminary report on this work ${ }^{5}$ was published in 1914, and work was begun on a more detailed report but was delayed by conditions due to the World War. Meanwhile the railroad had been extended to Chickaloon in October 1917, and coal mines, primarily for the railroad needs, had been developed in the lower part of the valley. In 1917 Martin revisited the area, and the results of his observations ${ }^{6}$ were published two years later. In 1918-19 Theodore Chapin made studies of the structure of the coal beds, and his work was published in two reports. ${ }^{7}$

From July 1, 1920, to April 30, 1922, the Navy Alaskan Coal Commission did exploratory work on the coal beds at Chickaloon, and the final report on this work, ${ }^{8}$ by Capt. W. P. T. Hill, includes studies and recommendations by himself and his assistants, T. E. Savage and W. T. Foran, concerning the coal deposits in the Anthracite Ridge district.

In 1924 S. R. Capps, assisted by K. K. Landes, spent several weeks in the region, studying especially the geology of the Anthracite Ridge district and of the Chugach Mountains along the south side of the Matanuska River. The report covering this work ${ }^{9}$ includes

\footnotetext{
${ }^{3}$ Paige, Sidney, and Knopf, Adolph, Geologic reconnaissance in the Matanuska and Talkeetna Basins, Alaska: U. S. Geol. Survey Bull. 327, 1907.

* Martin, G. C., and Katz, F. J., Geology and coal fields of the lower Matanuska Valley, Alaska : U. S. Geol. Survey Bull. 500, 1912.

${ }^{5}$ Martin, G. C., and Mertie, J. B., Jr., Mineral rescurces of the upper Matanuska and Nelchina Valleys; ర. S. Geol. Surrey Bull. 592, pp. 273-299, 1914.

${ }^{6}$ Martin, G. C., Geologic problems at the Matanuska coal mines: U. S. Geol. Survey Bull. 692, pp. 269-282, 1919.

${ }^{7}$ Chapin, Theodore, Mining developments in the Matanuska coal field: U. S. Geol. Survey Bull. 712, pp. 131-167, 1920; Bull. 714, pp. 197-199, 1921.

${ }^{8}$ Hill, W. P. T., Final report of the Navy Alaskan Coal Commission to the Secretary of the Navy, 1922 (manuscript).

${ }^{\circ}$ Capps, S. R., Geology of the upper Matanuska Valley, Alaska, with a section on the igneous rocks, by J. B. Mertie, Jr.: U. S. Geol. Survey Bull. 791, 1927.
} 
also much previously unpublished information obtained by Martin and Mertie in 1913 and by Chapin in 1918-19.

In 1930 a special committee of the United States Senate, composed of Senators Howell, Kendrick, and Thomas, visited Alaska in order to study the problem of increasing the revenues of the railroad, which is owned and operated by the Government. Through their recommendations Congress authorized the railroad to expend a sum not to exceed $\$ 250,000$ for investigating the mineral resources in areas tributary to the railroad, for the purpose of stimulating their development and hence increasing the freight and passenger traffic. The technical work of carrying on these investigations was entrusted by Col. O. F. Ohlson, general manager of the railroad, to the United States Geological Survey.

As one part of these examinations a detailed study of the coal deposits of the Anthracite Ridge district was made in 1931, with R. W. Richards as geologist and L. O. Newsome as topographer. During the second half of the season G. A. Waring assisted in the geologic work. The preliminary results of these studies have been published. ${ }^{10}$ Although they indicated that the outcropping coal beds are not of great economic importance at present, because of their irregular character and broken condition and the low rank of most of the coals, evidence was obtained which indicated that high-rank coals, less broken and of greater potential value, might be found underlying an area to the south of the principal outcrops. It was accordingly decided to test this area by core drilling. This work was carried out during June to December 1932, and the results are contained in the present report, which also includes detailed geologic studies of the preceding season and the detailed topographic map by Newsome. The earlier reports on the region have been freely drawn upon for information on the general geology.

\section{ACKNOWLEDGMENTS}

During the season of $1932 \mathrm{Mr}$. T. N. Scott ably assisted the writer as recorder for the core drilling and as field assistant in geologic work. Mr. P. H. Hart acted as cook, and for part of the season Mr. L. A. Oules was packer, this work later being done by Messrs. B. B. Ueeck and Lee Harrison. Mr. and Mrs. R. S. Heckey, at Chickaloon, were of great assistance in many ways to both the geologic and the core-drilling parties.

The core drilling was done under contract by Lynch Brothers, of Seattle, Wash., and owing to the untiring energy of their drill foreman, Mr. John Flink, the work was satisfactorily completed in spite of various difficulties.

\footnotetext{
${ }^{10}$ Richards, R. W., and Waring, G. A., Progress of surveys in the Anthracte Ridge dis trict, Alaska : U. S. Geol. Survey Bull. 849-A, 1933.
} 
Samples of coal from the district were analyzed by Mr. Maurice L. Sharp; chemist of the United States Bureau of Mines, stationed at Anchorage.

To Mr. J. J. Corey; mining engineer of the Geological Survey, and to Col. O. F. Ohlson, general manager of the Alaska Railroad, and meinbers of his staff, thanks are due for much assistance in transportation and obtaining supplies.

\section{GEOGRAPHY}

\section{DRAINAGE AND RELIEF}

All of the district drains southward to the Matanuska River, the principal streams being Purinton, Cascade, Winding, and Muddy Creeks. Packsaddle Gulch on the east and the headwaters of Sawmill Creek on the west, may be taken as the limits of the district with respect to coal deposits. All these streams and their larger tributaries carry water during the open season and also probably flow throughout the winter in their lower courses, under the protecting cover of ice and snow.

The Matanuska River flows in a flat-bottomed valley half a mile to 1 mile in width, in branching channels separated by gravel bars. During most of the summer its main channels are too deep to be forded safely, but a short distance above the mouth of Muddy Creek the river is usually fordable by horses. From about December 15 to March 15 the channels are frozen over and the river valley is used as a route for horses and $\operatorname{dog}$ teams to take supplies into mining districts farther east. The river valley in the southwest corner of the district is about 1,100 feet above sea level. It is bordered on the north by bluffs that rise 200 to 500 feet above the river. Thence the slope is moderate up to the base of Anthracite Ridge, at an elevation of 2,800 to 3,000 feet. The slopes rise steeply from the base to the crest of the ridge, at 4,100 to 6,350 feet.

\section{CLIMATE}

The upper Matanuska Valley is far enough inland from Cook Inlet to have a climate more like that of the interior than of the seacoast. The summers are mild, with maximum temperatures of about $75^{\circ}$, but winter temperatures of $20^{\circ}$ to $30^{\circ}$ below zero are not uncommon. During the summer the wind blows prevailingly from the west up the valley, but in the fall it changes to a downstream wind, which renders travel along the river at times severely uncomfortable.

The record of monthly precipitation and highest and lowest temperatures kept at Chickaloon during the 5 year's 1928-32, and similar 
data recorded at the drilling camp during the season of 1932 are given in the following tables. Although the two stations differ by 1,500 feet in elevation, their temperatures differed little during the summer. In December the minimum temperatures probably were lower at Chickaloon than on the upland. The summer rainfall was considerably heavier on the upland. In the early spring there was 4 to 6 feet of snow on the slopes of the ridge, as compared with about $21 / 2$ feet at Chickaloon.

Weather record at Chickaloon, Alaska, 1928-32

[From U. s. Weather Buresu. Elevation 930 feet]

Temperature $\left({ }^{\circ}\right.$ F.)

\begin{tabular}{|c|c|c|c|c|c|c|c|c|c|c|c|c|c|}
\hline & Jan. & Feb. & Mar. & Apr. & May & June & July & Ang. & Sept. & Oct. & Nov. & Dec. & $\begin{array}{l}\text { An- } \\
\text { nual }\end{array}$ \\
\hline \multicolumn{14}{|l|}{ Highest: } \\
\hline 1928 & 30 & 42 & 42 & 52 & 73 & 80 & 79 & 77 & 67 & 52 & 50 & 35 & \\
\hline $\begin{array}{l}1929 \\
1930\end{array}$ & $\begin{array}{l}36 \\
33\end{array}$ & $\begin{array}{l}39 \\
35\end{array}$ & $\begin{array}{l}49 \\
50\end{array}$ & $\begin{array}{l}57 \\
55\end{array}$ & $\begin{array}{l}63 \\
67\end{array}$ & $\begin{array}{l}76 \\
80\end{array}$ & $\begin{array}{l}76 \\
79\end{array}$ & $\begin{array}{l}79 \\
80\end{array}$ & $\begin{array}{l}72 \\
70\end{array}$ & $\begin{array}{l}53 \\
49\end{array}$ & 38 & 34 & $\ldots$ \\
\hline 1931 . & & & & & & 82 & 75 & 74 & 66 & 56 & 42 & 30 & \\
\hline 1932 & 31 & 34 & 49 & 55 & 68 & 77 & 78 & 68 & 64 & 62 & 30 & 31 & \\
\hline \multicolumn{14}{|l|}{ Lowest: } \\
\hline $1928 \ldots$ & $\begin{array}{l}-12 \\
-17\end{array}$ & $\begin{array}{r}-6 \\
-14\end{array}$ & -12 & $-20^{2}$ & 22 & 32 & 29 & 30 & 17 & 8 & -17 & -12 & \\
\hline $1930 \ldots$ & -24 & -27 & -30 & -9 & 24 & 26 & 38 & $\begin{array}{l}00 \\
36\end{array}$ & 13 & 3 & & & \\
\hline $1931 \ldots$ & & & & & & 28 & 35 & 31 & 20 & 6 & -30 & -26 & \\
\hline \multirow{2}{*}{\multicolumn{14}{|c|}{ Mean: }} \\
\hline & & & & & & & & & & & & & \\
\hline $\begin{array}{l}1928 . \\
1929 .\end{array}$ & $\begin{array}{l}13.0 \\
15.1\end{array}$ & $\begin{array}{l}19.6 \\
19.4\end{array}$ & $\begin{array}{l}20.0 \\
18.0\end{array}$ & $\begin{array}{l}32.5 \\
27.4\end{array}$ & $\begin{array}{l}43.4 \\
43.4\end{array}$ & $\begin{array}{l}53.3 \\
54.6\end{array}$ & $\begin{array}{l}54.8 \\
55.2\end{array}$ & $\begin{array}{l}53.4 \\
53.0\end{array}$ & $\begin{array}{l}43.6 \\
50.8\end{array}$ & $\begin{array}{l}32.8 \\
35.8\end{array}$ & $\begin{array}{l}20.8 \\
22.1\end{array}$ & $\begin{array}{r}15.6 \\
8.6\end{array}$ & $\begin{array}{l}33.6 \\
33.6\end{array}$ \\
\hline $1930 \ldots$ & 8.5 & 3.6 & 17.0 & 28.5 & 41.8 & 53.2 & 57.5 & 56.4 & 44.6 & 29.2 & & & \\
\hline 1931 & & & & & & & 54.8 & 54.7 & 45.2 & 31.6 & 19.8 & 9.9 & \\
\hline & -1.6 & 4.4 & 24.9 & 33.7 & 43.4 & 49.8 & 54.6 & 50.6 & 42.3 & 35.0 & 13.2 & 8.6 & 29.9 \\
\hline Normal. & 8.3 & 13.9 & 19.5 & 30.7 & 44.5 & 53.2 & 56.3 & 54.1 & 45.6 & 32.9 & 18.8 & 10.2 & 32.3 \\
\hline $\begin{array}{l}\text { Length of record } \\
\text { (years) }\end{array}$ & 14 & 15 & 15 & 15 & 16 & 17 & 17 & 16 & 14 & 15 & 14 & 14 & \\
\hline
\end{tabular}

Preciptation (inches)

\begin{tabular}{|c|c|c|c|c|c|c|c|c|c|c|c|c|c|}
\hline $\begin{array}{l}1928 \\
1929 \\
1930 \\
1931 \\
1932\end{array}$ & $\begin{array}{l}0.98 \\
1.90 \\
1.15\end{array}$ & $\begin{array}{r}2.25 \\
2.19 \\
.14\end{array}$ & $\begin{array}{l}0.85 \\
2.55 \\
4.20\end{array}$ & $\begin{array}{r}0.60 \\
.45 \\
.47\end{array}$ & $\begin{array}{r}0.78 \\
.23 \\
.22\end{array}$ & $\begin{array}{l}0.69 \\
1.33 \\
.59 \\
1.04 \\
1.73\end{array}$ & $\begin{array}{l}\text { 1. } 23 \\
2.11 \\
1.57 \\
1.36 \\
1.63\end{array}$ & $\begin{array}{l}1.55 \\
1.98 \\
2.46 \\
1.62 \\
3.40\end{array}$ & $\begin{array}{l}2.02 \\
1.93 \\
2.58 \\
2.03 \\
2.75\end{array}$ & $\begin{array}{l}0.77 \\
2.1 .9 \\
.91 \\
2.50 \\
1.90\end{array}$ & $\begin{array}{r}1.77 \\
1.61 \\
3.01 \\
.04\end{array}$ & $\begin{array}{l}.54 \\
.70\end{array}$ & \begin{tabular}{l}
$14.34+$ \\
20.16 \\
\hdashline $13.27+$
\end{tabular} \\
\hline
\end{tabular}

Weather record at camp near Anthracite Ridge, Alaska, June 14 to Dec. 8, 1932 [Elevation 2,450 feet]

\begin{tabular}{|c|c|c|c|c|c|c|c|}
\hline & $\begin{array}{l}\text { June } \\
14-30\end{array}$ & July & Aug. & Sept. & Oct. & Nov. & $\begin{array}{c}\text { Dec. } \\
1-8\end{array}$ \\
\hline $\begin{array}{l}\text { Temperature }\left({ }^{\circ} \text { F.): }\right. \\
\text { Highest. } \\
\text { Lowest } \\
\text { Precipitation (inches) }\end{array}$ & $\begin{array}{r}70 \\
29 \\
2.46\end{array}$ & $\begin{array}{r}75 \\
31 \\
2.53\end{array}$ & $\begin{array}{r}65 \\
34 \\
2.44\end{array}$ & $\begin{array}{r}60 \\
21 \\
2.75\end{array}$ & $\begin{array}{r}49 \\
8 \\
2.33\end{array}$ & $\begin{array}{r}26 \\
-7 \\
0.63\end{array}$ & $\begin{array}{r}17 \\
-13 \\
0.31\end{array}$ \\
\hline
\end{tabular}

The winter of 1931-32 was locally considered to be a season of unusually heavy snowfall, and the following summer to be unusually wet, with many cloudy days. The rain came mainly as drizzles, so that although the total amount was not great, the undergrowth 
was kept wet most of the time, and the moisture in the winds from Cook Inlet often condensed into fog along the upper slopes of Anthracite Ridge.

\section{VEGETATION, ANIMAL LIFE, AND HABITATIONS}

Spruce timber covers most of the district up to an elevation of about 3,000 feet, or practically to the foot of the ridge. On the lower slopes there are willows, alders, and cottonwoods along the streams, and farther west there are some areas of birch; but south of the ridge, fire about 1920 killed most of the birch trees along with much spruce. Blueberries and several other kinds of berries are to be found along the lower ridges. Above timber line there is a cover of buck brush, grasses, and mosses, but above about 4,000 feet the slopes of the ridge have only a scanty growth of grass, mosses, and other low plants.

In the spring and early summer mountain sheep and occasionally goats range on the ridge, and sometimes they return later in the season. Black bears feed in the zone between the ridge and the river when the berries are in season, and an occasional brown bear has been seen in the district. $\mathrm{A}$ fer moose and woodland caribou have been seen in the wooded portions. During the last few years small animals have been scarce. Possibly this is due to the fact that the rabbits were nearly exterminated by some disease, apparently similar to tularemia, several years ago, and in 1932 were only beginning to reappear. Their disappearance seems to have caused the fox, lynx, and other predatory animals, including the coyote, which had extended its range into this region within the past 15 years, to migrate elsewhere.

Ptarmigan and spruce hens were scarce in 1931 but fairly plentiful in 1932 ; and tree squirrels, parka squirrels, and weasels were becoming more common. Some of the lakes and larger creeks contain trout, but not in sufficient abundance to be important as a food supply. Small bands of ducks occasionally visited the water bodies. A few magpies, Canada jays, and smaller birds stayed in the district throughout the year. In the early summer robins and several other migratory birds nested there. A few hawks of both large and small species were seen.

In 1932 about half a dozen families were living at Chickaloon, but there were no permanent inhabitants near Anthracite Ridge. The trail from Chickaloon to the Nelchina mining district, 60 miles to the east, passes along the slopes south of the ridge; and two cabins on this trail, one near Boulder Creek and one near Kutzkatna Creek, were used as stopping places by travelers. At Tatondan Lake, in the southeast corner of the district, there was a trapper's cabin. 


\section{STRATIGRAPHY}

\section{LOWER JURASSIC}

The oldest rocks in the region whose age is definitely known consist of bedded volcanic materials (breccia, agglomerate, and tuff) and other volcanic rocks classed as greenstone and quartz porphyry. Some of these bedded materials contain fossils, in places of marine animal forms, in places of plant forms, both of which identify the deposits as Lower Jurassic. These rocks were named the "Talkeetna formation" by Martin, ${ }^{11}$ because of their prevalence in the Talkeetna Mountains, of which Anthracite Ridge is a southernmost portion. On the crest of the ridge the volcanic rocks are exposed in only one prominent ledge; but they form much of the rugged country immediately to the north, where they are in places colored yellow and brown by iron oxides. On the south side of the Matanuska River the volcanic materials form much of the lower slopes of the Chugach Mountains.

\section{LATE JURASSIC (?)}

Granitic materials that form part of the slopes of the Chugach Mountains (pl. 5, A) on the south side of the river seem to have been intruded into the older and more altered series of rocks that form much of the slopes. The granitic rocks are mainly of the variety known as quartz diorite, which contains plagioclase (sodalime feldspar) instead of the orthoclase (potash feldspar) of a true granite. From their relation to the Lower Jurassic rocks these granites are considered to be probably of late Jurassic age.

\section{UPPER CRETACEOUS}

Within the upper Matanuska Valley region the Upper Cretaceous series is represented by black shale and indurated sandstone and conglomerate, which in a few places contain marine fossils. From their prominent exposures in the area these deposits were named by Martin ${ }^{12}$ the "Matanuska formation." They form part of the bluffs on the south side of the river, and prominent bluffs on the north side from 3 to 12 miles above the mouth of the Chickalson River. 'To the east they cover large areas north of the river, and they also form a part of Anthracite Ridge.

The detailed work of 1931 and 1932 found that the Upper Cretaceous rocks probably are exposed there in two bands, where brought to the surface by folding and faulting (pl. $5, B$ ). During

\footnotetext{
${ }^{11}$ Martin, G. C.. The Mesozoic stratigraphy of Alaska: U. S. Geol. Survey Bull. 776, p. 219, 1920.

${ }^{12}$ Idem, p. 317.
} 
the earlier studies fossils were found in the upper Cretaceous beds at several places in the bluffs bordering the river, and also on the north side of Anthracite Ridge; and Martin found a few Upper Cretaceous fossils on the south side of the ridge, near Purinton Creek. Lists of the species found have been published. ${ }^{13}$ In 1932 Upper Cretaceous fossils were found only on the upper part of Chikootna Creek, along whose ravine numerous fragmentary specimens were gathered, where they and the hard limy masses containing them had concentrated from the weathering shale. A few ammonites were obtained directly from the shale. The following species were identified by J. B. Reeside, Jr.:

U. S. Nat. Museum no. 16398. Headwaters of Chikootna Creek, Anthracite Ridge, Alaska :

Acila cf. A. truncata Gabb.

Yoldia? sp.

Grammatodon sp.

Inoceramus cf. I. whitneyi Gabb.

Inoceramus sp.

Ostrea sp., a very simple form.

Pholadomya sp., a fragment.

Oligoptycha cf. O. obliqua (Gabb).

Anisomyon sp.

Gastropods, several undetermined forms.

Dentalium sp., fragments.

Baculites cf. B. anceps Lamarck.

Ptychoceras sp.

"Heteroceras" cooperi Gabb.

Bostrychoceras? sp.

Phylloceras ef. P. ramosum (Meek).

Desmoceratid ammonite, undetermined.

Puzosiid ammonite, undetermined.

Parapachydiscus, 2 sp.

Gaudryceras sp.

This collection belongs in the late Upper Cretaceous (Senonian), but I hesitate to assign specific names to the forms present until much more work can be done. In all probability most of the species deserve new names.

\section{TERTIARY}

\section{CHICKALOON FORMATION}

Unconformably overlying the marine Upper Cretaceous beds are extensive fresh-water deposits of Eocene age. These deposits cover most of the valley of the Chickaloon River and hence were named by Martin ${ }^{14}$ the "Chickaloon formation." Measurements of their exposed thickness indicate fully 2,000 feet of beds.

\footnotetext{
${ }^{2}$ Capps, S. R., Geology of the upper Matanuska Valley, Alaska, with a section on the ignecus rocks by J. B. Mertie, Jr. : ¿־. S. Geol. Surver Bull. 791 , pp. 37-39, 1927.

"Martin, G. C... and Kat\%, F. J., Geology and coul fields of the lower Matanuska Valley, Alaska : U. S. Geol. Survey Bull. כ00, p. 42, 1912.
} 
The Chickaloon beds contain abundant fossil plant leaves, of the same species that are found in the Kenai formation in the western part of Kenai Peninsula, on lower Cook Inlet. The Chickaloon is thus considered to be of the same geologic age as the Kenai, which is classed as upper Eocene. The Kenai beds are soft, poorly consolidated sands and clays, dipping at low angles, and the coal beds within them are all lignitic, whereas most of the beds of the Chickaloon formation are consolidated, and all the coals are of higher rank than lignites, ranging from bituminous to anthracite. The relation of the Chickaloon formation to the Kenai formation has not been satisfactorily determined; for although the plant fossils indicate that they are of approximately the same geologic age, the Chickaloon beds have been much more folded, faulted, and consolidated than the Kenai beds.

The Chickaloon formation consists of a rather monotonous succession of shale, sandy shale, sandstone, grit, and conglomerate, deposited so irregularly that much of the material seems to have been laid down by streams flowing in from different directions. All the beds change in character within short distances along the bedding. The shales are mainly dark gray and poorly bedded. In many places they weather with conchoidal fracture. At many horizons there is so much carbonaceous matter that they are nearly black. Fossilbearing layers still retain the carbonaceous matter of the leaves and other vegetal fragments as coaly films. The sandy shales are chiefly feldspathic, with relatively little quartz. At some horizons they contain abundant flakes of brown mica. In a few localities the deposits are laminated, but for the most part they are somewhat cross-bedded. The sandstones are gray to yellowish in tone and are feldspathic, with not much quartz. They are fairly well consolidated. In the basal part of the formation there are thick-bedded sandstones that have a greenish-gray tone, due to the presence of chlorite. The grits consist largely of angular fragments of quartz and feldspar. The conglomeratic beds contain well-rounded pebbles, mainly of quartz and chert and less than half an inch in dimensions. These coarse-grained beds are not limited to any portion of the section but seem to be distributed irregularly through the entire formation. In the lower part of the formation there are several coal beds.

The basal beds of the Chickaloon where exposed along the central part of Anthracite Ridge have some characteristics not observed elsewhere. In some places there is a poorly defined pebbly sandstone, which may represent a basal conglomerate. West of Chikootma Creek this sandstone contains well-rounded pebbles of quartz and chert as much as an inch in diameter. For half a mile east of the creek this horizon seems to be marked by a sandstone containing angu- 
lar pebbles of shale, presumably Upper Cretaceous shale. A thin zone of sandy shale at about this horizon contains worm tracks. At one horizon in the sandstone there are scattered discoidal concretions of calcareous sandstone 1 to 2 feet in diameter.

Along the eastern part of the ridge there is a whitened band 30 to 50 feet thick, as shown on plate 6 . This band is thickest in its eastern portion, where it is dominantly a conglomerate with wellrounded quartz pebbles half an inch or less in diameter. Thence westward the material grades to prevailing coarse sandstone, with whitened hardened shale in the lower portion. This shale in some places contains well-preserved plant impressions. The band terminates on a ridge where the beds are caught in an overturned synclinal fold. Farther west the beds at this horizon have been removed by erosion. Although the whitening is confined to a definite zone, the beds within this zone are not all equally bleached, so that the apparent thickness of the band varies somewhat. The hardened plantbearing shale is similar to the baked shale known as porcelanite, which is found in many coal regions adjacent to beds that have been on fire, except that it has been only whitened and not heated sufficiently to become reddened. Nowhere in the district was evidence found that any of the coal beds had been on fire. Such natural burning is in other regions limited to lignitic or subbituminous coals containing more volatile matter than the coals of this district. Similar whitened shales were found at several other places in the district, adjacent to thick intrusive sills; but no evidence was found of an extensive sill which might have baked the shale of the whitened band. The whitening also of sandstone and conglomerate overlying the shale is distinctive; and close examination suggests that some bleaching action, possibly by mineralized hot water circulating through this porous zone, has taken place.

In those portions of all the diamond-drill holes where fractured and slickensided rock was encountered, veins of calcite were common in the seams. In a few places there were noticeable amounts of pyrite, as very small crystals, and probably finely divided pyrite is disseminated through much of the shale.

In three places-at a depth of 705 feet in the northwest drill hole, at 422 feet in the southwest $\mathrm{A}$ drill hole, and at 1,525 feet in the southeast drill hole-seams of gray-brown flaky clay half an inch to 2 inches thick were noticed. The material was examined microscopically by Clarence S. Ross, of the Geological Survey, who reported as follows:

The shalelike material from Alaska shows clear evidence of derivation from a volcanic ash. A large part of this was originally a glassy material with a distinct pumice structure but is now completely altered to a bentonite. 


\section{GEOLOGY OF ANTHRACITE RIDGE COAL DISTRICT, ALASKA}

Associated with this there was originally a small amount of feldspar and a large amount of biotite that formed phenocrysts in a glassy ash. The biotite has been completely altered to a slightly brownish type of kaolinite that evidently contains some iron. Associated with this is a notable proportion of carbonaceous material.

The complete alteration of the glassy portion of the ash to bentonite and the biotite to kaolinite in a material that evidently has not weathered under the profound oxidizing conditions characteristic of the usual kaolinization process is unusual and requires an explanation. Howerer, it is known that some kaolinitic materials have also formed in a swampy environment under the influence of humic acids. The presence of carbonaceous material with the bentonite probably indicates that the alteration of the biotite to kaolinite has taken place in a swamplike environment, and probably before deep burial by later sediments.

A principal point of interest is the rapid altermation of deposits shown by the diamond-drill cores and the irregularity of sequence in the beds. The greater part of the section is composed of shale and sandy shale, the coarser-grained sediments being very subordinate. These usually come in abruptly; although in some places the texture changes from fine through medium to coarse; more commonly it changes from fine directly to coarse. Deposition seems to have taken place rapidly, and the sediments are in part stream deposits that show much cross-bedding. Well-preserved plant remains are present in many layers of the shale and sandy shale; and from such fossil-bearing material, collected at several places in the region, numerous species of plants have been identified. Lists of such fossils are given in the reports by Martin ${ }^{15}$ and by Capps. ${ }^{16}$

Material collected at several localities and cores from the diamondclrill holes yielded numerous fossils, including some new species which are described in a report by the late Arthur Hollick. ${ }^{17}$

All the plant forms seem to be of Eocene age, and no appreciable change in the character of the flora was discernible in the collections from the drill holes, embracing sections as much as 1,700 feet in thickness.

\section{ESKA CONGLOMERATE}

On both sicles of the Chickaloon River 5 or 6 miles above its mouth the Chickaloon formation is overlain without apparent unconformity by massive beds of conglomerate, with minor lenses of coarse sandstone and thin beds of sandy shale. Farther west this formation is more extensive and was named by Martin ${ }^{18}$ the Eska

\footnotetext{
${ }^{15}$ Martin, G. C., and Katz, F. J., Geoloyy and coal fields of the lower Matanuska Valley, Alaska: L. S. Geol. Survey Bull. 500, pp. 49-52. 1912.

${ }^{16}$ Capps, S. R., Geology of the upper Matanuska Valles, Alaska, with a section on the igneous rocks by J. B. Mertie, Jr.: U. S. Geol, Survey Hull. 791, p. 44, 1927.

17 llolick, Arthur The Tertiary floras of Alaski : I. S. Geol. Survey Prof. I'aprer 1s2, 1936 .

18 Martin, G. C., op. cit. (Bull. 500), p. 52.
} 
conglomerate, from typical exposures on Eska Creek. In Castle Mountain, north of Chickaloon, a thickness of about 3,000 feet of this formation is exposed. The materials are fairly well indurated, the pebbles being mainly granitic and the matrix being sandy. In a few places fossilized fragments of wood have been found in the formation, but no coal beds. From its position overlying the Eocene deposits, the Eska conglomerate is questionably considered to be of Miocene age.

\section{INTRUSIVE ROCKS}

Prominent ridges that occupy considerable areas in the region between Chickaloon and Anthracite Ridge are covered by intrusive igneous rocks. Along the south side of Anthracite Ridge thick sills are prominent. In the district there are also many thin sills and dikes, from a few inches to 10 or 15 feet thick. All that were noted during the geologic work are shown on plates 2 and 3. Most of the sills are diabase, an intrusive rock composed chiefly of plagioclase feldspar, augite, and oxides of iron, including magnetite. The surfaces of some of the larger sills are in places vesicular or amygdaloidal, with patches of zeolites. A few of the minor sills and dikes are vesicular and probably consist of basalt.

Diabase sills are not confined to any particular portion of the Chickaloon formation. They were found at irregular intervals throughout the beds penetrated in the diamond-drill holes. The sills of about 2 feet or less in thickness are fine-grained rock, of uniform gray color. The upper and lower several inches of the thicker sills are also fine-grained gray rock, but this grades into coarse-grained material in the middle portions. 'The two kinds of rock from the sill penetrated at about 200 feet in the central drill hole were examined microscopically by J. B. Mertie, Jr., who found that the difference is chiefly in texture and that there has not been any appreciable segregation of the darker minerals in the middle portion of the sill. The coarse-grained diabase contained plagioclase of about the composition of labradorite, considerably altered to sericite and in part to chlorite; augite, more than half of which is altered to chlorite; and magnetite. The fine-grained rock was in texture more nearly a basalt. In it the plagioclase was almost unaltered, but the iron oxides were altered to hydroxides, and the remainder of the matrix was almost completely altered to carbonates. It is rather unusual to find deeply buried and presumably unweathered rock with its constituent minerals so greatly altered.

The west end of Anthracite Ridge is formed of a somewhat different type of igneous rock, classed as soda felsite; which contains prominent crystals of plagioclase. West of Anthracite Ridge the upper portions of Puddingstone Hill and Castle Mountain are 
composed of flows of basaltic lava which are probably of a somewhat later age than the diabase sills. As all the intrusive rocks and the lavas seem to be later than the Eska conglomerate, they have been considered to be probably of Pliocene age.

\section{QUATERNARY}

Portions of the slopes on each side of the Matanuska River are covered by glacial gravel, but within the area included on plate 1 , most of such deposits are very thin and hence have not been indicated on the map. In the northwestern part of the district, however, thick glacial deposits, probably forming a moraine, cover slopes north of Boulder Creek; and in the southeastern part, between Gravel Creek and the Matanuska River, there is a considerable area of terrace gravel of glacial origin. Along lower Muddy Creek there are large boulders and unassorted materials, indicating a thickness of 50 feet or more of glacial debris over a small area.

Scattered boulders and thin patches of gravel are to be found up to elevations of nearly 5,000 feet on the south face of Anthracite Ridge. At an elevation of 4,900 feet, on the crest of a spur ridge near Cascade Creek (on the east border of the area shown on pl. 2 ), there is a rounded granitic boulder about 2 feet in diameter. This was probably about the upper limit of the ice, for there is little evidence of glacial material higher on the slopes. Farther west but at an elevation of only 3,100 feet a similar, nearly spherical boulder caps the summit of the southernmost of three small ridges in the SE1/4 sec. 11, T. 20 N., R. 7 E. The bare surface of a diabase knoll just to the north shows numerous glacial scratches, trending westward down the valley. Although most of the hard-rock surfaces are weathered and spalled, similar scratches are still to be seen in a few other places. They were noticed on the southernmost crest of the diabase ridge near lower Purinton Creck, also several miles farther west, on the east end of a ridge that borders Rush Lake. Along the base of Castle Mountain there is similar evidence of glacial action up to an elevation of about 3,500 feet. Recent or postglacial deposits of appreciable extent are limited to the valleys of the principal tributary streams. These all have fairly steep gradients, and their materials are mostly cobbles and pebbles, with comparatively small amounts of sand and clay.

\section{STRUCTURE}

\section{UPPER MATANUSKA VAILEY}

The structure of the upper Matanuska Valley considered as a whole is that of a great block dropped between two faults, one along Anthracite Ridge and the other along the lower slopes of 
the Chugach Mountains. The main part of the area is covered by rocks of the Chickaloon formation, but the faulting has brought to the surface the Upper Cretaceous beds along the margins of the faulted zones; and a subsidiary though large fault brings Upper Cretaceous beds to the surface for several miles along the north side of the Matanuska River.

In the west the dropped area has been considerably folded and faulted. A steeply folded syncline that crosses lower Coal Creek passes in each direction into a fault; and similar steep folding accompanied by faulting has occurred near Chickaloon. This is the western portion of a large synclinal area which extends northeastward ulong the south side of Boulder Creek Canyon, approximately along the Chickaloon-Nelchina trail, and swings south of east along the flank of Anthracite Ridge.

\section{ANTHRACITE RIDGE DISTRICT}

The Anthracite Ridge district is folded on the east and west into a broadly synclinal basin. The detailed structure of the district, as worked out in 1931 and 1932, is shown on plates 2, 3, and 4. The major features are the northern fault, the northern belt of folding, the intermediate fault, the intermediate belt of folding, and the southern fault. All these structural features trend nearly parallel with the ridge.

The northern fault marks the border of the dropped block of the Matanuska Valley. Farther north, beyond the band of Upper Cretaceous rocks exposed by the faulting, are the older rocks that form the main portion of the Talkeetna Mountains. Along most of the front of Anthracite Ridge the fault is within the Chickaloon formation, but in the central part of the ridge the Upper Cretaceous rocks are exposed by subsidiary faulting or sharp folding. The contact of the two formations is plainly traceable westward from Chikootna Creek. In part this may be a fault contact; but in some places, notably on the east bank of Chilkootna Creek, it seems to be the unconformable contact at the base of the Chickaloon beds, which dip $40^{\circ} \mathrm{S}$. and rest directly on black fossil-bearing Upper Cretaceous shales, which $\operatorname{dip} 60^{\circ} \mathrm{S}$.

The northern belt of folding is well exhibited along the middle slopes of Anthracite Ridge, in an area cut by deep ravines. Several thin sills of diabase that were folded with the sediments aid in showing the structure. This consists essentially of two minor anticlines, the limiting syncline on the north being overturned against the northern fault. This overturning suggests a thrust, but examination of the zone indicates that it involves only surficial beds and was 
probably produced by squeezing along the normal fault. The middle and southern synclines are open.

The structure near the central part of the ridge is shown in cross section $C-C^{\prime}$, plate 4, and in the photographs reproduced in plate 6 . Farther west the beds are more faulted, as shown in cross section $B-B^{\prime}$; and farther east the folding is more intense, as shown in cross section $D-D^{\prime}$.

The northern belt of folding is limited on the south by the intermediate fault. This is a prominent feature along the base of the central part of the ridge, and is marked by cliffs, over which the streams cascade ( $\mathrm{pl}$. 7, $B$ ). This fault seems to die out westward at about the limit of the principal areas of intrusive rock; and to the east it apparently passes into an anticline at the east end of a thick diabase sill. Its maximum displacement seems to be near the place where Purinton Creek cascades down the fault cliff, where a throw of about 400 feet is indicated.

The intermediate belt of folding occupies the slopes extending from the base of the ridge southward nearly to the bluffs along the river. As a whole this area is synclinal in structure and is the eastern continuation of the syncline that extends up the basin of Boulder Creek from Chickaloon, but in detail the belt along the front of Anthracite Ridge contains minor folds and faults. South from the ridge the dip is uniformly southward as far as the zone where the streams from the central part of the ridge turn westward in their courses. This zone marks a synclinal axis, limited on the west where the beds turn to an easterly dip. Eastward the synclinal axis dies out or is offset and continues as a fault, whose trace is well shown where it crosses Tukmakna and Cascade Creeks. Farther east this fault seems to die out along the base of a ridge of intrusive rock west of Winding Creek. Thence eastward the line of weakness continues as an open synclinal axis to Muddy Creek. The east end of this syncline, like the west end, is formed by the upturning of the beds.

Within the intermediate zone, south of the central portion of the ridge, the beds rise from the synclinal axis to a minor anticline in the NW1/4 sec. 24, T. 20 N., R. 7 E. This is apparently the northeast extension of an upward fold that is indicated in the ridges of intrusive rock in sec. 23. The crest of this small fold is well shown at its northeast end by several tilted beds of conglomeratic sandstone. On both flanks of the fold beds of coarse sandstone, grit, and conglomerate form small, narrow ridges. They are lenticular, and individual beds do not persist far. These hard ledges make plain the structure, dipping south to a flat syncline whose axis crosses Cascade Creek in the southern part of sec. 19, T. 20 N., 
R. 8 E. There are apparently 10 or 12 such beds on the south flank of the fold, though there may be some repetition by slice faulting. Farther south, where the beds are steeply upturned along Conglomerate Creek, there are seven prominent beds. About half a mile farther east this synclinal axis is not so evident where it crosses Winding Creek, but it is suggested by the marshy topography and the shallow stream channel across gravelly bench land. Still farther east the continuation of this broad synclinal fold is indicated by the dip of the beds exposed along Muddy Creek.

The southern fault zone, which bounds the dropped block constituting most of the district, is strikingly shown by the steep north front of the ridge of Upper Cretaceous rocks just west of lower Purinton Creek. The east end of this ridge forms a prominent bluff, as shown in plate $5, A$. This was caused by a cross fault, whose influence farther north is shown by several large landslides in the gorge of Purinton Creek and by nearly vertical dips in the beds at the bases of these slides.

Where the fault in its eastward course crosses Conglomerate and Cascade Creeks it is well shown by the steep dips and contorted attitudes of the beds. To the west the vertical displacement along the fault is probably several hundred feet. This lessens eastward. At Winding Creek it seems to be only 20 or 30 feet, and it was not recognized where the extension of the fault would cross the bluffs that border the Matanuska River.

The eastward change in the character of the folding and faulting in the district is indicated in the four cross sections of plate 4.

The structure as worked out on the sedimentary beds shows that the large areas of diabase in the district belong at several horizons. The thick sills along the base and flank of central Anthracite Ridge are considerably lower, stratigraphically, than the ridges of diabase between which Purinton Creek flows in the south-central part of the district. Probably there has been some faulting along the prominent southward-facing escarpments of these ridges and perhaps also where Purinton Creek passes between them; but the northern borders of these intrusive masses dip at angles of only $20^{\circ}$ or $30^{\circ}$ beneath the Chickaloon beds. At places along this northern contact the sandstone and shale have been baked and whitened for a thickness of fully 30 feet. The gorge of lower Purinton Creek has been cut in beds that underlie these intrusive rocks. To the south the diabase splits into a number of thin sills.

In the eastern part of the district the several areas of diabnse are probably at three horizons in the Chickaloon formation.

The six large areas of diabase in the Muddy Creek area all seem to be of approximately the same horizon and are probably portions 
of one great sill, somewhat folded and faulted. The laccolithic mass of Strelshla Mountain is considerably lower stratigraphically, but the thick sill north of it, high on the ridge, is several hundred feet higher in the formation than the other large sills.

\section{GEOLOGIC HISTORY}

The Matanuska River is nearly 100 miles long from its source in the ice fields of the Chugach Mountains to tide water at Cook Inlet. The earliest evidence that this valley region was once an arm of the sea is that furnished by the rocks of the Talkeetna formation, which contains fossils of Lower Jurassic age. In some places these rocks contain plant remains, and in other places they carry fossils of marine mollusks, showing that the region was in part covered by fresh water and in part by salt or brackish water. Long after their deposition and presumably after a period of uplift, these beds were intruded by granitic rocks, probably in late Jurassic time. During the Lower Cretaceous epoch, parts of the region northwest of the Matanuska Valley were below sea level, and thick deposits of limestone were formed.

During Upper Cretaceous time also the Matanuska Valley region must have been below sea level, for the deposits of that period are of sandstone and shale, which are shown by the fossils in them to have been deposited in salt water, probably an extension of the present Cook Inlet. The region was later uplifted but not much folded, and there followed a long interval of erosion. During Eocene time in the middle and lower Matanuska region deposits of the Chickaloon formation of irregularly bedded shale, sandy shale, sandstone, and grit were laid down in an extensive fresh-water basin. The recurrence of marshy conditions during early periods of the deposition formed coal beds of moderate extent in some parts of the basin.

Probably at the end of the Eocene the region was moderately uplifted, and in the following period of quiescence thick deposits of conglomerate were laid down in the lower part of the valley. This is the Eska conglomerate, which is questionably considered to be of Miocene age. Later, probably in Pliocene time, igneous rock was intruded into the sedimentary deposits. The region was afterward greatly faulted, and in some portions the rocks were much folded. The thin dikes and sills were folded and faulted, together with the sandstones and shales; but locally the thick masses of igneous rock, although faulted, seem to have been strong enough to resist close folding. Layers of basaltic lava, which probably represent a somewhat later period of flow, unconformably overlie the Eska conglomerate on some of the higher areas, notably on the crests of Castle Mountain and Puddingstone Hill. 
The present details of the Matanuska Valley have probably been formed chiefly since Pliocene time by the ordinary processes of erosion and weathering. After the main period of erosion the valley was deeply filled with ice; and after a period of relative stability there was uplift and a climatic change, which caused the ice to melt and the streams to cut deep channels. The Matanuska River then cut its present valley, which is half a mile to 1 mile in width and is deeply entrenched in the older valley. Its larger tributaries have also cut deep ravines: Boulder Creek in its upper portion still flows in its older upland valley, but its lower portion has cut a gorge through which the stream descends 1,300 feet in the 5 miles between Boulder Flat and the Chickaloon River. The Chickaloon is also deeply entrenched in its lower portion. The small streams that drain Anthracite Ridge likewise exhibit evidence of active cutting in their lower courses. Their head waters have cut deep ravines in the upper slopes of the ridge; farther down they open onto lower slopes acress which the channels are shallow; in their lower portions the streams flow down to the Matanuska River in deep ravines.

Between 1 and 2 miles above Chickaloon there are seven welldeveloped terraces cut in the reworked gravel of the valley sides. These terraces apparently mark successive levels of the valley floor, either as the stream cut down through a hard band of diabase that partly dammed its course or as the gradient of the stream was increased by successive small uplifts of the area.

\section{COAL}

\section{DEPOSITS IN MATANUSKA VALLEY}

Coal is the only mineral deposit of commercial importance in the region, for the Tertiary and Upper Cretaceous rocks of the Matanuska Valley contain no metallic mineral deposits of value, and the intrusive igneous sills and dikes are not appreciably mineralized by veins. A test well for oil was drilled in 1924-30 to a depth of 1,465 feet, about 2 miles west of Chickaloon, on a showing of coal gas; but the possibility of the presence of petroleum in either the fresh-water Eocene beds or the marine Upper Cretaceous deposits of the valley is exceedingly remote.

The presence of coal in the Matanuska Valley was learned from the Indians by prospectors as early as 1894 . Some of the outcrops were seen by Mendenhall ${ }^{19}$ during his exploration of 1898 .

The Chickaloon formation, which covers much of the valley from Moose Creek, about 10 miles east of Matanuska, to Packsaddle Gulch,

19 Mendenhall, W. C., A reconnaissance from Resurrection Bay to the Tanana River, Alaska, in 1898: U. S. Geol. Survey 20th Ann. Rept., pt. 7, p. 324, 1900. 
35 miles farther east, contains beds of coal in several areas. The westernmost exposures are in the valley of Moose Creek and in the north bank of the Matanuska River for a short distance below the mouth of Moose Creek. Farther west the Chickaloon formation is covered by thick deposits of gravel, and coal beds are not exposed.

In 1915 the principal coal-bearing areas of the valley were subdivided by the United States Bureau of Mines into 19 leasing units, and several permits were granted for coal prospecting. In 1916 the Doherty or Pioneer mine was opened on the west side of Moose Creek about three quarters of a mile above its mouth. It was developed by a drift tunnel and shaft on a 3 -foot bed of coal. The product was hauled by a narrow-gage tramway 3,000 feet to bunkers at a railroad siding near the mouth of the creek and sold to the railroad and in Anchorage. The coal was dirty, however, and the mine was shut down after 3 months' operation.

The Baxter mine, $4 \frac{1}{2}$ miles above the mouth of Moose Creek, produced coal from December 1917 to April 1918 from an 11-foot bed exposed on the side of the creek, and the coal was sledded down the valley to the railroad. Later development showed the coal bed to be faulted, and although two other beds about 3 feet thick were found a few feet below the main bed, lack of capital and of skilled supervision of the prospecting caused the closing of the mine for a time. It was reopened in 1921 and produced small amounts of coal during the next few years, but operations ceased in 1925 .

Coal showings at several other places along Moose Creek were also prospected during these years, but successful development was hindered by the faulted condition of the beds. At the Rawson mine and at the property of the Alaska Matanuska Coal Co., respectively 2 miles and $21 / 4$ miles above the Baxter mine, tunnels were driven and considerable development work was carried on. Some coal was produced from the Rawson mine until late in 1926 and from the Alaska Matanuska through 1929.

In 1925 a narrow-gage railroad was extended up the Moose Creek Valley to these upper properties. The Premier mine of the Alaska Matanuska Co., three-quarters of a mile below the Baxter mine, was also put on a producing basis, a large part of the coal being purchased by the railroad. In 1926 the railroad was made broad gage to the Premier, and this became the principal mine in the Moose Creek area. There are five principal beds of coal, averaging 3 to 6 feet in thickness, in a series of shale and sandstone about 100 feet thick. The workings pass under Moose Creek, and late in 1933 water broke in, flooded the mine, and caused it to be abandoned.

During the later part of 1932 the Wishbone Hill Coal Co. produced a small amount of coal from workings on the old Rawson 
property. In 1934 these workings were taken over by the New Black Diamond Coal Co.

Along Eska Creek, which is about 5 miles east of Moose Creek, coal beds are exposed at intervals in the banks on one side or the other of the stream. In January 1917 the Eska Creek Coal Co. began development work, but in June of that year its property was purchased by the Alaska Engineering Commission in order to assure a fuel supply for the railroad, and the mine was operated by the Government during the next $\approx$ years. Throughout 1918-20 it produced 100 to 150 tons daily. In October 1921, shortly after the opening by private enterprise of the Evan Jones mine, $11 / 2$ miles to the west, the Eska mine was closed, but it has been kept in condition to produce on short notice in case of failure of the private enterprises. During the later part of 1922 it was opened for several weeks while the Evan Jones mine was closed on account of fire. At Eska there are six coal beds, in two groups of three beds each, separated by nearly 300 feet of sandstone and shale. The beds that have been developed are on the north limb of an open syncline. The Evan Jones mine has been opened on a group of three beds, about 7, 3, and 2 feet thick, several hundred feet higher in the Chickaloon formation than the coal beds of Eska.

On Young Creek, 7 or 8 miles east of Eska Creek, two thin coal beds are exposed about $31 / 2$ miles above the junction of the stream with the Kings River, and at least 10 beds are exposed in a gulch 2 miles farther north. Some prospecting was early done on these beds, but no mine was opened.

Along the Kings River about 8 miles above its mouth coal beds are exposed for about a quarter of a mile. There are several coal beds 1 to 3 feet thick and one or two beds that are considerably thicker. These were early prospected, but the coal was found to be much crushed and also intruded by igneous rocks. In 1920-21, in connection with exploratory work by the United States Navy, two small tunnels were driven on the most promising bed, which was 9 feet thick where exposed. One tunnel encountered intrusive rock 70 feet in from the surface and found the coal to be coked and destroyed. The other entry was started 100 feet farther down the dip and at 200 feet lost the coal at a fault which replaced the coalbearing formation with rocks of Upper Cretaceous age.

In the area between the Kings River and Chickaloon, a distance of about 5 miles, trenches and pits that were dug to trace the structure uncovered 19 bituminous coal beds $2 \frac{1}{2}$ to 9 feet thick, but intrusive rocks also persist with the coal. Hill ${ }^{20}$ states that none of the

\footnotetext{
${ }^{20}$ Hill. W. P. T., Final report of the Navy Alaskan Coal Commission to the Secretary of the Navy, p. 52, 1922 (manuscript).
} 
beds uncovered in this area could be definitely correlated with any of the coal beds exposed either on the Kings River or at Chickaloon.

At Chickaloon several beds of coal are exposed for a distance of half a mile in the bluffs along the north side of the Chickaloon River. As early as 1905 there was some prospecting here. In 1913 about 1,100 tons was taken out under the direction of the United States Bureau of Mines and sledded to the coast during the winter. This was shipped to Seattle, and 586 tons was used in a steaming test of the U. S. S. Maryland and found to be "suitable in every respect for use in the naval service." ${ }_{21}$ In June 1917, when the Alaskan Engineering Commission took over the Eska mine, it also undertook the continuation of private exploration at Chickaloon; and on the completion of the railroad to that point in October, some coal was shipped for the railroad use. During the next 2 years about 8,000 tons of coal was produced incidentally to the prospecting work. Meanwhile the Navy had become interested in developing a fuel supply on the North Pacific coast, and on July 1, 1920, the Navy Alaskan Coal Commission took over the exploratory work at Chickaloon. Work was continued until the end of April 1922, when the property was shut down. It was temporarily reopened a few months later in order to complete a shipment of 5,000 tons for steaming tests by the Navy. Tests of coal from the Bering River field were made at the same time.

One lot, 600 tons of Bering River coal, and another lot, 5,000 tons of Matanuska coal, were tested by the Jason, the New York, and the Tcxas. It was found from these tests that while Alaskan coal may, under certain circumstances, be used by naval vessels, it is not generally satisfactory for this purpose. $^{22}$

A total of about 25,000 tons was produced at Chickaloon from 1913 to 1922 . In the bluff at this place nine tumnels and one slope were driven, and one tunnel was driven half a mile farther east, to crosscut coal beds exposed beside the river. In addition, much trenching and pitting was done in the area northward to the base of Castle Mountain. A diamond-drill hole was put down 3,400 feet north of the bluff to a depth of 1,345 feet without reaching the coal beds. The presence of 10 or more coal beds was proved by the tunnels, and the slope followed down on the thickest one, bed 8. This extended nearly vertically, with a thickness of 10 to 12 feet, to a depth of 820 feet, where it was squeezed and faulted out. The three other principal beds, nos. 1,5 , and $\mathrm{X}$, had average thicknesses, respectively, of about 4,6 , and $41 / 2$ feet where cut by the tunnels. The beds are in three groups, separated by sandstone and shale, in a series 600 to 750 feet thick.

a 64th Cong., 1st sess., S. Doc. 26, p. 9, 1915.

${ }^{22}$ Report of the Secretary of the Navy for 1923, p. 326, 1924. 
The underground work showed that the coal beds lack continuity. They thicken and thin irregularly and grade into beds in which the carbonaceous material forms only a small part. This character is due partly to folding and faulting but chiefly to the nature of the original deposits. The vegetable matter apparently accumulated in small basins along valley bottoms, giving recurring transition from clean coal within the basins to dirty coal or even clay on the rims. Cross faults displace the beds, and faults along the bedding produce squeezing and irregular thickening of the coal, and local zones of crushing. Westward the coals become thinner or are represented by carbonaceous shales.

During 1921-22 the Navy did some prospecting work on coal beds that crop out about 2 miles south of Chickaloon, on the east side of Coal Creek. Work in this area consisted in the driving of two tunnels near the creek and the sinking of numerous pits and the drilling of eight diamond-drill holes on the bench land east of the creek. Three main coal beds were found, the Spalding, Olsen, and Miller, respectively about 4, 3, and 6 feet thick; but they are considerably broken and in places intruded by igneous sills, which have locally coked the coal. About 1,300 tons of coal was produced incidentally to the prospecting; but this work was discontinued, as the amount of minable coal was found to be insufficient to warrant further prospecting or mining. A small amount of underground exploration was done about 3 miles east of Coal Creek, where coal beds are exposed in bluffs that border the Matanuska River. These beds were round to be of little commercial value, as they are cut off to the sonthwest by a fault, and to the north and east they are partly coked by igneous sills.

In 1925 the Coal Creek mine was opened by Ross S. Heckey on the west side of the creek, on the extension of beds earlier prospected by the Navy. The coal is semibituminous and of good quality for blacksmith use. During $1925-30$ about 1,650 tons was produced. Much of this was sold to the railroad, which converted it into coke in an oven at Anchorage and used the product in the foundry of the railroad shops.

About 1 mile west of Chickaloon work was undertaken late in 1917 by the Chickaloon Coal Co., and during the next year three tunnels were driven and two core holes were drilled. Several thin coal beds were penetrated by the tunnels; but the work showed that the coal beds of Chickaloon thin toward the west and are not of great commercial value. No production was made from this property.

East of the Chickaloon-Coal Creek area there are no further evidences of coal until the Anthracite Ridge district is reached, whose coal deposits are described in detail in the following pages. 
Coal on Hicks Creek has been reported, but the showings there are believed to be black shale in the Upper Cretaceous beds.

The coal beds of Moose Creek and the Evan Jones mine are in the upper part of the Chickaloon formation, not far below the Eska conglomerate, which covers the higher slopes and forms most of Wishbone Hill, lying between the two coal areas. The coals of the Eska mine are several hundred feet lower in the formation and may be near its base, for on the east side of the creek valley Upper Cretaceous beds are exposed, against which the coal-bearing beds of Eska are faulted. Sufficient detailed work has not been done to determine the position of the coals of the Young Creek and Kings River area and those of Chickaloon and Coal Creek, with respect to each other and to the coals farther west. At Chickaloon the coal is low in the formation, but there seems to be at least 2,000 feet of Chickaloon beds below the coal and an equal amount between the coal and the overlying Eska conglomerate.

The coals of Moose Creek and Eska are bituminous, their content of fixed carbon being about 46 percent and volatile matter 37 or 38 percent and the fuel ratio about 1.2. Analyses of samples from Young Creek and the Kings River show them to be of somewhat higher rank, with an average fuel ratio of about 2.1 to 2.9. The coals of Chickaloon and Coal Creek rank as semibituminous, with an average fuel ratio of about 3.3. Still farther east, in the Anthracite Ridge district, semianthracite and anthracite are found, though most of the coals of this district are bituminous and semibituminous.

Because of the seeming progressively higher rank of the coals eastward up the valley, there is some ground for the hypothesis that there has been progressively greater metamorphism of the coals eastward, due to increased folding and faulting and perhaps increased pressure by great thicknesses of overlying sediments. When the coal beds are examined in detail, however, so many exceptions to this hypothesis are found that it seems probable that much of the change to coals of higher rank may be of local nature, due to localized effects of folding, faulting, and intrusion by igneous rock. The relatively high rank of the Chickaloon coal is, however, considered by Hill ${ }^{23}$ to be due primarily to severe dynamic metamorphism; intrusive rocks have locally coked the adjacent coal, but the coal beds as a whole have been unaffected by the sills and dikes.

\section{DEPOSITS OF ANTHRACITE RIDGE DISTRICT}

CORRELATION

The outcrops of coal in the Anthracite Ridge district may for convenience be grouped into those of the northern area, along the cen-

${ }^{2}$ Hill, W. P. T., Final report of the Navy Alaskan Coal Commission to the Secretary of the Navy, p. 49, 1922 (manuscript). 
tral part of the ridge; the eastern area, in the basin of Muddy Creek; and the southwestern area, along lower Purinton Creek. Exposures of coaly shale along lower Cascade Creek may be considered as forming a fourth but minor area. The outcrops are numbered on plates 2,3 , and 8 .

So far as the evidence justifies, the coal outcrops have been connected, on plates 3 and 8 , to show the probable continuation of the beds. From this evidence and the geologic sections at several of the coal localities presented on plate 9 , it seems probable that there are three main coal-bearing zones, with a few thin beds and lenses higher and lower in the section. The highest and middle zones seem to be present in the northern area, the middle and lowest zones in the east ern area, and all three in the southwestern area. In the northern area the thick beds at localities 20 and 23, where 24 and 34 feet of clean coal was measured, and neighboring outcrops along the strike appear to be in the highest coal zone. The thickness of beds measured between localities 20 and 16 and between localities 22 and 19 shows that the coal beds of this northern line of outcrops lie about 100 feet below the highest coal of the area. They constitute the middle zone, as shown on plate 8 . To the south, the structure of the rocks and character of the beds indicate that coals of localities 24 to 33 belong to this middle zone. The two thin coal beds of locality 11 (see pl. 2) may represent the western extension of the two zones, and the coals of localities $8,9,10$, and 12 probably belong to one zone or the other. The detailed structure along the western part of the ridge is too obscure to render the coal horizon definite. The thickness of beds underlying the coal from locality 16 down to the Upper Cretaceous rocks was measured as about 500 feet. A measurement from the coal at locality 15 to the Upper Cretaceous rocks was as follows:

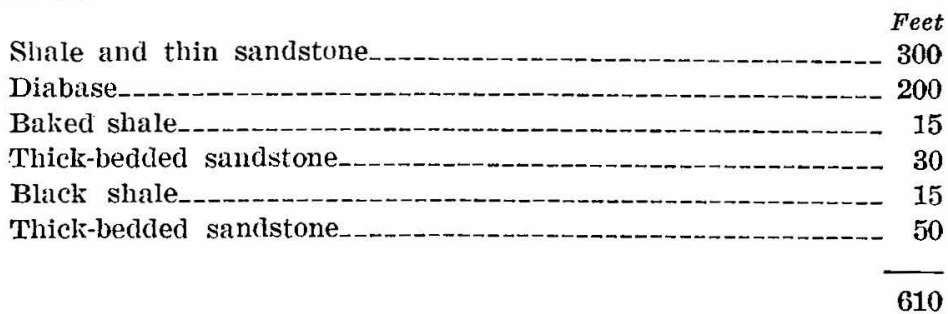

This measurement of about 600 feet from the highest coal zone to the Upper Cretaceous beds is in accordance with the measurement of about 500 feet from the middle zone to the Upper Cretaceous beds, as the two coal zones are about 100 feet apart.

Two measurements of the thickness of beds between the middle zone at locality 33 and the whitened band on the slopes above, showed a thickness of 850 to 900 feet of beds, or about 720 to 770 
O'Brien Creek, on the south side of the river, also belong to this middle zone.

The coals of the southwestern area, along lower Purinton Cresk, are distributed through nearly 400 feet of beds but seem to agree in their grouping fairly well with the three zones of the northern and eastern areas.

A fourth but minor area of carbonaceous deposits is indicated by coaly shales along Cascade Creek. From the evidence obtained on the structure and stratigraphy these beds are evidently high above the main coal beds of the district and probably are several hundred feet above the highest coal of localities 34,35 , and 36.

Data on the strike and dip of the rocks have been chiefly relied upon in the correlation of the coals of the three main areas as presented on plate 9 . The chemical character of the coals themselves was found to be of little help in their correlation, as there is so much local variation in the beds; and the thick diabase sills were not found to be satisfactory horizon markers. In the northern area these sills underlie the coal beds, but in the eastern area the principal sills overlie the coal-bearing beds. Along the middle portion of Muddy Creek the diabase is only a few feet above the highest coal bed; but the sill high on the ridge, near the headwaters of the creek, is several hundred feet above the coals. In the southwest, along lower Purinton Creek, the diabase is about 75 feet above the highest coal bed.

\section{OUTCROPS}

During previous studies by the United States Geological Survey in the district special attention was paid to the coal deposits, and the report by Capps ${ }^{24}$ summarized the information available in 1924 concerning them. The present report contains the additional information gained in 1931 and 1932 from surface examinations, tests pits and trenches, and diamond-drill holes. The following pages give information on the various coal outcrops examined in the Anthracite Ridge district; and in order to show the relation of this district to other coal areas farther down the valley, the coal beds of the Chickaloon, Coal Creek, and O'Brien Creek districts are also described briefly. The locality numbers refer to the numbered outcrops on plate 1. The locations of most of these are also shown on the detailed maps, plates 2 and 3.

T. 20 N., R. 5 E.

$1\left(\mathrm{SE}_{1} 1 / 4 \mathrm{NE} 1 / 4\right.$ sec. 25). The coal deposits and the prospect work done at Chickaloon have been described in preceding pages. At Chickaloon 10 or more coal beds are exposed in the 100 -foot bluff that borders the north side of

\footnotetext{
24 Capps, S. R., Geology of the upper Matanuska Valley, Alaska, with a section on the igneous rocks by J. B. Mertie, Jr.: U. S. Geol. Survey Bull. 791, 1927.
}

$53076-36-3$ 
the river. The coals seem to be in three groups of beds, in a series of shale and sandstone 600 to 750 feet thick, dipping steeply to the north and in some places overturned. The thicker coal beds are to the east. Westward some of them split into several thin beds, and others pinch out entirely.

Two analyses of coal from Chickaloon are tabulated on page 42, and a typical section of the formation is given in figure 2 for comparison with the coal-bearing series of the Anthracite Ridge district, of which sections are given on plate 9 .

\section{T. 20 N., R. 6 E.}

$2\left(\mathrm{NE}_{1 / 4} \mathrm{NW} 1 / 4\right.$ sec, 30$)$. About half a mile east of Chickaloon 4 coal beds are exposed in a bluff at the edge of the river; the largest is about 4 feet thick. As part of the exploration work by the Navy in 1920-22, a tunnel was driven at right angles to the beds, 200 feet west of their exposure; and the principal bed was prospected by a drift for 300 feet. A small amount of coal lias been obtained from the outcrop for local use,

$3(\mathrm{SE} 1 / 4 \mathrm{SE} 1 / 4 \mathrm{sec}$. 31). On the east side of the valley of Coal Creek about three-quarters of a mile above its mouth, coal beds are exposed, dipping steeply south. In 1921-22 these beds were prospected by the Navy Alaskan Coal Commission, as described in the preceding pages. A section of the coalvearing beds is given in figure 2, and an analysis of coal from the principal bed on page 42. The structure is that of a sharp syncline, passing at the east and west into a fault and locally broken by minor faults. The coal beds have also been locally altered by intrusive sills of igneous rock.

$4(\mathrm{SW} 1 / 4 \mathrm{SE} 1 / 4$ sec. 31). On the west side of Coal Creek, on the extension of beds prospected by the Navy, a mine was opened in 1925 by Ross S. Heckey on a bed containing 18 inches of minable coal of good quality for blacksmith use. The bed dips steeply and is overlain at a distance of a few feet by a sill nf igneous rock.

T. 19 N., R. 6 E.

$5\left(\mathrm{NW}^{1 / 4} \mathrm{NW} 1 / 4\right.$ sec. 5$)$. On the east side of Coal Creek about half a mile above the Coal Creek mine two beds of coal 5 feet and $11 / 2$ feet thick are exposed, dipping $65^{\circ} \mathrm{N} .25^{\circ}$ W., associated with several other coal beds only a few inches thick. The beds were prospected a number of years ago, but no coal was produced commercially. They are on the south limb of the syncline, approximately at the same horizon as the beds farther downstream, which are on the north limb of the syncline.

T. 20 N., R. 6 E.

6 (SW1/4NE1/4 sec. 33). In bluffs on the south side of Matanuska River 2 niles above the mouth of Coal Creek beds are exposed dipping $45^{\circ} \mathrm{S} .30^{\circ} \mathrm{E}$, which include three beds of coal of commercial thickness. Sections measured at two places in this bluff are given in figure 2, and the analysis of a sample of coal from the upper bed (p. 42 ) shows it to be of bituminous rank. There seems to be only a few acres at this locality underlain by the coal beds, which are here exposed in a small faulted area, along the eastern extension of the Coal Creek syncline. The deposits were examined by the Navy in 1921, as previously described.

\section{T. 20 N., R. 7 E.}

$7\left(N^{1 / 4 N W 1 / 4}\right.$ sec. 3). In the area between the Coal Creek district and Anthracite Ridge no indications of coal have been found or reported. The 
6

South bank of

Tunnel B
Chickaloo

Chickaloon

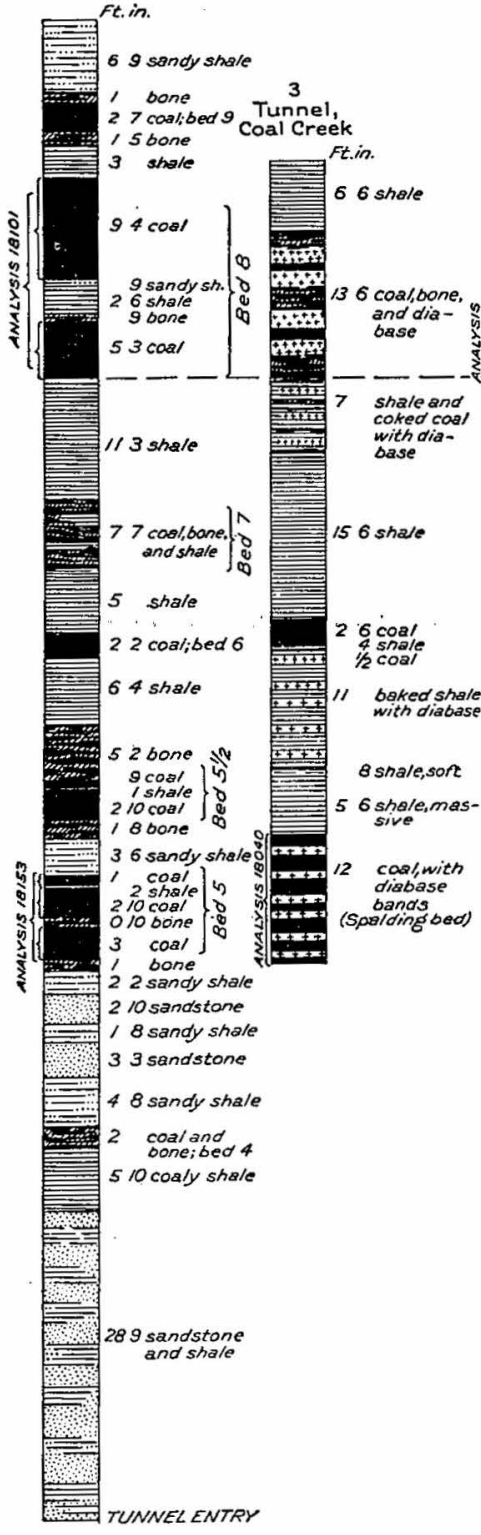

Ft.in.
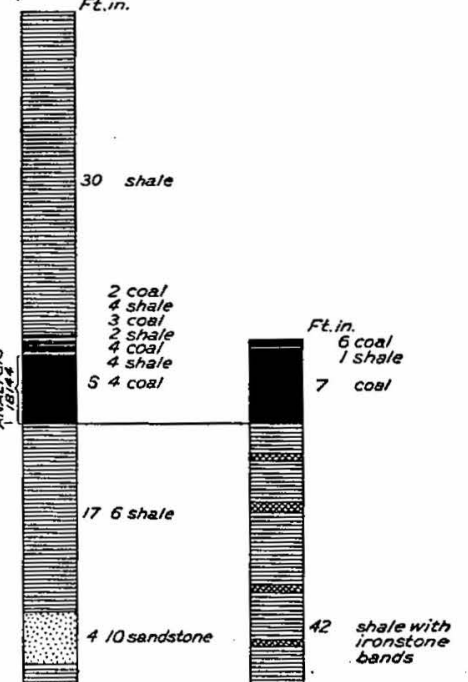

26 concealed

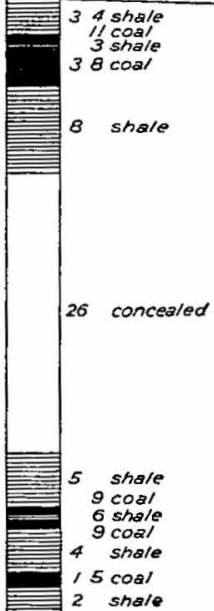

FrguRe 2.-Sections of coal-bearing beds in the Chickaloon and Coal Creek districts. 
northwesternmost showing in the Anthracite Ridge district is near the west end of the ridge, a quarter of a mile north of its crest. Coal blossom (small, loose fragments of coal) has been found there, but no good outcrop of coal. Black shale of the Chickaloon formation is well exposed in the ravines, dipping $60^{\circ}$ S. $20^{\circ} \mathrm{W}$.

$8\left(N W 1 / 4 W^{1} / 4\right.$ sec. 3$)$. On the crest of a southern spur from Anthracite Ridge a pit was dug in 1931 on coal blossom and exposed 2 feet of crushed coal, dipping $70^{\circ}$ N. $25^{\circ}$ E. and underlain by four other coals, 6, 9, 10, and 10 inches thick, separated from one another by a few inches of shale. The analysis of a composite sample from five beds (p. 42) shows the coal to be of semibituminous rank, with unusually low ash content. The steepness of the dip and crushed condition of the coal suggest that the locality has been faulted or landslipped.

$9\left(\mathrm{SE}^{1 / 4} \mathrm{SW}^{1} / 1 / \mathrm{sec}\right.$. 3$)$. On lower slopes a quarter of a mile southeast of locality 8 , a pit exposed 2 feet of crushed coal dipping $70^{\circ}$ N. $20^{\circ}$ E., which may be a portion of the beds that were uncovered at the higher locality.

$10(\mathrm{SE} 1 / 4 \mathrm{SE} 1 / 4$ sec. 3$)$. On the upper slope of the ridge, three quarters of a mile east of locality 9 , about 2 feet of rusty, bony coal is exposed, in a 50-foot band of black shale dipping $60^{\circ} \mathrm{S}$., which lies between thick bands of sandstone. The coal zone seems from the structure to be possibly about the same as that of the exposures farther west.

$11\left(\mathrm{SW} \frac{1}{4} \mathrm{NE} 1 / 4\right.$ sec. 11). In the ravine of the west branch of Meadow Creek 3 coal beds 13, 12, and 8 inches thick are exposed. They are rather widely separated by shale and sandstone beds, as given in the section on plate 9 , the lowest bed being nearly 150 feet below the highest. The series dips about $45^{\circ}$ S. $30^{\circ} \mathrm{W}$.

$12\left(\mathrm{SW}^{1 / 4} \mathrm{NE} 1 / 4\right.$ sec. 11). In the ravine of the middle branch of Meadow Creek there is exposed about 1 foot of bony coal in black shale dipping $30^{\circ}-80^{\circ} \mathrm{S}$. The shale is intruded by two sills, each 1 foot thick. The strike of the beds indicates that the coal is the same as that of locality 11. It may be a western extension of thicker beds which are exposed farther east. The analysis of a sample of the coal (p. 42) shows it to be a semianthracite, but rather high in ash content.

$13(\mathrm{NW} 1 / 4 \mathrm{SE} 1 / 4$ sec. 11). In September 1931 and again in April 1932 considerable trenching and pitting was done on coal indications near the base of a small ridge at the foot of the main slope of Anthracite Ridge. On the western showings 2 feet of crushed coal and coaly shale was uncovered, dipping $70^{\circ} \mathrm{S}$; ; but eastward in a distance of less than 200 yards the coal either pinched out or graded into coaly shale. The analysis (p. 42) shows the coal to be of bituminous rank, with moderate ash content.

$14\left(\mathrm{SW}^{1 / 4} \mathrm{NW}^{1 / 4} \mathrm{sec}\right.$. 12$)$. On the ridge between Meadow and Chikootna Creeks there is coal blossom, and a pit exposed two beds of coal 3 feet and 4 feet 9 inches thick, separated by 15 inches of shale and coaly shale, dipping $60^{\circ} \mathrm{S} .25^{\circ} \mathrm{E}$. Analysis of a composite sample from the two beds (p. 42) shows the coal to be of semianthracite rank, but with rather high ash content.

$15(\mathrm{SW} 1 / 4 \mathrm{NW} 1 / 4$ sec. 12). On the east side of the east branch of Chickootna Creek a pit uncovered coal with shale partings, $5 \frac{1}{2}$ feet in total thickness and dipping $40^{\circ} \mathrm{S}$. The coal seems partly coked and is overlain by 4 feet of baked shale. Although no intrusive rock was noticed immediately above this, such rock is probably present. There is a 10 -foot sill 200 feet to the north, and about 400 feet farther north there is a thick band of diabase from which the thinner sills may be offshoots.

$16\left(\mathrm{NE}^{1 / 4} \mathrm{NW} 1 / 4\right.$ sec. 12$)$. On the divide between Chikootna and Purinton Creeks, a few yards south of a thick band of diabase, there is coal blossom. 
A pit exposed 6 feet 2 inches of coal, divided by three partings of shale and bone and dipping $60^{\circ} \mathrm{S}$. The coal is hard and lustrous and is apparently of semianthracite rank.

17, $18(\mathrm{NE} 1 / 4 \mathrm{NW} 1 / 4$ sec. 12$) ; 19$ (SE1/4NW1/4 sec. 12). On the west side of the ravine of Purinton Creek trenching was done in 1981 on coal outerops at three places. At the northern exposure (locality 17), about 4 feet of coal was uncovered, dipping $45^{\circ} \mathrm{S}$. This is apparently semianthracite and somewhat altered by proximity to a sill 2 feet thick. At the central exposure (locality 18) there are four beds of coal 36,15, 15, and 14 inches thick.

The upper two beds are separated by a 6-inch sill; the others by 3-inch partings of shale. The coals seem to be semianthracite, and the beds dip $40^{\circ} \mathrm{s}$. $20^{\circ} \mathrm{W}$. At the southern exposure (locality 19) about 16 feet of coal was uncovered, between two thin sills of diabase. An analysis of coal from the lowest bed (p. 42) shows it to be semianthracite. The character of the beds in this vicinity is shown on plate 10 .

The coals of localities 16-19 seem from the strike and dip of the beds to be in the same coal-bearing zone. The detailed section at each place is shown on plate 8 .

$20(\mathrm{SE} / 4 \mathrm{NW} 1 / 4$ sec. 12). On the hillside south of west from localities 17-19 a large pit was excavated on coal blossom, and clean coal was found, 24 feet in total thickness. The beds there dip $35^{\circ} \mathrm{SW}$. The coal is divided into 4 benches by shale partings 3 or 4 inches thick. Analyses (pp. 42-43) of a sample from the upper bench of 10 feet of coal and of a combined sample from the second and third benches of 3 feet and 4 feet of coal, respectively, show them both to be semianthracite. A sample from the lowest bench of 7 feet of coal shows it to be of lower rank, the greater percentage of volatile matter making it a semibituminous coal. It is of interest to find the lowest third of this 24-foot coal deposit to be less devolatilized than the upper portion.

$21\left(\mathrm{SE}_{1} / 4 \mathrm{NW} 1 / 4 \mathrm{sec}\right.$. 12). About 100 yards east of the large pit another was dug on coal blossom, and a thickness of 6 feet 4 inches of coal was exposed, dipping $30^{\circ} \mathrm{S}$. The coal is there split into three members of 32,10 , and 34 inches, the upper and middle members separated by a 3-inch shale parting and the middle and lower by a 5-inch sill of diabase. Analyses of a combined sample of coal from the upper two members and one from the lowest member (p. 43) show them to be semianthracite. The upper members have rather high ash content. The lowest member ranks almost as an anthracite, possibly because of the proximity of the thin sill; and a separate analysis of coal from the 10-inch member might have shown it also to be nearly an anthracite. Although the coal is much thinner than at the large pit, it seems to be a portion of the same bed or beds.

$22(\mathrm{SE} 1 / 4 \mathrm{NW} 1 / 4$ sec. 12). On the west side of the ravine of Purinton Creek 100 yards east of locality 21 the same beds were prospected by trenching and found to dip $25^{\circ} \mathrm{S} .10^{\circ} \mathrm{W}$. The coal is there divided into upper and lower principal members, 36 and 34 inches thick, with 2 intermediate bands of broken coal 20 and 10 inches thick. The uppermost coal is immediately underlain by a sill of diabase 8 feet thick; the other members are separated by a few inches of shale or bone. Analyses of coal from the upper and lower members (p. 43) show them both to be semianthracite, similar to the coal of the same beds at localities 20 and 21 .

$23(\mathrm{SE} 1 / 4 \mathrm{NW} / 4 \mathrm{sec}$. 12). On the west bank of the ravine of Purinton Creek 200 to 300 feet north of a small mass of diabase a bed of coal is exposed which has an apparent thickness of 35 to 40 feet. It is the most prominent exposure of coal in the district and has been the cause of much specula- 


\section{GEOLOGY OF ANTHRACITE RIDGE COAL DISTRICT, ALASKA}

tion as to the size of the deposit. This bed seems to be within the south limb of a syncline and dips about $20^{\circ} \mathrm{N} .20^{\circ} \mathrm{E}$.; but the coal seems to be cut off on the north and south and also on the east by minor faults. On the east bank of the ravine, where the coal should be if unfaulted, there are thinbedded sandstones overlying shales, which probably in turn overlie the coal. Coal blossom on a small ridge 100 yards west of the bed and the appearance of the hillside just above it suggest that this so-called "big bed" of coal is in part landslipped. Although the coal is hard, it is considerably fractured. The section of the ledge as measured in 1931 by $R$. W. Richards is given on plate 8. Four analyses, covering the entire thickness of coal (p. 43), show the coal to be semianthracite, with rather high ash content but also fairly high heating value.

24 (NE1/4 SW1/4 sec. 12). About 500 yards southwest of the "big bed" there is coal blossom for several hundred feet along the brow of a bluff, and excavations made in 1931 and 1932 uncovered 2 to 6 feet of broken coal underneath sandstone dipping $10^{\circ} \mathrm{N}$. $30^{\circ}$ E. The bluff is nearly 400 feet high and is formed by a thick sill of diabase, the coal apparently being about 50 feet sbove the top of the sill. The analysis of coal from the west end of the bluff (p. 43) shows the highest fixed carbon and highest fuel ratio of all the coals sampled from this district. A burning test of 80 pounds of this coal was made in June 1932 by Maurice L. Sharp, chemist of the United States Bureau of Mines at Anchorage, in the heating furnace of the laboratory. He summarized the results as follows:

"The coal proved to be suitable for fuel when fired under the necessary conditions. The ash did not clinker or fuse but retained its original shape until entirely consumed. Much of the coal appoiared stained with rust, and some bone was noted. The coal crackles when first introduced to the fire bed."

$25(\mathrm{NE} 1 / 4 \mathrm{SW} 1 / 4$ sec. 12$) ; 26(\mathrm{NW} 1 / 4 \mathrm{SE} 1 / 4$ sec. 12$)$. From the coal exposures of locality 24 the beds flatten northward to a shallow syncline and then are turned up to steep south dip, where ledges in the ravines at localities 25 and 26 expose 10 to 15 feet of black shale and coaly shale. Prospect trenches across these beds uncovered only thin lenses of coal in the coaly shale. The section at locality 25 is given on plate 8 .

$27-31\left(N{ }^{1} / 4 \mathrm{SE}_{1 / 4} \mathrm{sec}\right.$. 12). The slopes of the ridge that separates the east branch of Purinton Creek from Shuna Creek do not show good exposures of bedded rocks in place, in the zone between the areas of igneous rock. (See pl. 2.) This area is apparently faulted and much broken. The coal zone has constituted a part of this broken area, and hence coal blossom shows at a number of places. Excavations were made in 1931 at localities 27-31. In each locality 2 to 6 feet of crushed coal was uncovered, but no solid bed was found. The observed dips of about $30^{\circ} \mathrm{S}$. may conform approximately to the attitude of the broken blocks of this faulted zone.

32 (NE1/4 SE1/4 sec. 12). About 2 feet of broken coal is exposed on the west side of the gorge of Tukmakna Creek, half a mile east of the last-described outcrops. On the steep slope the surface rocks are slumped, but the dip of the coal probably conforms to that of the enclosing shales and the underlying sill, which is $30^{\circ} \mathrm{N} .20^{\circ} \mathrm{E}$.

\section{T. 20 N., R. 8 E.}

$33\left(N^{1 / 4} \mathrm{SW}_{1 / 4}\right.$ sec. 7$)$. On the east side of the gorge of locality 32 a trench was dug in 1931, at locality 33, exposing 4 feet of coal and coaly shale dipping $30^{\circ} \mathrm{N} .20^{\circ}$ E. The two exposures are apparently of the same 
coal bed, and their position about 50 feet above the thick sill suggests that they belong to the same coal horizon as the bed of locality 24 .

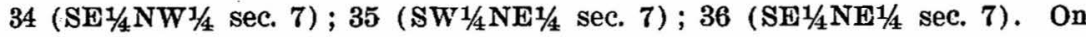
the upper slope of Anthracite Ridge about 200 feet north of the whitened band in the sandstone and shale but stratigraphically 130 feet below it, coal blossom was noticed at three places. At locality 34 about 2 feet of crushed coal dipping $20^{\circ} \mathrm{N}$. (overturned) was uncovered by digging. At locality 35 there was 2 feet of coaly shale, dipping $80^{\circ} \mathrm{N}$., also overturned. At the eastern exposure (locality 36 ) there was 2 feet of coaly shale, overturned to a dip of $20^{\circ} \mathrm{N}$. The details of the folding on these upper slopes are well exhibited by the band of whitened beds, as shown on plate 6 and in cross section $\mathbf{C}-\mathbf{C}^{\prime}$, of plate 4. No evidence of the coal horizon was found farther south below the whitened band on the lower slopes.

37 (NW $1 / 4$ NE $1 / 4$ sec. 18). Trenching was done in 1931 on showings of coaly shale on the west side of Kutzkatna Creek, in a place where the Chickaloon beds are intruded and locally altered by several sills 2 to 10 feet thick. A bed of 7 feet of coaly shale, dipping $50^{\circ} \mathrm{S}$., was uncovered, but at this spot it did not show any clean coal.

$38(N W 1 / 4 N W / 4$ sec. 17$)$. The coaly shale of locality 37 may be near the eastern margin of an original small area of coal deposition, for thence eastward the next blossom observed was three-quarters of a mile away, at locality 38. Here, as at locality 37 , coaly shale was uncovered near a group of thin sills. About 2 feet of the coaly material was measured, dipping $60^{\circ} \mathrm{SW}$. The two localities might be correlated as being of approximately the same horizon; but the structure in the area between them is so complex that such correlation cannot be definitely made on the basis of data at hand.

$39\left(\mathrm{NE}_{1 / 4} \mathrm{SW}^{1} / 4\right.$ sec. 9$)$. On the crest of a small spur on the upper slope of Anthracite Ridge 6 inches of coal dipping $10^{\circ} \mathrm{NW}$. was seen. This lies 100 feet above the whitened band and dips conformably with the other rock of the vicinity. It is probably a small lens in the shales, much higher stratigraphically than the principal coal outcrops.

40 (NE1/4 NE1/4 sec. 17) ; 41 (NW1/4NW1/4 sec. 16) ; 42 (NE1/4NW1/4 sec. 16). On the slopes below locality 39 , in an area drained by the headwaters of Winding and Muddy Creeks and Packsaddle Gulch, there are numerous showings of coal. The westernmost prominent exposure is at locality 40 , in the ravine of upper Winding Creek, where a 5-foot coal bed lies about 50 feet above a sill of diabase 10 feet thick. The beds here dip $10^{\circ} \mathrm{N} .10^{\circ} \mathrm{E}$. An analysis (p. 43) shows the coal to be of bituminous rank, with a rather high percentage of ash. Its fuel ratio of only $\mathbf{1 . 5}$ indicates that the coal has been unaffected by the sill below it. The section exposed here is given on plate 9 . In two other places to the east where the coal bed and the sill cross ravines, at localities 41 and 42, they maintain the same relative positions; but the exposures of beds are not so good and show only 3 feet of coal, dipping about $60^{\circ} \mathrm{N}$.

$43\left(\mathrm{NE}^{1 / 4} \mathrm{NW} 1 / 4\right.$ sec. 16$) ; 44(\mathrm{SE} 1 / 4 \mathrm{SW} 1 / 4$ sec. 9). On the west side of the ravine of Muddy Creek, a quarter of a mile east of locality 42 , there are several thin beds of coal, perhaps 3 feet in total thickness, in a series of $\mathbf{5 0}$ feet of beds dipping $20^{\circ} \mathrm{S} .20^{\circ}$ E. Northward for 100 yards the beds increase in dip, to a minor anticlinal fold on whose north limb the beds dip aljout $80^{\circ}$. About 200 yards north of the crest of this small fold, coal is again exposed at locality 44 in a small, sharp syncline or possibly a minor fault. About 3 feet of coal is exposed, dipping $80^{\circ} \mathrm{NW}$.

$45(\mathrm{SW} 1 / 4 \mathrm{SE} 1 / 4 \mathrm{sec} .9)$. The most prominent exposure of coal on upper Muddy Creek is on the east side of the main ravine, where the beds are closely 


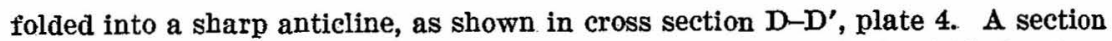
measured across the beds on the north limb, to the axis of the fold, is given on plate 9. The lowest coal bed, containing 6 feet 2 inches of coal divided into two nearly equal members by a shale parting, is doubled into a hairpin fold. The analysis of a sample taken halfway up the side of the ravine, across the lowest bed, excluding the shale parting (p. 43), shows the coal to be of rather low bituminous rank, with the same fuel ratio (1.5) as the coal at locality 40 but with higher ash content.

$46\left(\mathrm{SE}_{1} 1 / \mathrm{SE} 1 / 4\right.$ sec. 9$)$. On the crest of the ridge above locality 45 there are five beds of coal, all considerably crushed. Southward along the ridge they measure $2,2,2,4$, and 10 feet in thickness. The group is probably equivalent to the coal beds of the section measured halfway down the slope. They all dip $60^{\circ} \mathrm{N}$. $30^{\circ} \mathrm{W}$. and are apparently in an up-faulted portion of the coal-bearing series, for the corresponding portion of the south limb of the fold does not seem to be present along the crest of the ridge.

47 (SE $1 / 4 \mathrm{SE}_{1} 1 / 4$ sec. 9 ). On the east slope of the ridge below locality 46 a 2 -foot bed of coal at locality 47 dips $50^{\circ} \mathrm{S}$. $10^{\circ} \mathrm{E}$. and is probably of the same zone as the beds on the crest. Several landslips in this vicinity contain detached portions of a sill and give evidence of the character of the faulting.

48 (NW $1 / 4$ NE1/4 sec. 16). On the east bank of upper Muddy Creek four coal beds are exposed, $48,6,9$, and 6 inches thick. They seem to dip $50^{\circ} \mathrm{N}$. $30^{\circ} \mathrm{W}$., but the slopes above are landslipped, and the block containing the coal may have come down from a locality near the crest of the ridge, 300 or 400 yards to the east. Whether they are in place or have been faulted or landslipped to their present position, the coals are very probably portions of the beds exposed farther up the ravine.

$49\left(\mathrm{NE} 1 / 4 \mathrm{NE}^{1} / 4\right.$ sec. 16$)$. On the crest of the ridge 200 feet north of a sharp anticlinal axis a 5 -foot bed of coal is exposed, dipping $70^{\circ}$ N. $20^{\circ}$ W. Stratigraphically it seems to be of the same zone as the coal beds farther north.

$50\left(\mathrm{NW}^{1 / 4} \mathrm{NW}^{1} / 4 \mathrm{sec}\right.$. 15). On the west side of upper Packsaddle Gulch there are beds of shale and ironstone, with several thin lenses of coal, and two beds, each about 9 inches thick, of coal which has been somewhat altered by an adjacent sill 2 feet thick. The materials are in a landslipped mass which has come eastward down from a locality near the crest of the ridge that separates Packsaddle Gulch from Muddy Creek, in a similar way to that in which the coals at locality 48 probably reached their present position.

51-53 (SW1/4NW1/4 sec. 15) ; 54 (NW1/4 SW1/4 sec. 15); 55 (SE1/4 SW $1 / 4$ sec. 15). Along the southern portion of the ridge that separates Muddy Greek from Packsaddle Gulch coal and coal blossom show at several places. At localities 51,52 , and 53 there are two beds of rather bony and shaly coal, 4 feet and 2 feet thick, separated by 20 feet of shale. The series dips $50^{\circ} \mathrm{S}$., and the three exposures are separated by faults of 40 -foot throw, uplifting the beds to the south and causing their repetition. About 30 yards south of locality 53 a vertical dike of diabase 10 feet thick is exposed, and 100 yards farther south along the ridge the two coal beds are again exposed, at locality 54, with dip flattened to $30^{\circ}$ and turned in direction to southwest. Thence southward along the east brow of the ridge the coal horizon is marked by coaly shale to the point of the ridge at locality 55, where the upper bed has thickened to 5 feet of bony coal dipping $30^{\circ} \mathrm{SW}$. The lower coal bed is not visible at this place.

$56\left(N^{1} / 4 N^{1 / 4}\right.$ sec. 22$)$. On the southernmost point of the ridge the two coal beds have thickened and turned in dip to $20^{\circ} \mathrm{NW}$. and are exposed in a section as given on plate 9. Analysis of a sample of coal from the upper bed (p. 43) 


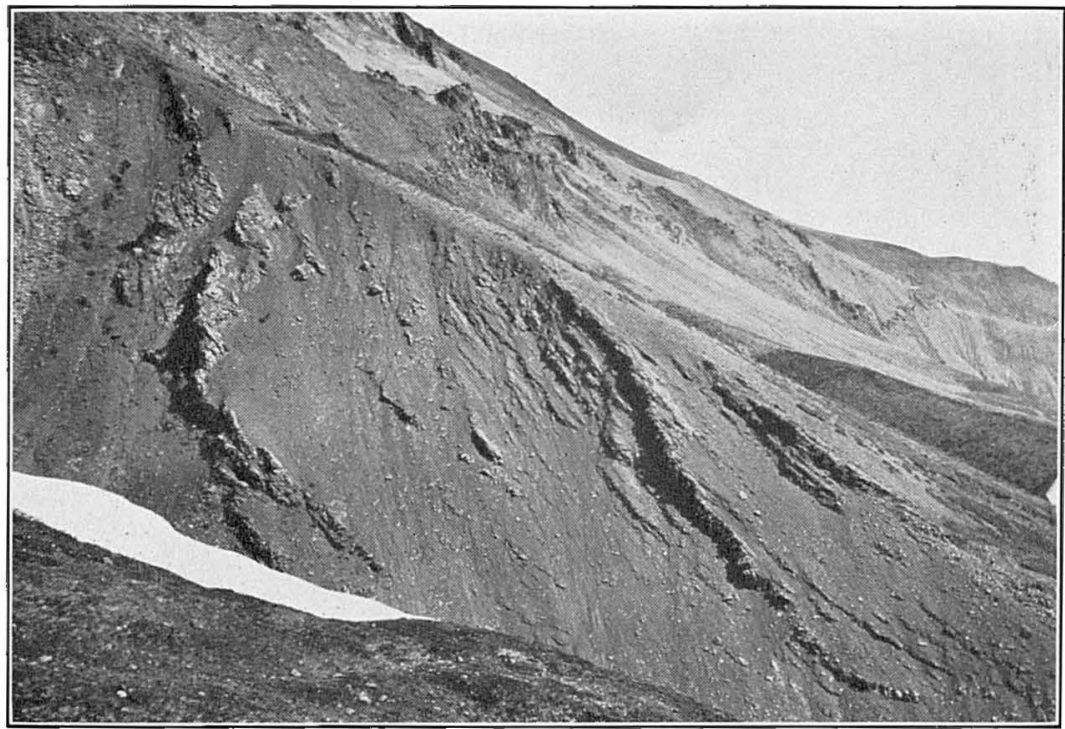

A. COAL BEDS AND DIABASE SILLS ON WEST BRANCH OF UPPER PURINTON CREEK.

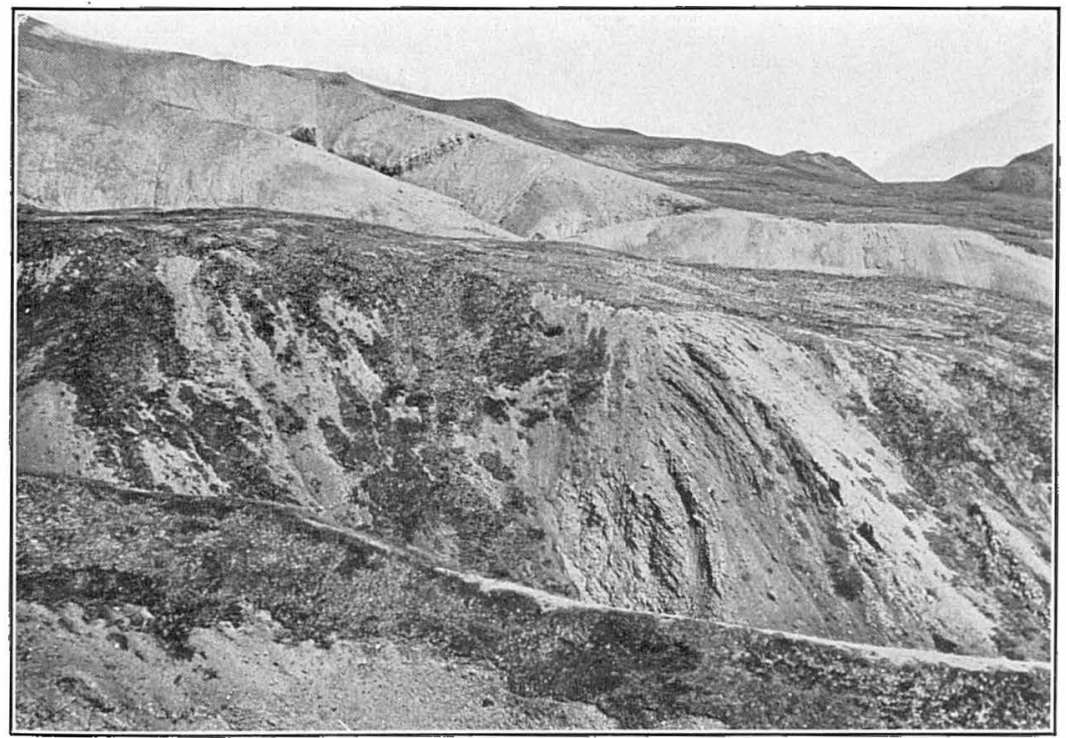

B. FOLDED SHALE AND SANDSTONE ON EAST BRANCH OF UPPER PURINTON CREEK. 


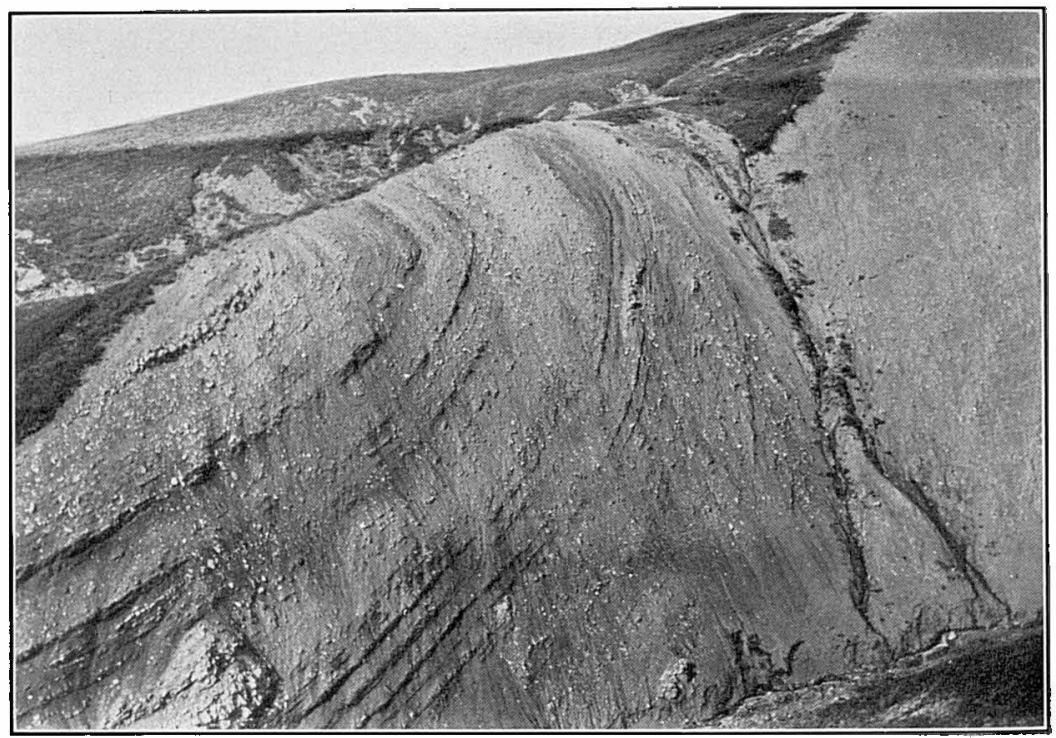

A. THIN COAL BEDS ON MUDDY CREEK,

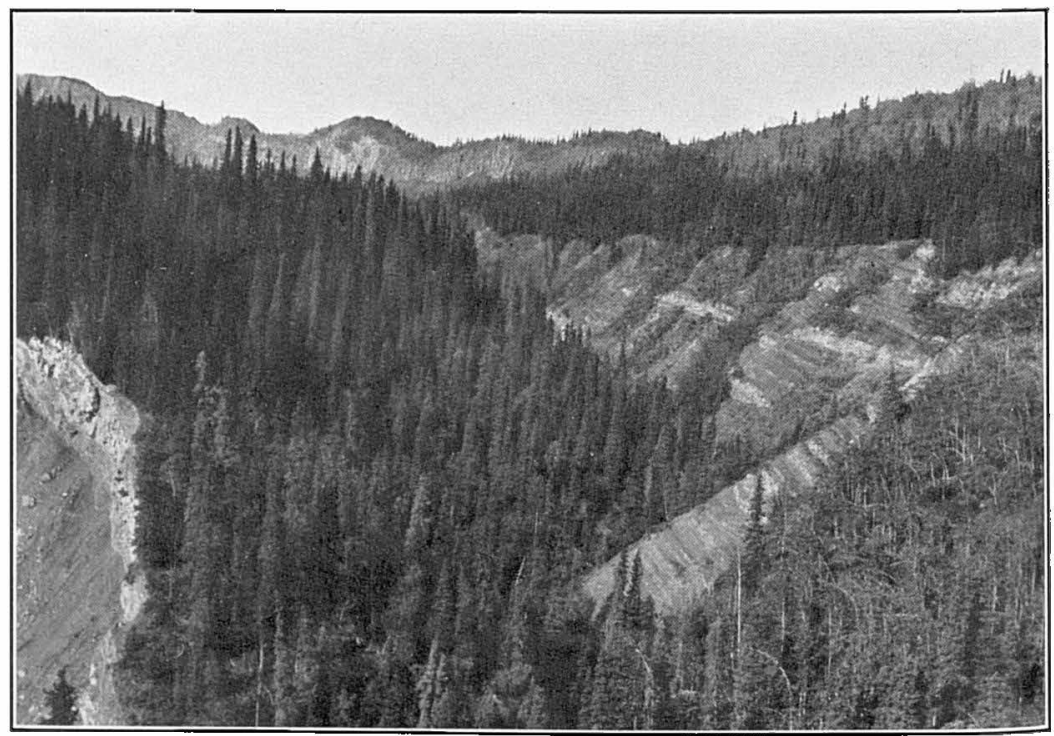

B. COAL-BEARING BEDS ON LOWER PURINTON CREEK. 
shows it to be of bituminous rank, with a moderate ash content and a fuel ratio of 1.9 .

$57(\mathrm{NE} 1 / 4 \mathrm{NE} 1 / 4$ sec. 21$)$. In a ravine 250 yards west of locality 56 the zone of the two coal beds is indicated by black shale, but the coals have either pinched out or graded laterally into shale. The horizon of the upper coal bed is represented by 1 foot of coaly shale, dipping $10^{\circ} \mathrm{NW}$., but evidence of the lower coal bed was not found at this place.

$58(\mathrm{SE} 1 / 4 \mathrm{NW} 1 / 4$ sec. 16$) ; 59,60$ (SW1/4 NE1/4 sec. 16) ; 61 (NW1/4 SE1/4 sec. 16). At several places in the ravine of Muddy Creek in sec. 16 coal is exposed. One of the most prominent places is at locality 58 (pl. 11, A), where eight thin beds, containing about 3 feet of coal, are upturned against a fault. About 50 yards downstream, on the opposite (east) side of the ravine, two or three thin coal beds are exposed at locality 59. The apparent dip is about $40^{\circ} \mathrm{SW}$., approximately conformable with the beds on the west side of the ravine; but they seem to be landslipped. About 300 yards farther downstream and again 200 yards still farther south, at localities 60 and 61 , there are showings of about 2 feet of coal, but in each place the beds are probably landslipped.

$62\left(\mathrm{NE}_{1} / \mathrm{SW} 1 / 4\right.$ sec. 16$)$. On the west side of Muddy Creek coal beds which are evidently of the same horizon as those at localities 58 to 61 are exposed in a small side ravine. Several thin beds were seen, with a total of about 2 feet of coal; they dip $30^{\circ} \mathrm{SW}$, conformably with the other beds of the Chickaloon formation in this place.

$63\left(\mathrm{NE}_{1}^{1 / 4} \mathrm{SW} 1 / 4 \mathrm{sec}\right.$. 16). The southernmost prominent exposure of coal on Muddy Creek is near the level of the stream at the base of a bluff capped by a thick sill of diabase. The sill and underlying beds dip $30^{\circ} \mathrm{SW}$., and the section measured here is given on plate 9. A sample was taken from the principal coal bed, near the base of the section. The analysis (p. 43) shows this to be a bituminous coal of fair quality, with moderate ash content.

$64\left(\mathrm{NE}^{1 / 4} \mathrm{NW}^{1 / 4}\right.$ sec. 21$)$. On the bank of Muddy Creek at locality 64 there is a remnant of black shale overlying a thick sill, in the axis of a shallow syncline. In the shale there is 1 foot of coaly shale dipping $20^{\circ} \mathrm{W}$. This may be a local lens, higher in the formation than the principal coal beds of the Muddy Creek area, for these all seem to underlie the thick sills.

65. ( $\mathrm{SE}^{1} / 4 \mathrm{NW}^{1 / 4} \mathrm{sec}$. 22). In the middle part of Packsaddle Gulch evidence of coal was noticed only at locality 65 , where there is 1 foot of coaly shale, dipping $20^{\circ} \mathrm{NW}$. This dip is conformable with that of the coal beds at locality 56, half a mile to the northwest, and the coaly shale is probably a minor bed several hundred feet lower in the formation than the coal beds. This thin coaly shale is at approximately the eastern margin of the coal basin.

$66\left(\mathrm{NE}_{1 / 4} \mathrm{SE} 1 / 4\right.$ sec. 21$)$. On the lower slopes east of Muddy Creek a pit dug on coal blossom uncovered 2 feet of coal, dipping $30^{\circ} \mathrm{S} .10^{\circ}$ E. The structure of the shales exposed to the west, in the banks of Muddy Creek, indicates that the coal showing is on the south flank of a small anticlinal fold.

67 (SW1/4 NE $1 / 4$ sec. 19$) ; 68,69$ (NE $1 / 4 \mathrm{SW}^{1 / 4}$ sec. 19). Along the middle portion of Cascade Creek the structure is well shown by beds which gradually flatten southward to a syncline. At three places beds of coaly shale about 1 foot thick were seen dipping $\mathrm{S}$. $30^{\circ} \mathrm{E}$., at angles of $30^{\circ}, 10^{\circ}$, and $5^{\circ}$. They are evidently at three separate horizons in the formation.

\section{T. 20 N., R. 7 E.}

$70(\mathrm{SW} 1 / 4 \mathrm{NW} 1 / 4$ sec. 23 ). In the southwest part of the district thin beds of coal are exposed at several places along lower Purinton Creek. Where the creek passes between prominent ridges of diabase, black shale is exposed on 
its south bank, and excavations were there made in 1931 on coal showings. About 3 feet of crushed coal and coaly shale was uncovered, dipping $70^{\circ} \mathrm{N}$. This material is overlain by black shale and underlain by 2 feet of gray shale containing leaf impressions, beneath which is thin-bedded sandstone. The analysis of a sample of the coal (p. 44) shows it to be of bituminous rank with moderate ash content.

$71,72(\mathrm{NW} 1 / 4 \mathrm{SW} 1 / 4$ sec. 23$) ; 73\left(\mathrm{NE}_{1 / 4} \mathrm{SW} 1 / 4\right.$ sec. 23$) ; 74,75 \quad\left(\mathrm{SE}^{1 / 4} \mathrm{SW} 1 / 4\right.$ sec. 23). On the east side of lower Purinton Creek (see pl. 11, B) two thin beds of coal and coaly shale can be traced fairly continuously for some distance. At locality 71, near the top of the bluff, there is 1 foot of coaly shale, dipping $20^{\circ} \mathrm{N} .20^{\circ} \mathrm{E}$. Downstream this becomes more coaly, and at locality 72 it is 14 inches thick. The analysis of a sample from this place (p. 44) shows it to be a semibituminous coal with low ash content. At the outcrop it is very friable. In the lower part of the gorge, at locality 73 , there is a 6 -inch bed of coal, which may be traced for 200 yards, to locality 74 . A quarter of a mile farther downstream, at locality 75, the beds are well exposed where the surface soil. has been removed by a large landslip. In the lower part of the bluff there are two beds, each about 18 inches thick, of friable, shaly coal.

$76\left(\mathrm{NE}^{1 / 4} \mathrm{NW} 1 / 4\right.$ sec. 26$)$. A great landslip scar at locality 76 exposes the beds from top to bottom of the gorge. The section measured here in 1931 by $R$. W. Richards is given on plate 9 . It shows six coal beds, $16 \frac{1}{2}$ feet in total thickness. The rocks steepen in dip from about $40^{\circ}$ at the top to $80^{\circ}$ at the bottom of the gorge, whereas at another landslide exposure 100 yards to the northwest, the beds steepen from $40^{\circ}$ at the base to $60^{\circ}$ at the top of the section. These irregular dips are probably indicative of faulting, along the northern portion of a cross fault which brings to the surface the Upper Cretaceous beds of the prominent ridge west of Purinton Creek.

$77\left(\mathrm{SW}_{1 / 4} \mathrm{NE} 1 / 4\right.$ sec. 26$) ; 78$ (NW1/4 SE1/4 sec. 26). Farther down Purinton Creek coal is again exposed in a landslide scar at locality $\mathbf{7 7}$, where the beds dip $50^{\circ} \mathrm{s} .70^{\circ} \mathrm{E}$. Two thin beds of coal are exposed near the top and two beds of coaly shale in the lower part of the section, measured as shown on plate 9. The southernmost exposure of coal noted along the creek was at locality 78, where 1 foot of coaly shale dips $10^{\circ} \mathrm{NE}$.

The coals of localities 71 to 78 seem to form a group of thin beds in a series of about 400 feet of shale and lenticular sandstone.

79 (NE $1 / 4 \mathrm{NE}^{1} / 4$ sec. 26 ). On a ridge east of Purinton Creek coal blossom was noticed in 1931, about 75 feet below a sill of diabase that forms the crest of the ridge. On excavation 18 inches of coal was exposed, dipping $60^{\circ} \mathrm{E}$. The analysis (p. 44) shows it to be of semibituminous rank with very low ash content. Some portions of the coal show steely luster, as if partly coked, presumably by adjacent igneous rock. On excavating along the coal it was found to be a lens, pinching to 3 or 4 inches within 15 feet each way from the thickest showing. It seems to be stratigraphically several hundred feet above the nearby coals of Purinton Creek.

$80\left(\mathrm{NW}_{1} / 4 \mathrm{SE}_{1} 1 / 4 \mathrm{sec}\right.$. 25$)$. On the east side of Conglomerate Creek 2 feet of conly shale is exposed, dipping $45^{\circ} \mathrm{S} .80^{\circ}$ E., in a locality where the rocks have been considerably disturbed by faulting. The coaly material is in shale 50 feet or more thick, between thick beds of conglomeratic sandstone.

T. 20 N., R. 8 E.

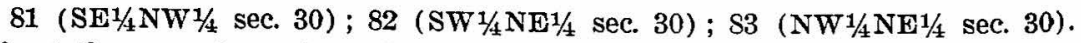
About three-quarters of a mile northeast of locality 80 similar coaly shale is exposed in the ravine of Cascade Creek. At localities 81, 82, and 83 there is 
6,12 , and 6 inches of the coaly material, flattening northward in dip from $20^{\circ}$ to $10^{\circ}$. This flattening continues to the axis of a syncline nearly half a mile north of locality 83. The structure of the beds to the north indicates that the three coaly zones correspond approximately with those of localities 67,68 , and 69 , on the north limb of the syncline.

$84\left(\mathrm{SE}^{1 / 4} \mathrm{NW}^{1 / 1} \mathrm{sec}\right.$ s3); $85\left(\mathrm{SW}^{1 / 4} \mathrm{NE}^{1 / 4}\right.$ sec. 33$)$. Cliffs along the north side of the Matanuska River show good sections of the Chickaloon beds, and at several places beds of coal and coaly shale are exposed. At locality 84 there is 5 feet of coaly shale near the top of the bluff, in black shale dipping $40^{\circ} \mathrm{N}$. $30^{\circ} \mathrm{W}$., beneath thick-bedded sandstone. At locality 85 , in the bluff just west of the mouth of Muddy Creek, there is 1 foot of coaly shale with the same dip as that farther west.

$86\left(\mathrm{NE}^{1 / 4} \mathrm{NE} 1 / 4\right.$ sec. 33$) ; 87$ ( $\mathrm{SE}^{1 / 4} \mathrm{SW} 1 / 4$ sec. 27 ). In the bluff 200 yards east of Muddy Creek 1 foot of coal is exposed at locality 86, in a series of shale and sandy shale dipping $30^{\circ} \mathrm{NW}$. The coal can be traced fairly continuously eastward along the bluff, and at locality 87 it is 16 inches thick. The coal is friable and appears to be of bituminous rank.

$88\left(\mathrm{NW}^{1 / 4} \mathrm{SW}^{1 / 4}\right.$ sec. 27$)$. On Muddy Creek half a mile north of the river 1 foot of coaly shale is exposed in beds that dip $30^{\circ} \mathrm{NW}$. Although no coal was observed in the banks of this portion of Muddy Creek, the material forms a carbonaceous zone in which there may be thin coal beds.

$89\left(\mathrm{SW}^{1} / 4 \mathrm{NE}^{1} / 4\right.$ sec. 27$)$. The eastern limit of the coal-bearing beds on the north side of the Matanuska River is at locality 89, where the Chickaloon shale and sandstone are sharply upturned against a fault that has brought to the surface the Upper Cretaceous marine sandstone and shale. The water of Packsaddle Gulch cascades down the steep slope to the river, less than 100 yards west of the contact of the two formations. The coal-bearing portion of the section there exposed is about as shown on plate 9 , and includes two thin coal beds. Analyses of samples from these beds (p. 44), 18 and 15 inches thick where they were sampled, show them both to be of semibituminous rank. The surface coal is very friable, but where unweathered it may be more solid.

$$
\text { T. } 19 \text { N., R. } 8 \text { E. }
$$

$90\left(\mathrm{NE}_{1} / \mathrm{SE} 1 / 4\right.$ sec. 5). On the south side of the Matanuska River in the vicinity of O'Brien Creek there are several showings of coal beds. At locality 90 , about 500 yards west of the creek, there are two beds, 24 and 15 inches thick, with six other beds only a few inches thick, as given in the section on plate 9. The beds dip $40^{\circ} \mathrm{S} .12^{\circ} \mathrm{E}$.

91, $92\left(\mathrm{NW}^{1 / 4} \mathrm{SW}^{1 / 4}\right.$ sec. 4$) ; 93$ (SW $1 / 4 \mathrm{SW}^{1 / 4} / 4$ sec. 4$)$. In the ravine of O'Brien Creek, a quarter to half a mile above its mouth, coal is exposed in three places. At the lowest place (locality 91) there is a bed of coal 4 feet thick, underlain by six other beds 15 to 30 inches thick and several thinner ones, as given in the section on plate 9. These beds stand nearly vertical, the measured dip being $87^{\circ} \mathrm{S}$. $20^{\circ} \mathrm{W}$. The other localities, 92 and 93 , are about 100 yards farther upstream. They expose coaly beds 25 feet thick, containing numerous shale partings. These beds apparently overlie the coal of locality 91 and are of a zone that has been folded into an overturned syncline, whose limbs form the exposures.

94, $95\left(\mathrm{NW}^{1 / 4} \mathrm{SE} 1 / 4\right.$ sec. 4). The coal beds of O'Brien Creek are again exposed in two places in a gulch 600 yards farther east. At the lower place (locality 94) there is nearly 4 feet of coal, underlain by 2 feet of shaly coal and shale. At the upper place (locality 95) there is only 8 inches of coal, underlain by 2 feet of shale containing some coal. In both places the rocks 
dip gently northeast. The rocks between O'Brien Creek and this gulch are evidently faulted or sharply folded. The relation of the several coal beds is not clear, but apparently they represent two coaly zones.

\section{CLASSIFICATION}

Coals are not susceptible of rigid classification, for the various kinds differ in physical as well as chemical properties. Coals that are chemically similar may differ so much in their physical characteristics that they are not suitable for the same uses. In general, the percentage of fixed carbon is a fair indication of the quality of the coal; but the fuel ratio (percentage of fixed carbon divided by the percentage of volatile matter) is more satisfactory for the comparison of different coals. Campbell ${ }^{25}$ says that the term "rank" is

used to designate those differences in coal that are due to the progressive change from lignite to anthracite, a change marked by the loss of moisture, of oxygen, and of volatile matter. This change is generally accompanied by an increase of fixed carbon, of sulphur, and probably of ash. When, however, one coal is distinguished from another by the amount of ash or sulphur it contains, this difference is said to be one of grade. Thus "a high-grade coal" means merely one that is relatively pure, whereas "a high-rank coal" means one that is high in the scale of coals, or, in other words, one that has suffered devolatilization and that now contains a smaller percentage of volatile matter, oxygen, and moisture than it contained before the change occurred.

Anthracite is a hard, bright black coal which breaks with a conchoidal fracture. It contains about 85 to 95 percent of fixed carbon, with low amounts of volatile matter, the fuel ratio being greater than 10. It ignites slowly, burns with little flame or smoke, and does not soften or swell on burning.

Semianthracite is a hard coal, though not so hard as anthracite. The percentage of fixed carbon is about 80 to 85 , and the fuel ratio is between 10 and 6 or 7 . The lower limit is not very definite, for some hard coals have fuel ratio as low as 6 , whereas some soft coals have fuel ratio as high as 7 . Semianthracite contains more gas and hence kindles more readily and burns more freely than does anthracite.

Semibituminous coal contains about 65 to 80 percent of fixed carbon, with a fuel ratio between 6 or 7 and 3. It ignites easily and burns freely and rapidly, giving an intense heat with little smoke. It is considered the best coal for use under steam boilers, because of its quick and intense heat production.

Bituminous coals are of many varieties, with fixed carbon ranging from about 42 to 65 percent. The fuel ratio has a maximum of about 3 . In some bituminous coals the relatively large content of volatile matter consists in part of gases, oils, and tars, in addition

\footnotetext{
2s Campbell, M. R., The coal fields of the United States, General introduction: U. S. Geol. Survey Prof. Paper 100-A, p. 3, 1917.
} 
to the usual organic matter, and these coals burn with a yellow, smoky flame. Many of the bituminous coals will coke. These are rich in hydrocarbons and are valuable for gas making. When heated they swell and fuse to a spongy mass overlying the fire. The noncoking coals do not melt; they hold their shape and burn freely.

Subbituminous coals are somewhat lower in fixed carbon than bituminous coals, from which they can usually be distinguished by their physical properties. On exposure to air subbituminous coals lose moisture and develop shrinkage cracks, which cause them to slack (break down into powder) when subjected to alternate wetting and drying. Good bituminous coal will not thus break down, although owing to fracturing it may disintegrate into fine pieces. Each small fragment of bituminous coal will remain fresh and unaltered for years, however; whereas a subbituminous coal, on slacking, undergoes chemical as well as physical disintegration.

Lignites are readily distinguished from subbituminous coals, as they are brown and show either distinct woody or uniform claylike texture. The percentage of volatile matter in lignite is usually higher than that of fixed carbon, so that the fuel ratio is less than 1. The lignites contain more moisture than subbituminous coals, the content usually ranging from 20 to 40 percent. This reduces the heating value and usually prevents extensive shipment, both because of the freight charges on the large amount of contained water and the fact that, when much of this is lost on exposure to the air, the lignite slacks and is susceptible to spontaneous combustion.

\section{ANALYSES}

The following table gives analyses of samples of coal from some of the localities indicated on plate 1 and described in the preceding pages. Most of the analyses are presented in four forms. Form A shows the composition of the sample as received at the laboratory, which usually contains more moisture than the commercial coal. Form B shows the composition of a sample after being air-dried until its weight is constant and is the form best adapted for the comparison of different coals. Forms $\mathrm{C}$ ard D, computed respectively as free from moisture and free from moisture and ash, are of use in comparing the heating values of different coals.

The first four analyses, of samples from Chickaloon, Coal Creek and the south side of Matanuska River, were made by the United States Bureau of Mines. ${ }^{26}$ All the other analyses were made in

\footnotetext{
w Fieldner, A. C., Smith, H. I., Paul, J. W., and Sanford, Samuel, Analyses of mine and car samples of coal collected in the fiscal years 1913 to 1916 : U.S. Bur. Mines Bull. 123, pp. 26-28, 1918.
} 
1931 and 1932 by Maurice L. Sharp, chemist of the Bureau of Mines, stationed at Anchorage, on samples collected during the course of the geologic study of the district. The last 10 analyses represent samples scraped from veinlets of coal in pieces of diamond-drill core, and the apparent ash content is unduly high because of the particles of shale unavoidably incorporated with the sample. The softening temperature of the ash was determined on four samples by $\mathbf{H}$. M. Cooper, chief chemist, Bureau of Mines, Pittsburgh, Pa.

Analyses of samples of coal from Anthracite Ridge district, Alaska

\begin{tabular}{|c|c|c|c|c|c|c|c|c|c|c|c|c|}
\hline \multirow[b]{2}{*}{ 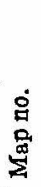 } & \multirow{2}{*}{ 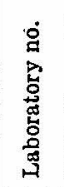 } & \multirow[b]{2}{*}{ Source } & \multirow{2}{*}{ 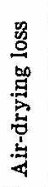 } & \multirow{2}{*}{ 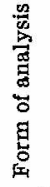 } & \multirow[b]{2}{*}{ 莺 } & \multirow{2}{*}{ 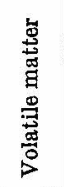 } & \multirow{2}{*}{ 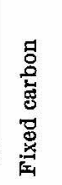 } & \multirow[b]{2}{*}{ स्ञ } & \multirow[b]{2}{*}{ 急 } & \multicolumn{2}{|c|}{ Heating value } & \multirow[b]{2}{*}{ 峦 } \\
\hline & & & & & & & & & & $\stackrel{8}{\stackrel{8}{0}}$ & 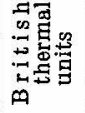 & \\
\hline & & T. 20 N., R. $6 \mathrm{E}$ & & & & & & & & & & \\
\hline 1 & 18101 & $\begin{array}{l}\text { SE1/4NE1/4 sec. } 25 \text { (Chicka- } \\
\text { loon bed } 8 \text { ). }\end{array}$ & 1.2 & $\begin{array}{l}\mathrm{A} \\
\mathrm{C} \\
\mathrm{D}\end{array}$ & \begin{tabular}{c}
1.9 \\
\hdashline \\
\hdashline
\end{tabular} & $\begin{array}{l}21.2 \\
21.6 \\
23.7\end{array}$ & $\begin{array}{l}68.0 \\
69.4 \\
76.3\end{array}$ & $\begin{array}{r}8.9 \\
9.0 \\
\end{array}$ & $\begin{array}{r}0.6 \\
.6 \\
.7\end{array}$ & $\begin{array}{l}7,695 \\
7,845 \\
8,625\end{array}$ & $\begin{array}{l}13,851 \\
14,121 \\
15,525\end{array}$ & 3.2 \\
\hline 1 & 18153 & $\begin{array}{l}\text { SE1/4NE1/4 sec. } 25 \text { (Chick- } \\
\text { aloon bed 5). } \\
\text { T. } 20 \text { N., R. } 6 \text { E. }\end{array}$ & 1.3 & $\begin{array}{l}\mathrm{A} \\
\mathrm{C} \\
\mathrm{D}\end{array}$ & \begin{tabular}{c}
2.1 \\
\hdashline \\
\end{tabular} & $\begin{array}{l}19.6 \\
20.0 \\
21.8\end{array}$ & $\begin{array}{l}70.6 \\
72.1 \\
78.2\end{array}$ & $\begin{array}{r}7.7 \\
7.9 \\
-\end{array}$ & $\begin{array}{l}.6 \\
.6 \\
.6\end{array}$ & $\begin{array}{l}7,803 \\
7,968 \\
8,651\end{array}$ & $\begin{array}{l}14,045 \\
14,342 \\
15,572\end{array}$ & 3.6 \\
\hline 3 & 18040 & $\begin{array}{l}\text { SE1/4SEY/4 sec. } 31 \text { (mouth } \\
\text { of tunnel on east side of } \\
\text { Coal Creek; Spalding } \\
\text { bed). }\end{array}$ & 1.3 & $\begin{array}{l}\mathrm{A} \\
\mathrm{C} \\
\mathrm{D}\end{array}$ & \begin{tabular}{c}
2.5 \\
\hdashline \\
\hdashline
\end{tabular} & $\begin{array}{l}21.0 \\
21.5 \\
23.8\end{array}$ & $\begin{array}{l}67.0 \\
68.7 \\
76.2\end{array}$ & $\begin{array}{r}9.5 \\
9.8 \\
\hdashline\end{array}$ & $\begin{array}{l}.4 \\
.4 \\
.5\end{array}$ & $\begin{array}{l}7,532 \\
7,728 \\
8,565\end{array}$ & $\begin{array}{l}13,558 \\
13,910 \\
15,417\end{array}$ & 3.2 \\
\hline 6 & 18144 & $\begin{array}{l}\text { SW1/4NEY/4 sec. } 33 \text { (bluffs } \\
\text { on south side of Mata- } \\
\text { nuska River). } \\
\text { T. } 20 \text { N., R. } 7 \mathrm{E} \text {. }\end{array}$ & 6.0 & $\begin{array}{l}\mathrm{A} \\
\mathrm{C} \\
\mathrm{D}\end{array}$ & $\begin{array}{c}10.3 \\
-9 . \\
\end{array}$ & $\begin{array}{l}24.7 \\
27.6 \\
34.8\end{array}$ & $\begin{array}{l}46.4 \\
51.7 \\
65.2\end{array}$ & \begin{tabular}{c}
18.6 \\
20.7 \\
\hdashline
\end{tabular} & $\begin{array}{l}.3 \\
.3 \\
.4\end{array}$ & $\begin{array}{l}5,374 \\
5,990 \\
7,556\end{array}$ & $\begin{array}{r}9,673 \\
10,782 \\
13,601\end{array}$ & 1.9 \\
\hline 8 & 4488 & NW1/4SW1/4 sec. 3......... & 0.4 & $\begin{array}{l}\mathrm{A} \\
\mathrm{B} \\
\mathrm{C} \\
\mathrm{D}\end{array}$ & \begin{tabular}{c}
2.2 \\
1.8 \\
\hdashline.-- \\
\hdashline$-\cdot$
\end{tabular} & $\begin{array}{l}16.0 \\
16.1 \\
16.4 \\
17.0\end{array}$ & $\begin{array}{l}78.0 \\
78.3 \\
79.7 \\
83.0\end{array}$ & $\begin{array}{l}3.8 \\
3.8 \\
3.9\end{array}$ & $\begin{array}{l}.6 \\
.6 \\
.6 \\
.6\end{array}$ & $\begin{array}{l}7,851 \\
7,883 \\
8,024 \\
8,353\end{array}$ & $\begin{array}{l}14,130 \\
14,190 \\
14,445 \\
15,035\end{array}$ & 4.9 \\
\hline 12 & 4809 & SW1/4NE1/4 sec. 11 & 4.7 & $\begin{array}{l}\mathrm{A} \\
\mathrm{B} \\
\mathrm{C} \\
\mathrm{D}\end{array}$ & $\begin{array}{r}6.4 \\
1.8 \\
\hdashline-.- \\
\hdashline--\end{array}$ & $\begin{array}{r}8.6 \\
9.0 \\
9.2 \\
11.4\end{array}$ & $\begin{array}{l}66.5 \\
69.8 \\
71.0 \\
88.6\end{array}$ & $\begin{array}{l}18.5 \\
19.4 \\
19.8\end{array}$ & $\begin{array}{l}.3 \\
.3 \\
.3 \\
.4\end{array}$ & $\begin{array}{l}6,001 \\
6,297 \\
6,409 \\
7,993\end{array}$ & $\begin{array}{l}10,800 \\
11,335 \\
11,535 \\
14,390\end{array}$ & 7.7 \\
\hline 13 & 4484 & NW1/4SE1/4 sec. 11 & 3. 6 & $\begin{array}{l}\mathrm{A} \\
\mathrm{B} \\
\mathrm{C} \\
\mathrm{D}\end{array}$ & $\begin{array}{r}7.2 \\
3.7 \\
\hdashline \\
\hdashline\end{array}$ & $\begin{array}{l}26.3 \\
27.3 \\
28.4 \\
31.3\end{array}$ & $\begin{array}{l}57.7 \\
59.9 \\
62.1 \\
68.7\end{array}$ & $\begin{array}{l}8.8 \\
9.1 \\
9.5\end{array}$ & $\begin{array}{l}.7 \\
.7 \\
.8 \\
.8\end{array}$ & $\begin{array}{l}6,433 \\
6,673 \\
6,935 \\
7,655\end{array}$ & $\begin{array}{l}11,580 \\
12,010 \\
12,485 \\
13,780\end{array}$ & 2.2 \\
\hline 14 & 4480 & SW1/4NW1/4 sec. $12 \ldots$ & 2.4 & $\begin{array}{l}\mathrm{A} \\
\mathrm{B} \\
\mathrm{C} \\
\mathrm{D}\end{array}$ & \begin{tabular}{c}
4.9 \\
2.5 \\
\hdashline..- \\
\hdashline
\end{tabular} & $\begin{array}{r}8.1 \\
8.3 \\
8.5 \\
10.1\end{array}$ & $\begin{array}{l}71.8 \\
73.6 \\
75.5 \\
89.9\end{array}$ & $\begin{array}{r}15.2 \\
15.6 \\
16.0 \\
-\end{array}$ & $\begin{array}{l}.7 \\
.7 \\
.7 \\
.8\end{array}$ & $\begin{array}{l}6,495 \\
6,655 \\
6,833 \\
8,132\end{array}$ & $\begin{array}{l}11,690 \\
11,980 \\
12,300 \\
14,635\end{array}$ & 8.9 \\
\hline 19 & 4490 & SE1/4NW1/4 sec. $12 \ldots . . . .$. & 2.0 & $\begin{array}{l}\mathrm{A} \\
\mathrm{B} \\
\mathrm{C} \\
\mathrm{D}\end{array}$ & $\begin{array}{r}4.5 \\
2.6 \\
-2 . \\
-. . \\
\end{array}$ & $\begin{array}{r}9.4 \\
9.6 \\
9.8 \\
11.7\end{array}$ & $\begin{array}{l}70.9 \\
72.3 \\
74.2 \\
88.3\end{array}$ & $\begin{array}{l}15.2 \\
15.5 \\
16.0\end{array}$ & $\begin{array}{l}.3 \\
.3 \\
.3 \\
.4\end{array}$ & $\begin{array}{l}6,539 \\
6,672 \\
6,846 \\
8,141\end{array}$ & $\begin{array}{l}11,770 \\
12,010 \\
12,325 \\
14,655\end{array}$ & 7.6 \\
\hline 20 & 4444 & $\begin{array}{l}\text { SE1/4NW1/4 sec. } 12 \text { (upper } \\
\text { bench). }\end{array}$ & 6.0 & $\begin{array}{l}\mathrm{A} \\
\mathrm{B} \\
\mathrm{C} \\
\mathrm{D}\end{array}$ & \begin{tabular}{c}
7.2 \\
1.3 \\
\hdashline \\
\end{tabular} & $\begin{array}{r}9.1 \\
9.7 \\
9.8 \\
10.8\end{array}$ & $\begin{array}{l}75.4 \\
80.2 \\
81.3 \\
89.2\end{array}$ & $\begin{array}{r}8.3 \\
8.8 \\
8.9 \\
\end{array}$ & $\begin{array}{l}.2 \\
.2 \\
.2 \\
.3\end{array}$ & $\begin{array}{l}6,959 \\
7,403 \\
7,502 \\
8,233\end{array}$ & $\begin{array}{l}12,525 \\
13,325 \\
13,505 \\
14,820\end{array}$ & 8.3 \\
\hline 20 & 4486 & $\begin{array}{l}\mathrm{SE} 1 / 4 \mathrm{NWH}_{4} \text { sec. } 12 \text { (com- } \\
\text { bined sample from sec- } \\
\text { ond and third benches). }\end{array}$ & 1.4 & $\begin{array}{l}\mathrm{A} \\
\mathrm{B} \\
\mathrm{C} \\
\mathrm{D}\end{array}$ & $\left|\begin{array}{c}3.1 \\
1.8 \\
\hdashline \\
\hdashline\end{array}\right|$ & $\begin{array}{r}9.3 \\
9.4 \\
9.6 \\
10.4\end{array}$ & $\begin{array}{l}80.6 \\
81.7 \\
83.2 \\
88.6\end{array}$ & $\begin{array}{r}27.0 \\
7.1 \\
7.2 \\
-\end{array}$ & $\begin{array}{l}.7 \\
.7 \\
.7 \\
.8\end{array}$ & $\begin{array}{l}7,457 \\
7,563 \\
7,696 \\
8,292\end{array}$ & $\begin{array}{l}13,425 \\
13,615 \\
13,855 \\
14,925\end{array}$ & 8.7 \\
\hline
\end{tabular}


COAL

Analyses of samples of coal from Anthracite Ridge district, Alaska-Contd.

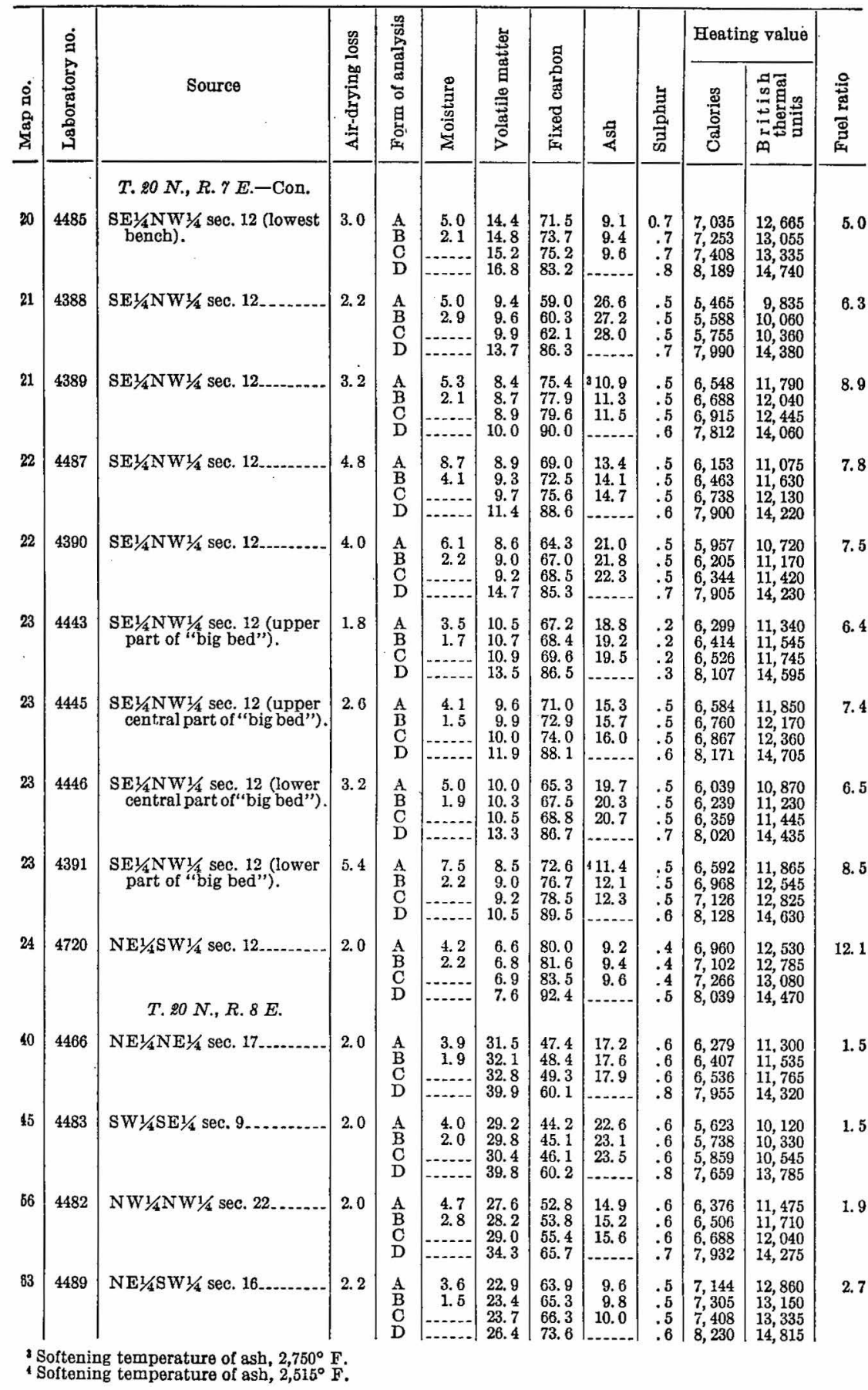




\section{GEOLOGY OF ANTHRACITE RIDGE COAL DISTRICT, ALASKA}

Analyses of samples of coal from Anthracite Ridge district, Alaska-Contd.

\begin{tabular}{|c|c|c|c|c|c|c|c|c|c|c|c|c|}
\hline \multirow[b]{2}{*}{ 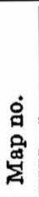 } & \multirow{2}{*}{ 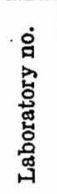 } & \multirow[b]{2}{*}{ Source } & \multirow{2}{*}{ 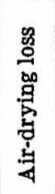 } & \multirow{2}{*}{ 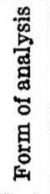 } & \multirow[b]{2}{*}{ 量 } & \multirow{2}{*}{ 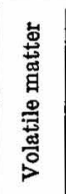 } & \multirow[b]{2}{*}{ 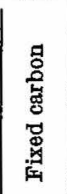 } & \multirow[b]{2}{*}{ 路 } & \multirow[b]{2}{*}{ 葷 } & \multicolumn{2}{|c|}{ Heating value } & \multirow[b]{2}{*}{ 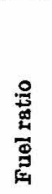 } \\
\hline & & & & & & & & & & 营 & 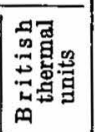 & \\
\hline & & T. 20 N., R. 7 E. & & & & & & & & & & \\
\hline 70 & 4481 & SW1/4NW1/4 sec. $23 . .$. & 2.6 & $\begin{array}{l}\mathrm{A} \\
\stackrel{\mathrm{B}}{\mathrm{C}} \\
\mathrm{D}\end{array}$ & $\begin{array}{r}6.8 \\
4.3 \\
-\end{array}$ & $\begin{array}{l}29.9 \\
30.7 \\
32.1 \\
35.6\end{array}$ & $\begin{array}{l}54.1 \\
55.5 \\
58.0 \\
64.4\end{array}$ & $\begin{array}{l}9.2 \\
9.5 \\
9.9\end{array}$ & $\begin{array}{l}0.6 \\
.6 \\
.7 \\
.7\end{array}$ & $\begin{array}{l}6,394 \\
6,565 \\
6,861 \\
7,615\end{array}$ & $\begin{array}{l}11,510 \\
11,815 \\
12,350 \\
13,705\end{array}$ & 1.8 \\
\hline 72 & 4808 & NW1/4SW1/4 sec. 23 & 1.3 & $\begin{array}{l}\mathrm{A} \\
\mathrm{B} \\
\mathrm{C} \\
\mathrm{D}\end{array}$ & $\begin{array}{r}1.9 \\
0.6 \\
\hdashline-1.9\end{array}$ & $\begin{array}{l}16.4 \\
16.6 \\
16.8 \\
18.1\end{array}$ & $\begin{array}{l}74.2 \\
75.2 \\
75.6 \\
81.9\end{array}$ & $\begin{array}{l}7.5 \\
7.6 \\
7.6 \\
-.\end{array}$ & $\begin{array}{l}.7 \\
.7 \\
.7 \\
.8\end{array}$ & $\begin{array}{l}7,692 \\
7,794 \\
7,838 \\
8,492\end{array}$ & $\begin{array}{l}13,845 \\
14,030 \\
14,110 \\
15,285\end{array}$ & 4.5 \\
\hline 79 & 4479 & $\begin{array}{l}\text { NE } 1 / 4 \text { NE } 1 / 4 \text { sec. } 26 \\
\text { T. } 20 \text { N., R. } 8 \text { E. }\end{array}$ & 1.7 & $\begin{array}{l}\mathrm{A} \\
\stackrel{\mathrm{B}}{\mathrm{C}} \\
\mathrm{D}\end{array}$ & $\begin{array}{r}4.0 \\
2.4 \\
\hdashline-. . \\
\hdashline\end{array}$ & $\begin{array}{l}19.9 \\
20.2 \\
20.7 \\
21.3\end{array}$ & $\begin{array}{l}73.7 \\
75.0 \\
76.8 \\
78.7\end{array}$ & $\begin{array}{r}2.4 \\
2.4 \\
2.5\end{array}$ & $\begin{array}{l}.7 \\
.7 \\
.7 \\
.8\end{array}$ & $\begin{array}{l}7,665 \\
7,798 \\
7,987 \\
8,186\end{array}$ & $\begin{array}{l}13,795 \\
14,035 \\
14,375 \\
14,735\end{array}$ & 3.8 \\
\hline 89 & 4806 & $\begin{array}{l}\text { SW1/4NE1/4 sec. } 27 \text { (upper } \\
\text { bed). }\end{array}$ & 1.5 & $\begin{array}{l}\mathrm{A} \\
\mathrm{B} \\
\mathrm{C} \\
\mathrm{D}\end{array}$ & $\begin{array}{r}2.5 \\
1.0 \\
\hdashline-2 \\
\hdashline-2 .\end{array}$ & $\begin{array}{l}15.0 \\
15.2 \\
15.4 \\
16.0\end{array}$ & $\begin{array}{l}78.4 \\
79.6 \\
80.4 \\
84.0\end{array}$ & $\begin{array}{r}4.1 \\
4.2 \\
4.2 \\
-. .\end{array}$ & $\begin{array}{l}.5 \\
.5 \\
.5 \\
.5\end{array}$ & $\begin{array}{l}7,806 \\
8,016 \\
8,101 \\
8,451\end{array}$ & $\begin{array}{l}14,210 \\
14,430 \\
14,580 \\
15,210\end{array}$ & 5.2 \\
\hline 89 & 4807 & $\begin{array}{l}\text { SW } 1 / 4 \mathrm{NE} 1 / 4 \text { sec. } 27 \text { (lower } \\
\text { bed). } \\
\text { T. } 20 \text { N., R. } 7 E .\end{array}$ & 1.5 & $\begin{array}{l}\mathrm{A} \\
\mathrm{B} \\
\mathrm{C} \\
\mathrm{D}\end{array}$ & $\begin{array}{r}2.2 \\
0.7 \\
\hdashline-2 \\
\hdashline-. .\end{array}$ & $\begin{array}{l}14.3 \\
14.5 \\
14.7 \\
16.5\end{array}$ & $\begin{array}{l}72.2 \\
73.3 \\
73.8 \\
83.5\end{array}$ & $\begin{array}{l}11.3 \\
11.5 \\
11.5\end{array}$ & $\begin{array}{l}.7 \\
.7 \\
.7 \\
.8\end{array}$ & $\begin{array}{l}7,310 \\
7,421 \\
7,471 \\
8,450\end{array}$ & & 5.0 \\
\hline & 4800 & $\begin{array}{l}\text { NW1/4NE1/4 sec. } 14 \text { (north- } \\
\text { west drill hole; coal vein- } \\
\text { lets at } 475 \text { feet). }\end{array}$ & 1.0 & $\begin{array}{l}\mathrm{A} \\
\mathrm{C} \\
\mathrm{D}\end{array}$ & $\begin{array}{l}13.4 \\
13.5 \\
20.7\end{array}$ & $\begin{array}{l}51.3 \\
51.9 \\
79.3\end{array}$ & $\begin{array}{l}34.3 \\
34.6\end{array}$ & & & & & 3.8 \\
\hline & 4801 & $\begin{array}{l}\text { NW1/4NW1/4 sec. } 13 \text { (north- } \\
\text { east drill hole; coal } \\
\text { veinlets at } 605 \text { and } 705 \\
\text { feet). }\end{array}$ & 1.0 & $\begin{array}{l}\mathrm{A} \\
\mathrm{C} \\
\mathrm{D}\end{array}$ & $\begin{array}{l}19.5 \\
19.7 \\
36.2\end{array}$ & $\begin{array}{l}34.4 \\
34.7 \\
63.8\end{array}$ & $\begin{array}{r}45.1 \\
45.6 \\
-\end{array}$ & & & & & 1.7 \\
\hline & 4805 & $\begin{array}{l}\text { SE1/4NE1/4 sec. } 14 \text { (cen- } \\
\text { tral drill hole; coal } \\
\text { veinlets at } 310 \text { and } 490 \\
\text { feet). }\end{array}$ & 0.5 & $\begin{array}{l}\mathbf{A} \\
\mathbf{C} \\
\mathbf{D}\end{array}$ & $\begin{array}{l}28.3 \\
28.4 \\
35.4\end{array}$ & $\begin{array}{l}51.6 \\
51.9 \\
64.6\end{array}$ & $\begin{array}{l}19.6 \\
19.7\end{array}$ & & & & & 1.8 \\
\hline & 4872 & $\begin{array}{l}\text { SE1/4SW1/4 sec. } 14 \text { (south- } \\
\text { west drill hole; coal } \\
\text { veinlets at } 300 \text { and } 425 \\
\text { feet). }\end{array}$ & 0.3 & $\begin{array}{l}\mathrm{A} \\
\mathbf{C} \\
\mathbf{D}\end{array}$ & $\begin{array}{l}24.0 \\
24.1 \\
32.3\end{array}$ & $\begin{array}{l}50.3 \\
50.4 \\
67.7\end{array}$ & $\begin{array}{r}25.4 \\
25.5 \\
-\cdots\end{array}$ & & & & & 2.1 \\
\hline & 4874 & $\begin{array}{l}\text { SW1/4SE1/4 sec. } 14 \text { (south- } \\
\text { southwest drill hole; } \\
\text { coal veinlets at } 728 \text { feet). }\end{array}$ & 0.7 & $\begin{array}{l}\mathrm{A} \\
\mathrm{C} \\
\mathrm{D}\end{array}$ & $\begin{array}{l}16.4 \\
16.5 \\
28.1\end{array}$ & $\begin{array}{l}42.1 \\
42.4 \\
71.9\end{array}$ & $\begin{array}{l}40.8 \\
41.1\end{array}$ & & & & & 2.6 \\
\hline & 4803 & $\begin{array}{l}\text { SE1/4SE1/4 sec. } 14 \text { (south } \\
\text { drill hole; coal veinlets } \\
\text { at } 96 \text { and } 198 \text { feet). }\end{array}$ & 0.3 & $\begin{array}{l}\mathrm{A} \\
\mathrm{C} \\
\mathrm{D}\end{array}$ & $\begin{array}{l}29.2 \\
29.3 \\
42.4\end{array}$ & $\begin{array}{l}39.6 \\
39.7 \\
57.6\end{array}$ & $\begin{array}{l}30.9 \\
31.0\end{array}$ & & & & & 1.4 \\
\hline & 4873 & $\begin{array}{l}\text { SE1/4SE1/4 sec. } 14 \text { (south } \\
\text { drill hole; coal veinlets } \\
\text { at } 1,003 \text { and } 1,092 \text { feet). }\end{array}$ & 0.5 & $\begin{array}{l}\mathrm{A} \\
\mathrm{C} \\
\mathrm{D}\end{array}$ & $\begin{array}{l}23.6 \\
23.7 \\
29.8\end{array}$ & $\begin{array}{l}55.7 \\
56.0 \\
70.2\end{array}$ & $\begin{array}{l}20.2 \\
20.3\end{array}$ & & & & & 2.4 \\
\hline & 4804 & $\begin{array}{l}\text { NEL/4SW } 1 / 4 \text { sec. } 13 \text { (south- } \\
\text { east drill hole; coal in- } \\
\text { clusions at } 652 \text { to } 655 \\
\text { feet). }\end{array}$ & 0.4 & $\begin{array}{l}\mathrm{A} \\
\mathrm{C} \\
\mathrm{D}\end{array}$ & $\begin{array}{l}28.3 \\
28.5 \\
31.5\end{array}$ & $\begin{array}{l}61.4 \\
61.6 \\
68.5\end{array}$ & $\begin{array}{r}9.9 \\
9.9 \\
\hdashline\end{array}$ & & & & & 2.2 \\
\hline & 4802 & $\begin{array}{l}\text { NE1/SW1/4 sec. } 13 \text { (south- } \\
\text { east drill hole; coal in- } \\
\text { clusions at } 980 \text { feet). }\end{array}$ & 0.5 & $\begin{array}{l}\mathrm{A} \\
\mathrm{C} \\
\mathrm{D}\end{array}$ & $\begin{array}{l}18.5 \\
18.6 \\
32.2\end{array}$ & $\begin{array}{l}39.0 \\
39.2 \\
67.8\end{array}$ & $\begin{array}{r}42.0 \\
42.2 \\
-\end{array}$ & & & & & 2.1 \\
\hline & 4799 & $\begin{array}{l}\text { NE1/4SW } 1 / 4 \text { sec. } 13 \text { (south- } \\
\text { east drill hole; coal vein- } \\
\text { lets and inclusions at } \\
1,520 \text { and } 1,610 \text { feet). }\end{array}$ & 0.8 & $\begin{array}{l}\mathrm{A} \\
\mathrm{C} \\
\mathrm{D}\end{array}$ & $\begin{array}{l}17.6 \\
17.6 \\
30.5\end{array}$ & $\begin{array}{l}40.2 \\
40.7 \\
69.5\end{array}$ & $\begin{array}{l}41.4 \\
41.7 \\
\end{array}$ & & & & & 2.3 \\
\hline
\end{tabular}


The analyses show that in the Anthracite Ridge district there are coals ranging from anthracite to bituminous in rank. Although some of the bituminous coals have a fuel ratio as low as 1.5, they do not have the physical characteristics of subbituminous coals. None were seen which break down to powder.

The relation of the rank of coal to the structure is not clear from the analyses. In some of the faulted and closely folded localities the coals do not seem to be appreciably improved in rank by the pressure and heat to which they must have been subjected. Analysis 4483, representing coal which has been closely folded, shows a fuel ratio of only 1.5, whereas analysis 4482, representing coal of the same or nearly the same horizon where gently dipping, shows a fuel ratio of 1.9. However, coals to the southeast, near the faulted contact with the Upper Cretaceous rocks, are shown by analyses 4806 and 4807 to have fuel ratios of 5.2 and 5.0. Similar local effects of severe movement and possibly also the effect of intrusive rock are shown by analyses 4479 and 4808 , with fuel ratios of 3.8 and 4.5 for coals near lower Purinton Creek; but farther up the stream the more severely crushed coal of analysis 4481 had a fuel ratio of only 1.8 .

The effect of local metamorphism seems to be shown by analysis 4809 , of coal with a fuel ratio of 7.7, not far from the coal of analysis 4484, having a fuel ratio of only 2.2. The coals of highest rank were confined to the area in sec. 12 , T. 20 N., R. 7 E., high on the ridge, which has been intruded by thick masses of diabase and later intensely folded and faulted. The heat from the masses of igneous rock apparently drove off some of the volatile matter from the coal and produced the high-rank coals of this small area. Later additional alteration of the coals by heat produced during the compression and folding of the beds may also have taken place. Of the 14 analyses of samples from this area, 12 show the coals to be semianthracites. One sample (analysis 4485) ranks only as semibituminous because of its rather high volatile content, which shows less pronounced devolatilization of this coal than of the others sampled. The southernmost sample (analysis 4720) ranks as true anthracite, having a fuel ratio of 12.1 .

All the samples of coal analyzed from the area of relatively gently dipping beds where the core holes were drilled showed fuel ratios of only 1.4 to 2.6 , except at the northwest drill hole, where coal veinlets a few feet below a 25 -inch sill of diabase were of semibituminous rank and noncoking. The other nine drill-hole samples were of bituminous coking coals. 


\section{DIAMOND-DRILL HOLES}

\section{LOCATION}

The beds of high-rank coal on central Anthracite Ridge are in a small area of much faulting and crushing, but it seemed possible that they might be found to continue southward underground and be less crushed and intruded by sills in the synclinal area in secs. 13 and 14. Accordingly it was decided to test this area with the diamond drill, and eight holes were put down in 1932, covering an area about three quarters of a mile square. The locations are shown on plate 2 (two holes being drilled at the southwest location). After completion, each drill hole was marked by a post set in it and bearing a metal disk stamped "Drill hole."

All the holes were carried as deep as was feasible, the drilling being suspended only when the condition of the hole rendered it very risky to the tools to continue deeper. In the deepest hole the bit and lower portion of the drill rods were lost, owing to caving of the walls of the hole. Nearly all the core from all the holes was preserved. It afforded unweathered specimens of the materials penetrated but seemed on preliminary examination to contain little of unusual interest and has not yet been examined in detail.

\section{NORTHERN DRILL HOLES}

The northern drill holes encountered materials which were much more fractured than had been expected. These holes showed that for more than half a mile beyond the base of the ridge the beds are greatly faulted and crushed. The logs of the northern holes, reduced to true thicknesses of the beds penetrated, are given on plate 12, together with the corresponding section exposed along Purinton Creek, and arranged, as nearly as the data would permit, on a common stratigraphic horizon. The sandstone at the top of the central drill hole is exposed 40 yards eastward in the bank of Purinton Creek. The diabase sill near the top of the northeast drill hole seems to conform in horizon with the sill at 200 feet (true thickness) in the central drill hole and with the sill at 94 feet in the northwest drill hole. This sill is probably rot so definite a marker as a distinctive sandstone or shale would be, but such a definite bed was not present.

At the northwest drill hole the beds at the surface dip $40^{\circ} \mathrm{S}$. This dip flattens somewhat for the first 250 feet in depth, then steepens to about $45^{\circ}$ for the remainder of the hole. In this hole 14 sills were penetrated, from 9 inches to 9 feet 8 inches in thickness. From the lower two, which were greatly fractured, an artesian flow of 10 gallons a minute of slightly sulphureted water was obtained. Some of the coarse-grained sandstones contain fragments of coal; and at several depths the shale and sandy' shale carry veinlets of coal $1 / 32$ to $1 / \mathrm{S}$ inch thick. At numerous horizons there are also plant remains as carbonized films. In some places this is fragmentary material which was evidently deposited as such before being carbonized; but at many horizons there are well-preserved leaf impressions. An analysis of a sample of coal from veinlets at depth of 475 feet ( 340 feet in the true-thickness $10 \mathrm{~g}$ ) is given on page 44 and shows the material to be of semibituminous rank. 
The high ash content is probably due to shale dust unavoidably included in the scraping from the drill core, and the relatively high rank of the coal may have been produced by some devolatilization by heat from an adjacent thin sill.

At the northeast drill hole a fairly uniform dip of $20^{\circ}$ to $25^{\circ}$ was found in the beds. Only five sills were penetrated in this hole, one near the top, three thin ones in the third quarter of the depth, and a shattered sill near the bottom. This lowest sill yielded an artesian flow of 8 gallons a minute of slightly sulphureted water, similar to that from the bottom of the northwest drill hole. Below 500 feet the beds were at some horizons much shattered and slickensided, and calcite reinlets were common at these places. The analysis of a combined sample of coal scraped from veinlets in core from depths of 605 and 705 feet (545 and 635 feet in the true-thickness $\log$ ) is given on page 44 and shows it to be of bituminous rank. This sample was considerably lower in fixed carbon and higher in volatile matter than the sample from the northwest drill hole, where the rocks are more extensively intruded by sills.

In the central drill hole, except for an 8-inch stringer of diabase near the top, only one sill was penetrated. The sandstones of this hole are coarsergrained than in the holes farther north, and several of them may be classed as grits. All these coarser beds contain fragments of coal, in part as angular fragments of an inch in greatest dimensions but chiefly as lenticular patches a fraction of an inch thick. The coaly material so intimately fills fractures in the grits that it appears to have been formed in place from woody fragments or peaty muck included in the deposit. Some fragments retain the recognizable shape and markings of seed cones. None of the fragments have the appearance of rounded pebbles of coal included in the coarse-grained beds. A combined sample of coal from the fragments in grits at 310 and 490 feet in depth (290 and 460 feet in the true-thickness $10 \mathrm{~g}$ ) was analyzed (p. 44). It is similar, on the ash-free basis, to that from the northeast drill hole; but the sample showed less ash, because cleaner coal for analysis was obtained from the coal fragments in the grits than could be obtained from reinlets in shale.

The sequence of beds along Purinton Creek does not accord with the logs of the neighboring central and northeast drill holes, nor do these agree very well with each other. The three sections demonstrate how greatly the beds vary in character within short distances. In the shales and sandy shales the change is probably due chiefly to variation in the texture of the beds themselves, but the beds of sandstone and grit are lenticular and do not continue for more than a few hundred yards before pinching out.

\section{SOUTHERN DRILL HOLES}

The logs of the five southern drill holes, reduced to true thickness of beds penetrated, are given on plate 13 . Because of the variation in the character of the sedimentary beds no good horizon marker could be found common to these five holes. A diabase sill encountered in the three western holes at about the same depth in each seems to offer a fairly definite horizon for correlation; and the data on the structure warrant correlating this sill with the diabase found in the south drill hole at nearly 400 feet and in the southeast drill hole at about 350 feet. In the lower portions of the three western holes and at around 800 feet in the other two there is a zone containing sandstone and grit. If the logs were correlated on this zone, the diabase band would appear to cut somewhat across the belding, which may be its true position. 
The southwest A drill hole was put down at an angle nearly perpendicular to the dip of the surface beds, at the same location as the southwest drill hole, after the latter had found the beds to increase in dip from $10^{\circ}$ at the surface to $50^{\circ}$ near the bottom and had encountered fractured, slickensided rocks in a fault zone. Both drill holes penetrated much the same alternation of beds in their upper portions; but at the bottom of the southwest drill hole the holes were 250 feet apart, and the lower portions of their logs exhibit considerable variation in the beds within this short distance. The analysis on page 44 of a composite sample of coal from veinlets in sandy shale at 300 and 425 feet in the southwest drill hole (210 and 310 feet in the true-thickness $\log$ ) shows the material to be of bituminous rank.

The south-southwest drill hole encountered much the same alternation of beds as the two southwest holes; but the individual beds vary laterally between the two locations. Some of the grits and coarse sandstones are fairly continuous beds, but others are evidently lenticular and were not encountered in the other drill holes along the strike of the beds. The dip of the beds in the south-southwest drill hole was about $20^{\circ}$ near the surface but steepened to $45^{\circ}$ at less than 200 feet and maintained this dip to the bottom. Some of the coarse-grained beds showed considerable cross-bedding. The analysis on piage 44 of a sample of coal from veinlets in shale at 728 feet (515 feet in the true-thickness $\log$ ) shows it to be similar to that of the veinlets in the southwest drill hole, which were 200 to 300 feet higher in the formation.

The south drill hole is on the alluvial fan of Purinton Creek. The upper 75 feet of the hole penetrated gravel which contained water under sufficient artesian pressure to bring it to the surface. Although the location is near the axis of the syncline, the core showed dips of $10^{\circ}$ to $20^{\circ}$, with cross-bedding at angles as great as $45^{\circ}$ at a few horizons. The formation as a whole was found to be finer-grained than it is farther west; although in the upper half of the hole several beds of grit and sandstone were penetrated. In the lower part of the hole the shale and sandy shale were crushed and slickensided at several horizons, as if by faulting. As in the other drill holes, much of the shale is carbonaceous and at some depths contains coal veinlets $\frac{1}{32}$ to $1 / 8$ inch thick. A combined sample was prepared from veinlets at 96 and 198 feet in depth, and a similar sample was prepared from veinlets at 1,003 and 1,092 feet. The analyses on page 44 show them to be bituminous coals. The material from the greater depths is, however, of considerably highel rank, being on the ash-free basis about $12 \frac{1}{2}$ percent higher in fixed carbon and 12 percent lower in volatile matter than the shallower coals.

The southeast drill hole was put down as close to the axis of the syncline as could be determined from the surface evidence available at the time, but later observations on the dip of the surface beds indicate that it is 200 or 300 feet south of the axis. The hole was drilled beside a small stream for convenience of water supply; and flowing artesian water was encountered in the 75 feet of gravel overlying bedrock. The bedding in the cores showed dips ranging from $5^{\circ}$ or $10^{\circ}$ near the surface to $15^{\circ}$ and $20^{\circ}$ in the lower part of the hole. The materials penetrated were more predominantly fine-grained than in any of the other holes. Carbonaceous shale and shale with coal veinlets were encountered at numerous horizons. Samples for analysis were collected from coal inclusions and veinlets at 652-655, 980, 1,520, and 1,610 feet, the material from the last two depths being combined into one sample. The analyses of these samples (p. 44) show them to be rery similar in character, with 67.8 to 69.5 percent of fixed carbon and 30.5 to 32.2 percent of volatile matter, on the moisture and ash-free basis. They all rank as bituminous coals of me- 
dium quality. The high percentages of ash in the two deeper samples are probably due to particles of shale unavoidably included in the material scraped from veinlets for analysis.

\section{SUMMARX}

Figure 3 shows the percentages of the several classes of material penetrated in each drill hole, arranged in decreasing amounts of shale. The northeast, southeast, and southwest drill holes have the highest percentages of fine materials, both of shale and of shale plus sandy shale. The central drill hole has the greatest percentage of coarse-grained material, because of the numerous beds of grit penetrated and also because of the comparative shallowness of this hole, which did not penetrate far into the deeper, more shaly beds. In general, the logs show greater deposition of fine-grained materials in the eastern and southern parts of the area tested by the core drill and more sandy materials in the central and western parts; but there is not a definite gradation of materials over this small area. The rapid local variation rather than progressive gradation is shown by the true-thickness logs of the two holes drilled at the southwest location.

Beds containing plant remains were penetrated at numerous depths in the core holes. At some horizons such material was fragmentary and evidently had been macerated before being incorporated in the deposits; but at several horizons there were well-preserved leaf impressions, and usually these carried the carbonized remains of the leaves.

Appreciable amounts of water were encountered in bedrock only in the northwest and northeast drill holes. In each hole an artesian flow was obtained in a shattered diabase sill. None of the sedimentary beds in any of the drill holes seemed to be water-bearing; and the core recovered, even that of sandstones and grits, was nearly dry.

\section{IMECHANICAL ASPECTS OF THE CORE DRILLING}

As the diamond drilling was carried on in a difficultly accessible area and under unfavorable climatic conditions, it seems worth while to record some of the features of this undertaking.

Specifications. - The contract for the work called for the completion of 8,000 feet of core drilling by the end of 1932 . The terms were $\$ 4.25$ per foot drilled, with an additional $\$ 3$ for each foot of core recovered. All expenses connected with the moving of machinery and the drilling were borne by the contractor, including the set-ups for four drill holes. Additional locations were paid for at $\$ 250$ for each set-up.

Transportation.-The machinery and supplies for the core drilling were taken to the district during February to April 1932, being first moved by horse sled and sled drawn by caterpillar tractor, on the frozen surface of the Matanuska River, for 12 miles beyond the railroad platform at the mouth of 
the Chickaloon River. The cold wind blowing down the river formed snowdrifts in some places and bared the gravel bars in others and added to the difficulty of getting material moved up before the river channels opened.
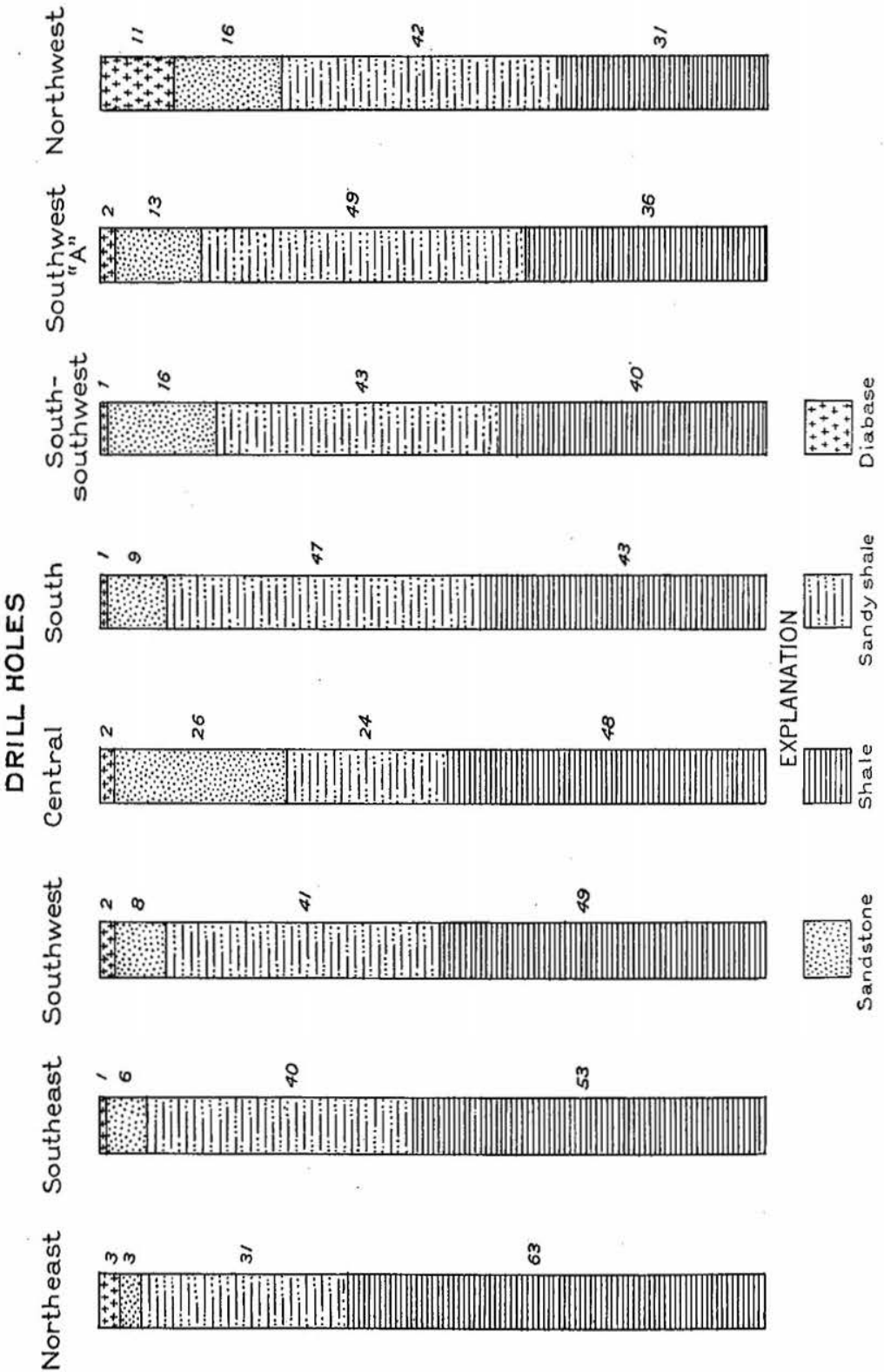

From the 12-mile depot the hauling was done by the tractor up the snowflled ravine of Conglomerate Creek for nearly a mile, and thence by switch-back road out of the ravine and up the intervening slopes the remaining 3 or 4 miles to the drill sites. Up the ravine considerable road making was necessary, 
and for nearly all the distance from the river part of the snow had to be shoveled away before the tractor could make its way through the 4-foot layer that covered the slopes. Camp was established beside Purinton Creek, on the south border of the area to be drilled.

Equipment.-Two drilling machines were used-a Sullivan Machinery Co. type $\mathrm{B}$ with 30-horsepower steam engine, and an E. J. Longyear type $2 \mathrm{~N}$ with 18-horsepower steam engine. Each drill was equipped with hydraulic feed. A 38-horsepower tubular boiler, constructed in sections for mountain transport, was used with each. The set-up of the rig and machinery is shown in plate 14, A.

Fuel.-An attempt was made to obtain fuel from coal outcrops on the ridge, but the expense of developing a supply, either by open cut or by tunnel, and the cost of transporting coal down the steep slopes to the drill sites were found to be excessive; so the spruce timber was used for firing the boilers. The caterpillar tractor worked well over the moss- and brush-covered ground in hauling wood to the drills and also in moving the machinery. After being assembled at the first locations, the boilers, weighing $3 \frac{1}{2}$ tons, were moved on skids to succeeding locations. Gasoline for the tractor was brought from Chickaloon by pack horses, about $\mathbf{1 2}$ gallons a day being consumed. The green spruce, after being cut and allowed to dry for 2 or 3 weeks, kept up steam fairly well. Each boiler burned half to three-quarters of a cord a day at shallow drilling depths, increasing to about $11 / 2$ cords for the lower part of the hole. About 450 cords of wood was burned during the 8,000 feet of drilling. It would have required considerably less if the wood had been well seasoned.

Water supply.-Each drill hole was located within a few yards of a small stream which furnished water for drilling, and except at the south drill hole it was not necessary to use the muddy return water over again. During the later part of the season, when temperatures below zero were experienced, the water intake was through a 2-inch pipe, surrounded by a 4-inch pipe into which the steam from the water pump and engine was exhausted. This gave ample heat to keep the water line, 10 to 20 yards in length, from freezing; and at the creek an oil drum in which a wood fire was maintained kept the intake open.

Drilling method.--In commencing a hole, a chopping bit and water jet were first used to sink a 4-inch standpipe to bedrock. Core drilling was then begun, with diamond bit cutting a 3 -inch hole and recovering core $2 \frac{1}{4}$ inches in diameter. This was continued until caving or other difficulty rendered it necessary to set casing and reduce the size of the hole. Drilling then proceeded with $2 \%$-inch drill, cutting $1 \%$-inch core. The hole was carried with this size until caving prevented further progress without great risk to the tools. A double-tube core barrel was used, which protected the core from the water flush and assured better core recovery in all soft materials. A pump pressure of about 250 pounds to the square inch was used. Care was necessary to stop drilling as soon as the core barrel was filled, as otherwise the core would become crushed. In drilling shale, the bit often became blocked by the clayey cuttings which stopped the water circulation. It was then necessary to pull out and clean the tools.

During the first 300 or 400 feet of drilling, some pressure from the hydraulic feed, in addition to the weight of the drill rods, was used, so as to keep a pressure of about 1 ton on the bit. As the hole deepened, a part of the weight of the rods was carried by the hydraulic feed.

In drilling through the diabase sills in the northwest drill hole some trouble was caused by fragments of the fractured rock slipping from the wall of the hole and wedging against the drill rods. This was overcome by pouring 
in a mixture of portland cement and plaster of paris, which set in 2 or 3 hours sufficiently hard to hold back the fractured pieces and allow drilling to proceed. In the southwest drill hole the return water was lost for a time through porous or fractured rock, which was cemented off in the same way.

Core recovery.-Except in the northwest drill hole, where the core recovery was unusually low, the amount recovered was 92.1 to 96.5 percent of the footage drilled. The loss of core was chiefly in the material of crushed and slickensided zones. In a few places poorly cemented sandstone or grit was penetrated, which crumbled and caused loss of part of the core. In the northwest drill hole several of the diabase sills and the adjacent shales were much broken, and the material was recovered only in fragments.

Often it was necessary to pull out the tools before the full core-barrel length of 10 feet had been drilled, owing to the clogging of the bit and stoppage of the water circulation. For the most part, however, full runs were made; and a few cores were obtained unbroken. Plate $14, B$, shows a $91 / 2$-foot core of sandy shale, $1 \%$ inches in diameter, recovered from the south-southwest drill hole at $674 \frac{1}{2}$ to 684 feet.

Rate of drilling.- The shales were found to be so clayey as to clog the drill bit easily, and as they constitute a large part of the Chickaloon formation, they rendered the rate of drilling much slower than had been expecterl. The sandy shales drilled much more rapidly. The diabase, though hard, cut clean. The sandstones and grits drilled the fastest of all. The rate of actual drilling in these four classes of material, as judged by numerous observations, was about as follows:

\section{Rate of core drilling in different materials}

Shale
Diabase

The rate of drilling in the several holes, based on the time spent in actual drilling operations (drilling, pulling out, removing core, and lowering the rods) is given in the following table.

Rate of core drilling, Anthracite Ridge district, Alaska

\begin{tabular}{|c|c|c|c|c|c|c|c|}
\hline \multirow[b]{2}{*}{ Drill hole } & \multirow[b]{2}{*}{$\begin{array}{l}\text { Total } \\
\text { depth } \\
\text { (feet) }\end{array}$} & \multirow[b]{2}{*}{$\begin{array}{c}\text { Over- } \\
\text { burden } \\
\text { (feet) }\end{array}$} & \multirow[b]{2}{*}{$\begin{array}{l}\text { Amount } \\
\text { cored } \\
\text { (feet) }\end{array}$} & \multicolumn{2}{|c|}{ Core recovery } & \multirow{2}{*}{$\begin{array}{l}\text { Drilling } \\
\text { time } \\
\text { (hours } \\
\text { actually } \\
\text { spent in } \\
\text { core- } \\
\text { drilling } \\
\text { opera- } \\
\text { tions) }\end{array}$} & \multirow[b]{2}{*}{$\begin{array}{c}\text { Rate of } \\
\text { drilling } \\
\text { (feet per } \\
\text { hour) }\end{array}$} \\
\hline & & & & Feet & Percent & & \\
\hline \multirow[t]{2}{*}{$\begin{array}{l}\text { Southeast. } \\
\text { Northeast. } \\
\text { Northwest } \\
\text { Central. } \\
\text { South } \\
\text { Southwest_e } \\
\text { South-southwest } \\
\text { Southwest A }\end{array}$} & $\begin{array}{r}1,8191 / 2 \\
762 \\
793 \\
676 \\
1,110 \\
869 \\
978 \\
9941 / 2\end{array}$ & $\begin{array}{r}74 \\
18 \\
0 \\
0 \\
75 \\
29 \\
21 \\
25\end{array}$ & $\begin{array}{c}1,7451 / 2 \\
744 \\
793 \\
676 \\
1,035 \\
840 \\
957 \\
9691 / 2\end{array}$ & $\begin{array}{c}1,624 \\
699 \\
649 \\
652 \\
954 \\
803 \\
9411 / 2 \\
906\end{array}$ & $\begin{array}{l}93.1 \\
93.9 \\
81.9 \\
96.5 \\
92.1 \\
95.6 \\
96.3 \\
93.4\end{array}$ & $\begin{array}{r}1,444 \\
560 \\
548 \\
444 \\
824 \\
688 \\
752 \\
637\end{array}$ & $\begin{array}{l}1.21 \\
1.33 \\
1.44 \\
1.52 \\
1.25 \\
1.21 \\
1.27 \\
1.52\end{array}$ \\
\hline & 8,002 & 242 & 7,760 & $7,2281 / 2$ & & 5,897 & \\
\hline
\end{tabular}

Core recovery for the 7,760 fect core-drilled was 93.1 percent.

Rate of drilling for the 7,760 feet core-drilled was 1.31 feet per hour. 


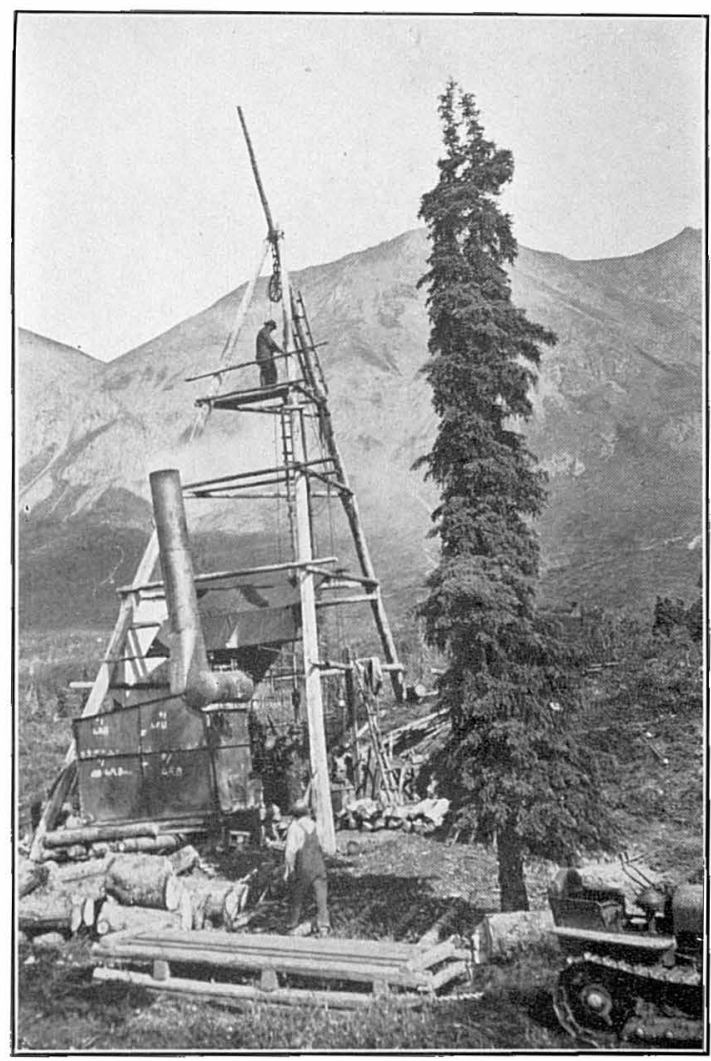

A. DIA MOND CORE DRILL AT NORTHWEST LOCATION ANTHRACITE RIDGE DISTRICT.

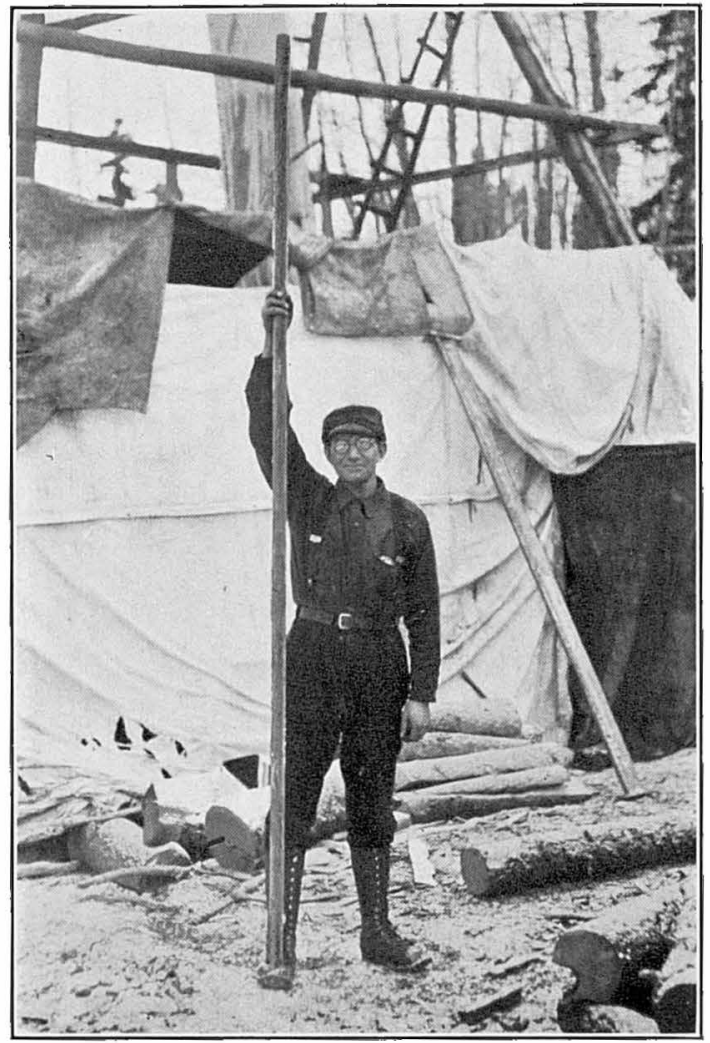

B. DIAMOND-DRILL CORE OF SANDY SHALE 158 INCHES IN DIAMETER, 91\% FEET LONG. 
It will be noted that the rate of drilling varied only between 1.21 and $\mathbf{1 . 5 2}$ feet per hour, the average for the total footage core-drilled being 1.31 feet.

The rate for each drill hole does not bear a direct relation to the proportion of shale present, because in comparing holes of different depths, as the hole deepens the increasing amount of time consumed in pulling out the rods and lowering them obscures the actual drilling speed. However, the two holes with lowest percentages of shale (the northwest and southwest A; see fig. 3 ) were among the highest three in rate of drilling. The central hole, which had as high a drilling rate as the southwest $\mathrm{A}$ hole, had the largest percentage of sandstone and grit and was also the shallowest hole, with therefore the least time spent in pulling out and running in the tools.

The rate of drilling depended also on the steam pressure. Normally, 120 pounds to the square inch was used, but at times with rain-soaked green wood, it was difficult to keep the steam pressure up to 100 pounds. The lower pressure caused less engine power and slower pump action and hence gave slower cutting speed.

The rods were handled in 30 -foot sections ( 3 rods at a time), at an average speed of about 20 feet a minute while pulling out and 25 feet a minute while running back in. With about 10 minutes required to unscrew and empty the core barrel and reassemble it, the time for a complete run at a depth of $\mathbf{5 0 0}$ feet was close to 1 hour.

There was no appreciable difference in drilling rate between the 3-inch and the $23 / 8$-inch bits, as the cutting speed depends largely on the annular speed of the diamonds. Although the larger drill bit has to cut more material, the greater travel of the stones makes up for the smaller area cut by the smaller bit.

In most of the drilling a speed of 200 to 250 revolutions of the drill per minute was used, but in some of the gritty formations vibration was set up in the rods, which slowed and at times almost stopped the drill. This vibration produced spiral grooving of the core in the form of a multiple thread, as each stone cut a thread. The pitch and spacing of these threads were very different on different cores, as they varied with the rate of revolution and the speed of cutting. Greasing of the rods proved to be a very temporary remedy for the vibration, and in four of the holes (the central, south, southwest, and southsouthwest) it was necessary to run casing and reduce the size of the hole, to overcome this difficulty.

Except during the recovery of drill rods at the southeast drill hole, little time was lost on account of repairs or "fishing" jobs. Minor repairs, such as those to the hydraulic head and the brake eccentric, required only a few hours' work in a machine shop but necessitated the trip of nearly 100 miles to Anchorage for that purpose. The work was completed with no serious injuries to the men.

Diamond losses. - In shale and sandy shale the wear on the diamonds was slight. The stones were set so as to project about $1 / 40$ inch beyond the steel of the bit, and a bit could be used for drilling 200 feet or more before the steel shell become worn down so as to require resetting of the stones. The actual wear of the eight stones in a bit was probably equivalent to not more than 10 cents per foot drilled, based on a price of about $\$ 120$ per carat for the stones.

In the earlier drilling carbons (black diamonds) were used; but after the loss of the bit in the southeast drill hole, the cheaper borts (white diamonds) were employed; and although they did not cut so fast in the harder beds, they gave satisfactory service. Three times stones were broken from the bit as the drill was being run back to the bottom, apparently by striking projecting fragments of diabase or grit. In the southwest $A$ hole the stones were 
noticeably worn by grits encountered at about 526 and 680 feet (470 and 595 feet in the true-thickness $\log$, pl. 13). These grits apparently contain some unusually hard pebbles of quartzite or chert.

\section{CONCLUSIONS}

The coal outcrops shown on plates 2 and 3 and described in the preceding pages include all the showings of consequence in the district. Although in some places there are coal beds several feet thick, the slight extent of these beds should be emphasized. None of them continue along their outcrops for more than a few hundred feet before either pinching out or grading into coaly shale and shale. The absence of coal outcrops from much of the area is due to the absence of coal deposition. In what seemed to be the most likely area for the presence of coal beneath the surface, diamond-drill holes proved that there are no beds of coal down to well below a possible commercial depth.

The demand for coal in Alaska is not great, and although in recent years only about two-thirds of the amount consumed has been produced from mines in the Territory, they could easily supply the other third if lack of bunkers at Seward and the cost of freight and shipping did not cause some of the coastal markets to be supplied by coal from Washington and British Columbia.

Under present conditions the bituminous coals of the Anthracite Ridge district cannot compete in markets of the Territory with the more accessible coals of similar rank already developed in the lower Mantanuska Valley. The anthracite and semianthracite of the district constitute so small a tonnage that it is very doubtful whether the amount recoverable would justify the costs of development. These high-rank coals would find only a very slight market within the Territory, for blacksmithing and possibly for foundry use. The remoteness of outside markets for these premium fuels and the consequent cost of delivering them would render them of little commercial interest at this time, even if they were present in much greater amount and under more favorable conditions of mining. 


\section{INDEX}

\begin{abstract}
Page
Acknowledgments for aid_._..... 6-7

Alaska Matanuska Coal Co., opera-$$
\text { tions by }
$$

Analyses of coal, forms of

Animal life

Anthracite, definition of

anthracite Ridge, correlation of coal beds in central part of

outcrops of coal beds on

views showing

weather record at camp near.-

Anthracite Ridge district, geologic maps of -- pls. 2, 3 (in pocket)

structural features of pls. 2-4 (in pocket)
\end{abstract}

Baxter mine, operation of

Bentonite, occurrence of, in Chickaloon formation _..... 13-1

Bituminous coal, definition of _-_ 40-41

Boundaries of district_-_...-_-_-_ 3

Campbell, M. R., quoted

Capps, S. R., work of

40

Cascade Creek, carbonaceous deposits in

structure on east branch of up. per

Chapin, Theodore, work of

ihickaloon, coal from, analyses of-coal from, rank of

tests of, by United States Navy_-_..............

coal beds at, character of outerops of _..._- 29-30 sections of stratigraphic position of - 26

mining and prospecting at_---- 24-25

weather record at.--

Chickaloon Coal Co., operations by --

Chickaloon formation, age and correlation of -

bentonite in, occurrence of ._- 13-14

contact of, with Matanuska formation

kaolinite in, occurrence of

lithology of _._-_._._. 12-14, pl. 6

occurrence of $\quad 11$

relation of, to Kenai formation--

thickness of

Chikootna Creek, outcrops of coal beds on

Chugach Mountains, view of, from

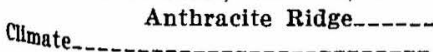

cis
occurrence and character of ..- 10-11,
Coal, analyses of Page classitication of ......... $40-41$ deposits of, features of mining of, outlook for........ 54
Coal beds, correlation of metamorphism of _..._-____-_ 26 outcrops of pIs. $1-3,8,9$ (in pocket) sections of _- 31 , pl. 9 (in pocket) stratigraphic position of _...-- 27-29 structure of _-___- pl. 8 (in pocket) views showing _-_._._._._. pls. 10, 11 Coal Creek area, coal of, rank of _-_ 26 coal beds in, outcrops of --_-- $\quad 30$ sections of - 31 prospecting of - 25

Conglomerate Creek, outcrop of Upper, position of, with respect to the coal beds

Cretaceous time, events of

Diabase sills, occurrence and character of _._._- 15 , pl. 10

position of, with respect to the coal beds_.._._._._._. 27-29

Doherty mine, development and operation of

Drainage, features of

Drill core, $9 \frac{1}{2}$-foot length of --- 52, pl. 14

Drill holes, location of northern, features of pl. 12 (in pocket) recovery of cores from southern, features of pl. 13 (in pocket) true-thickness $\operatorname{logs}$ of pls. 12, 13 (in pocket)

Drilling, equipment used in mechanical aspects of method of rate of

Eocene time, events of

Eska conglomerate, age of occurrence, character, and thickness of _... 14-15

Iska Creek Coal Co., operations of -- 23

Eska mine, coal of, character of _._- 26 operation of

Evan Jones mine, development of _- 23 $\begin{array}{rrr}\text { pl. } 5 & \text { stratigraphic position of coal } & \\ 7-9 & \text { beds at } & \end{array}$ 
Page

Faulting, occurrence of _.._ 18-20, pls. 5, 7

Field work for present report

Folding, occurrence of

Foran, W. T., work of

17-18

Geologic explorations, previous

3-6

Geologic history

Geologic maps_----- pls. 1, 2, 3 (in pocket)

Gerdine, T. G., work of

Glacial deposits, occurrence and character of

Glenn, Capt. E. F., expedition of --

Granitic rocks, occurrence and character of_-______ $10, \mathrm{pl} .5$

Habitations in the district

Hicks Creek, coal reported on

Hill, Capt. W. P. T., work of

Intrusive rocks, age of occurrence and character of $15-16$

Jurassic rocks, occurrence and character of

Jurassic time, events of

Kaolinite, occurrence of, in Chickaloon formation

Katz, F. J., work of

IKenai formation, relation of, to Chickaloon formation.

Kings River, coal on, character of -. coal beds on

Knopf, Adolph, work of

Kutzkatna Creek, outcrops of coaly shale on

structure on Anthracite Ridge east of..._. $18, \mathrm{pl} .6$

Landes, K. K., work of ..._...... 5-6

Lignite, definition of -

Location of district

Martin, G. C., work of

Matanuska formation, contact of, with Chickaloon formation --

occurrence and character of _.. 10

Matanuska River, outcrops of coal beds on _._._._._- 30,39

Matanuska Valley, upper, geologic map of _-_- pl. 1 (in pocket)

upper, structural features of _.. 16-17

Meadow Creek, outcrops of coal beds on branches of

Mendenhall, W. C., work of

Mertie, J. B., Jr., work of _.......-.

Metamorphism, effect of, on coal.--

Miller coal bed, character and thickness of

Mining, coal, outlook for-...

Miocene time, events of

Moose Creek, coal on, character of-coal beds on, stratigraphic position of
Muddy Creek, coal beds on, correla tion of coal beds on, outcrops of _ 35-39, pl.11

Navy Alaskan Coal Commission, exploratory work of operations by, at Chickaloon--New Black Diamond Coal Co., prop-

New Black Diamond Coal Co., prop-
erty of

Newsome, L. O., work of

O'Brien Creek, outcrops of coal beds on

Ohlson," Col, O. F., investigations entrusted by, to United States Geological Survey

Olsen coal bed, character and thickness of

Overbeck, R. M., work of

Packsaddle Gulch, outcrops of coal beds in and near.... 35 ,

Paige, Sidney, work of $36,37,39$

Pioneer mine, development and operation of

Pliocene time, events of

Precipitation, records of _.......- 8

Premier mine, development of _-_- 22

Purinton Creek, coal beds on, correlation of coal beds on, outerops of $37-38$, pls. 10,11

drill holes near. $46-48$

Quaternary deposits, occurrence and character of

16

Rawson mine, operation of -_-..-_. 22

Recent . deposits, occurrence and character of

Recent time, events of

Reeside, J. B., Jr., fossils identified by

Relief, features of

Richards, R. W., work of

Ross, C. S., quoted

Sargent, R. H., work of _._._. 5

Savage, T. E., work of

Semiantbracite, definition of -...-- 40

Semibituminous coal, definition of _. 40

Sharp, M. L., analyses of coal by-- $42-44$ burning test of coal by- 34

spalding coal bed, analysis of coal from

character and thickness of _... 25

Stratigraphy - . $10-16$

Structure, features of pls. $2-4$ (in pocket), $5-\pi, 8$ (in pocket)

relation of rank of coal to views showing 
Subbituminous coal, definition of ----

Page

Talkeetna formation, occurrence and character of

Temperature, records of

Tertiary rocks, occurrence and character of

Timber

United States Bureau of Mines, analyses of coal by

leasing of coal-bearing areas by_ $\quad 22$ United States Navy, prospecting

United States Senate, special committee of, recommendations of

Township descriptions :
T. 19 N., R. 6 E.
T. 19 N., R. 8 E...... $39-40$
T. 20 N., R. 5 E______._- 29-30
T. 20 N., R. 6 E._... 30
T. 20 N., R. 7 E_____-_ 30-34, 37-38
T. 20 N., R. 8 E
Tukmakna Creek, outcrops of coal

34-35

Vegetation

Winding Creek, outcrop of coal bed on---

Wishbone Hill Coal Co., production by-_-24-23

Young Creek, coal on, character of -- 26 coal beds on 



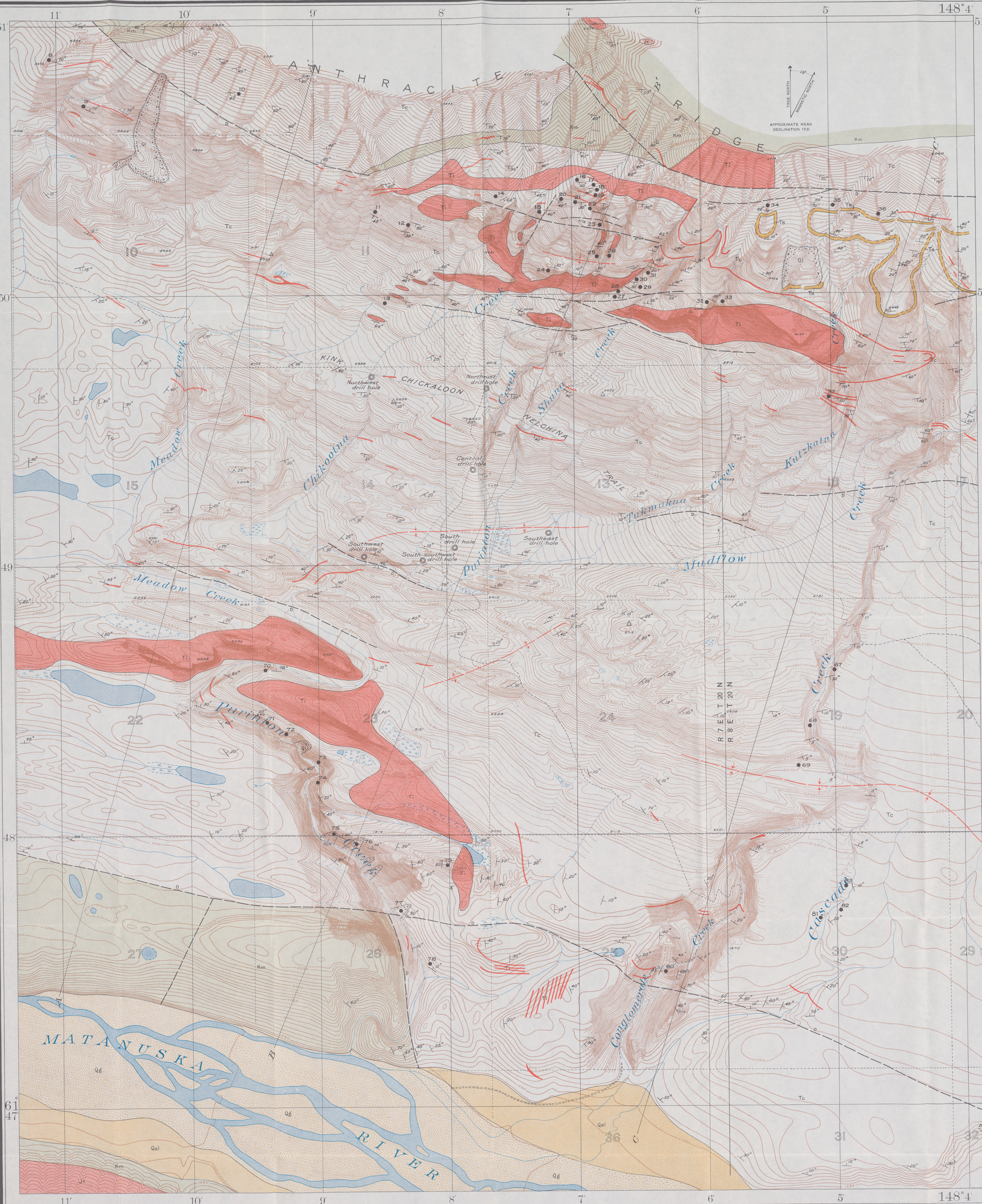

EXPLANATION
SEDIMENTARY ROCKS

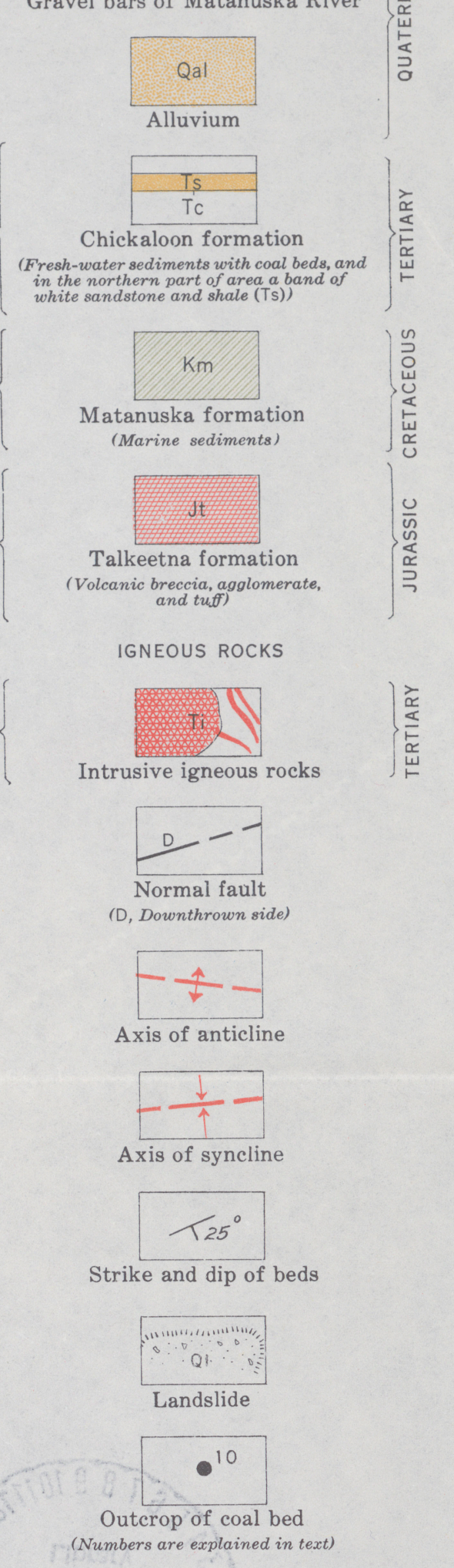




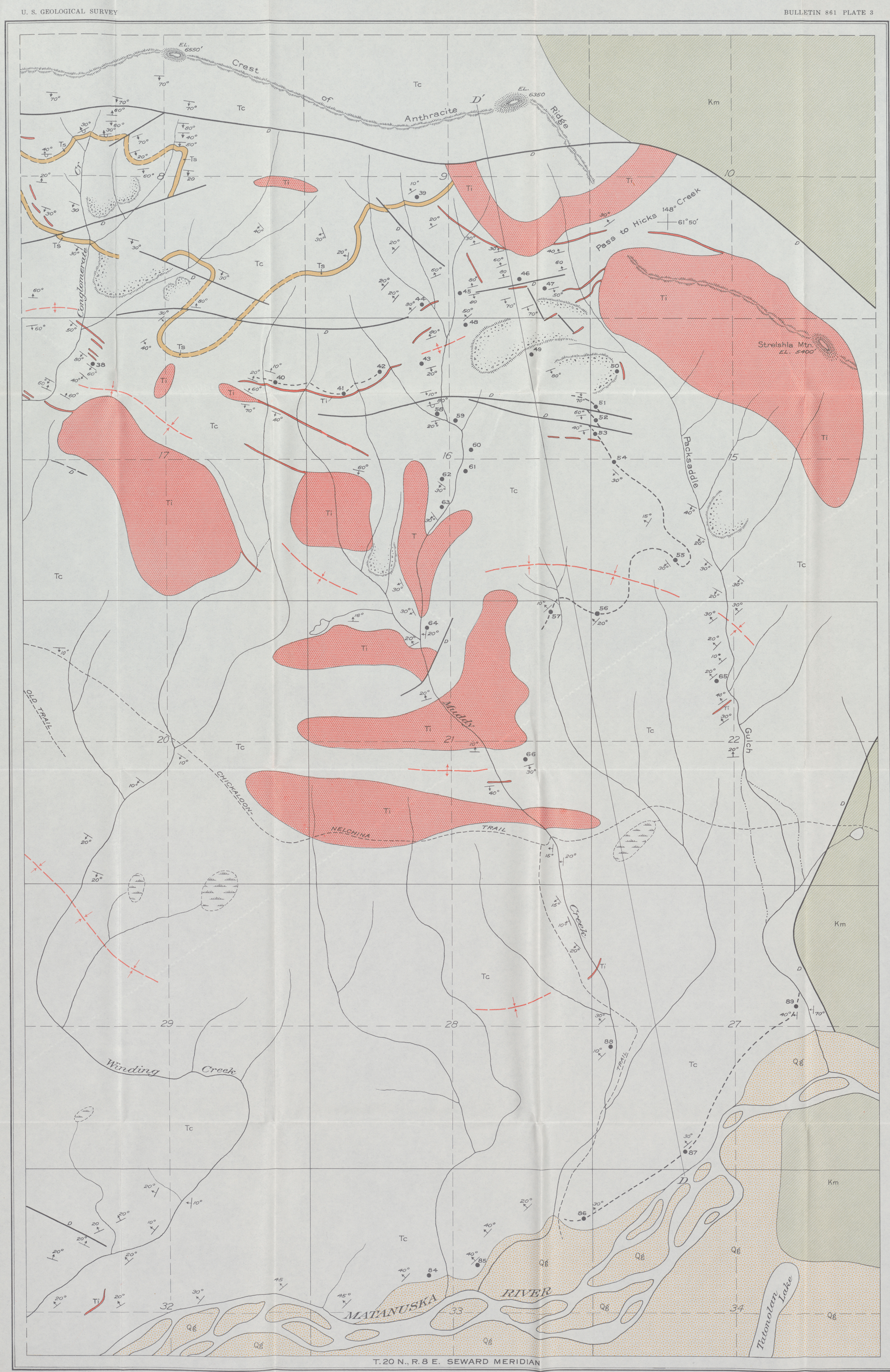

EXPLANATION

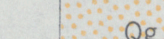

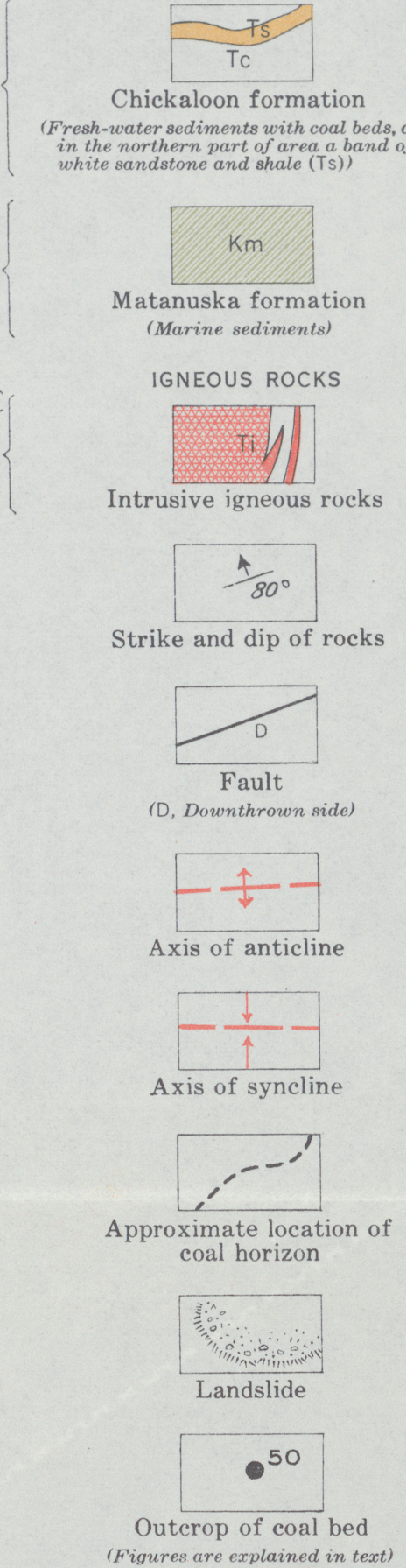




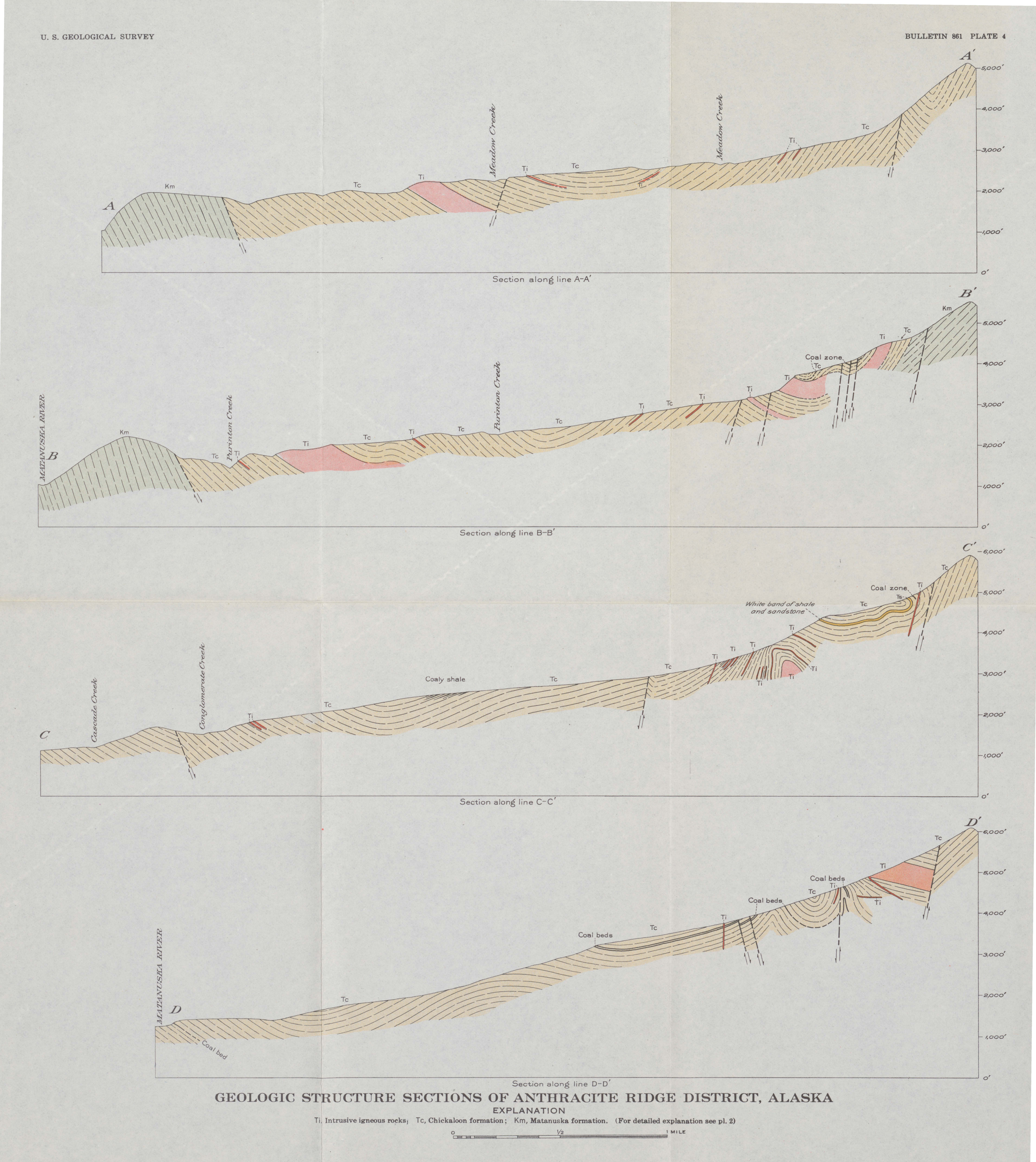




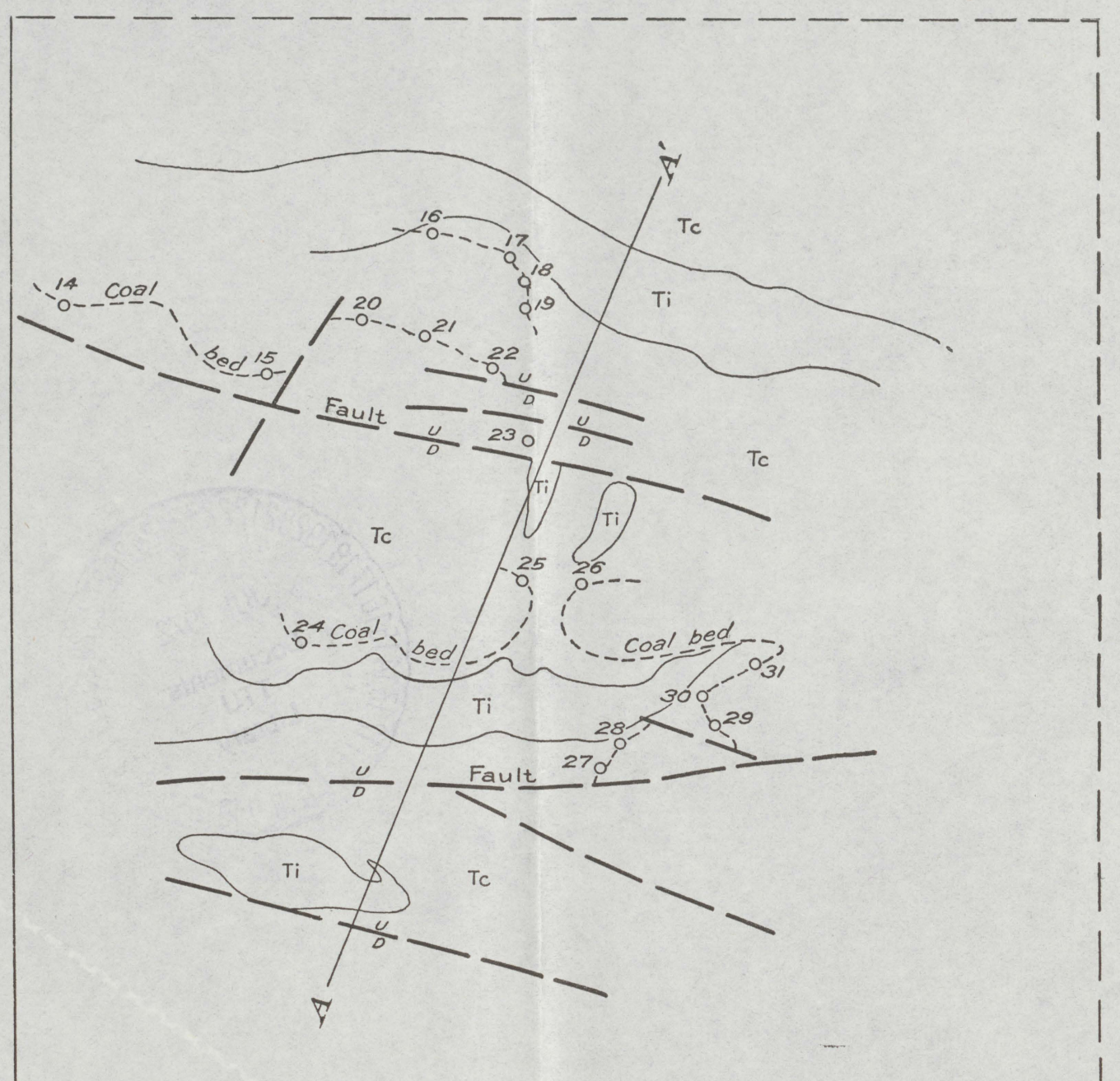

Sec. 12, T. 20 N.,R.7 E.

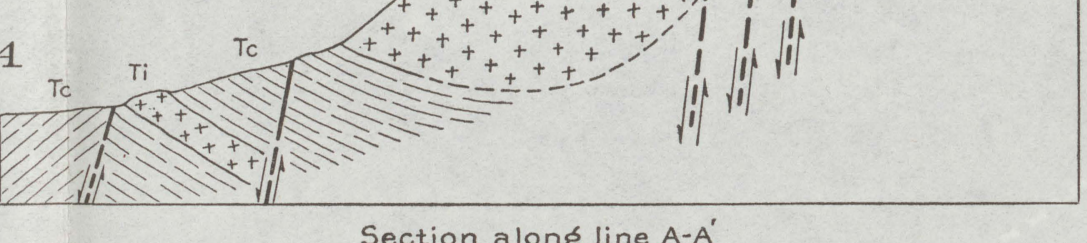

Section alonǵ line $A-A$
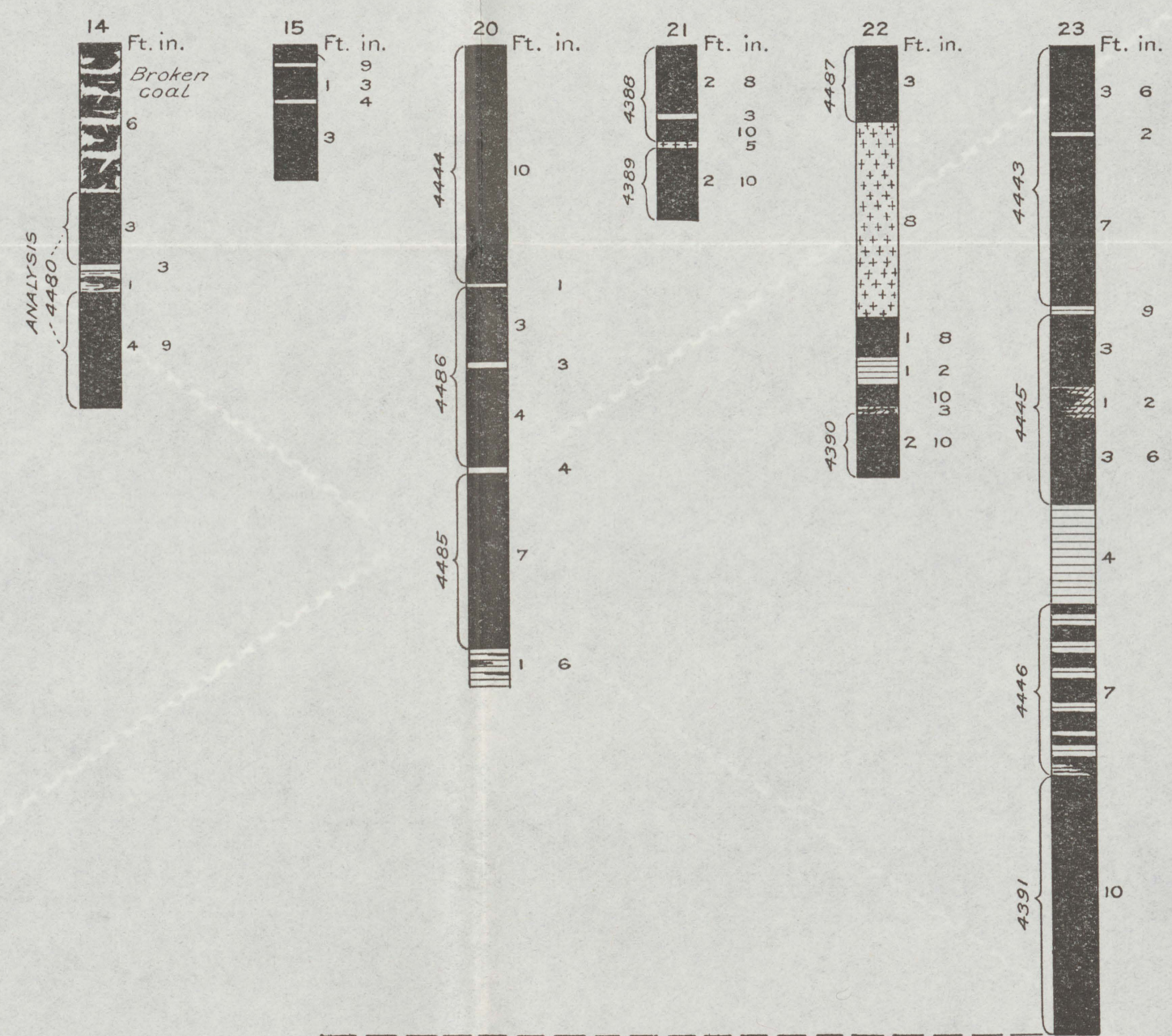

1 I
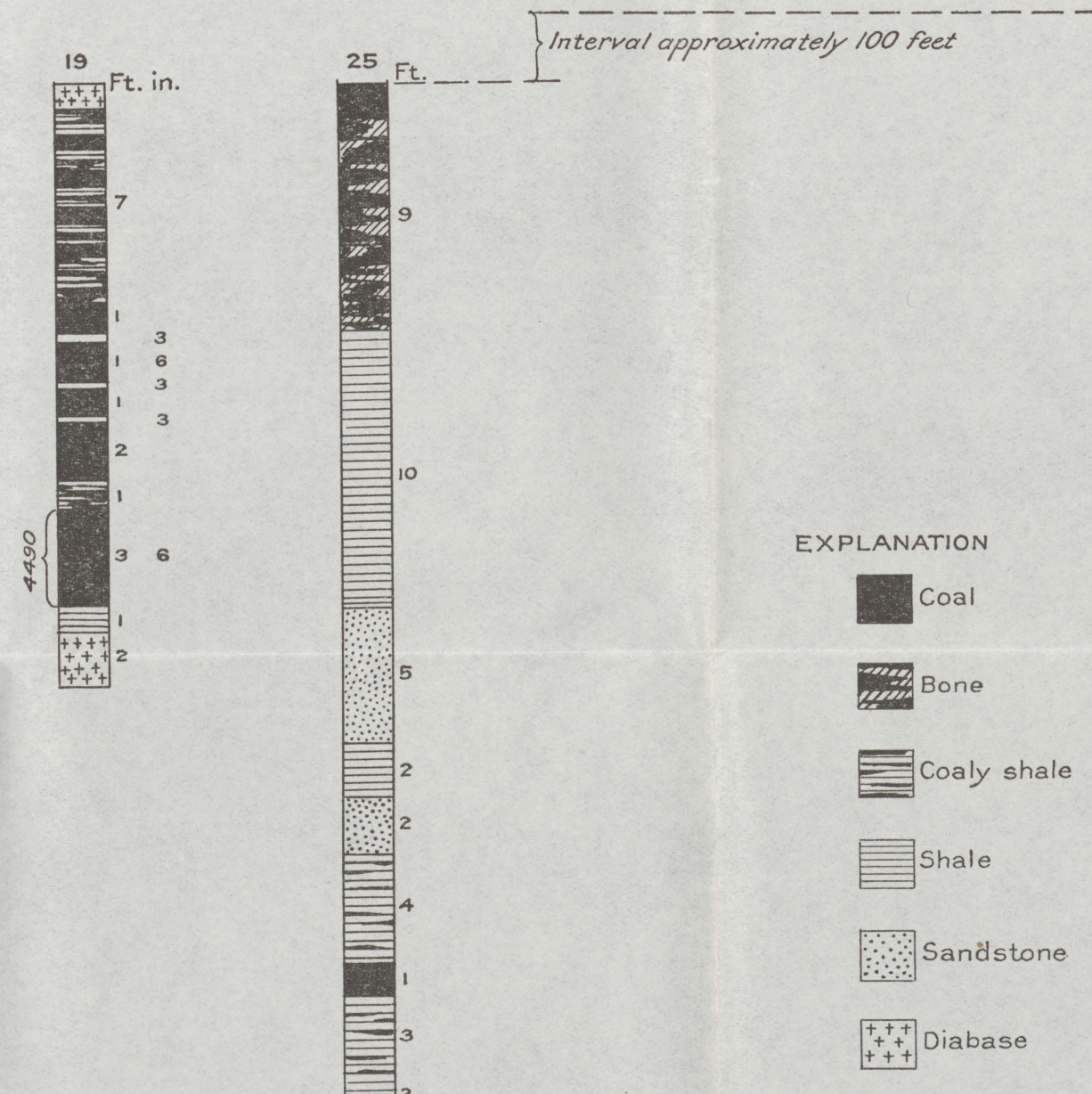

STRUCTURE OF COAL BEDS IN SEC. 12, T. 20 N., R. 7 E. 


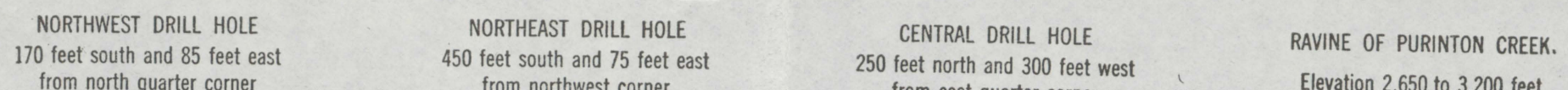

\section{Northwest arill hole} $e^{x^{2}}$

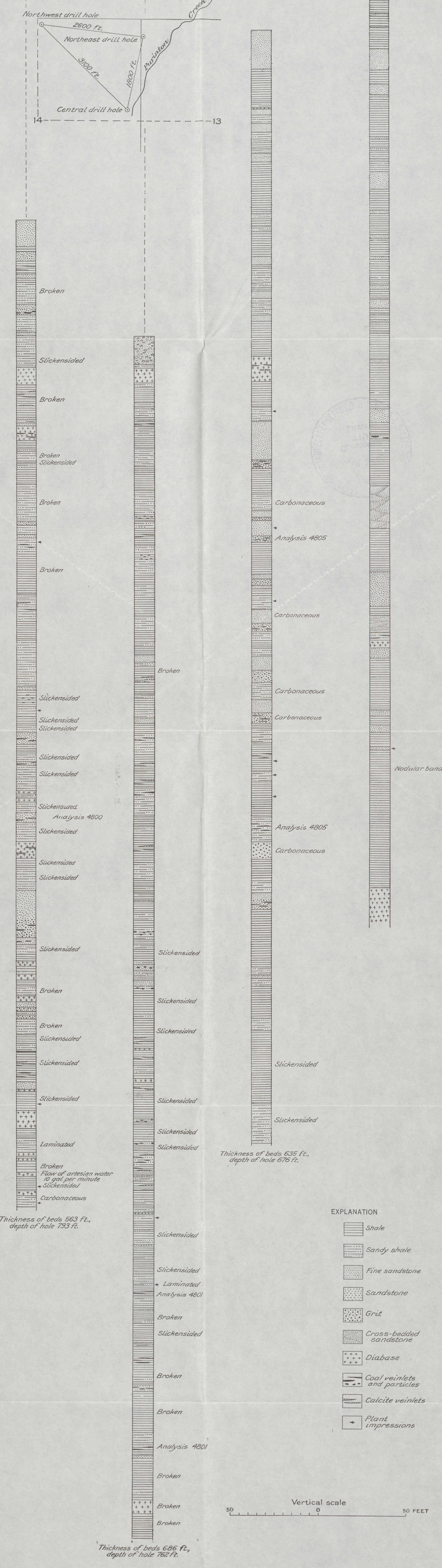




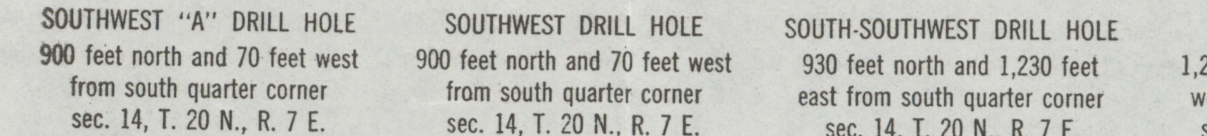

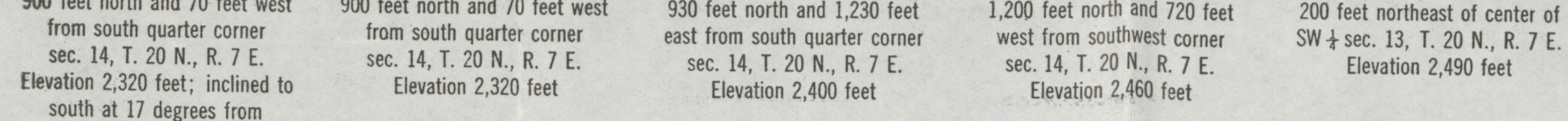

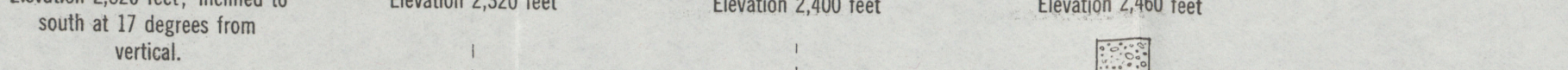

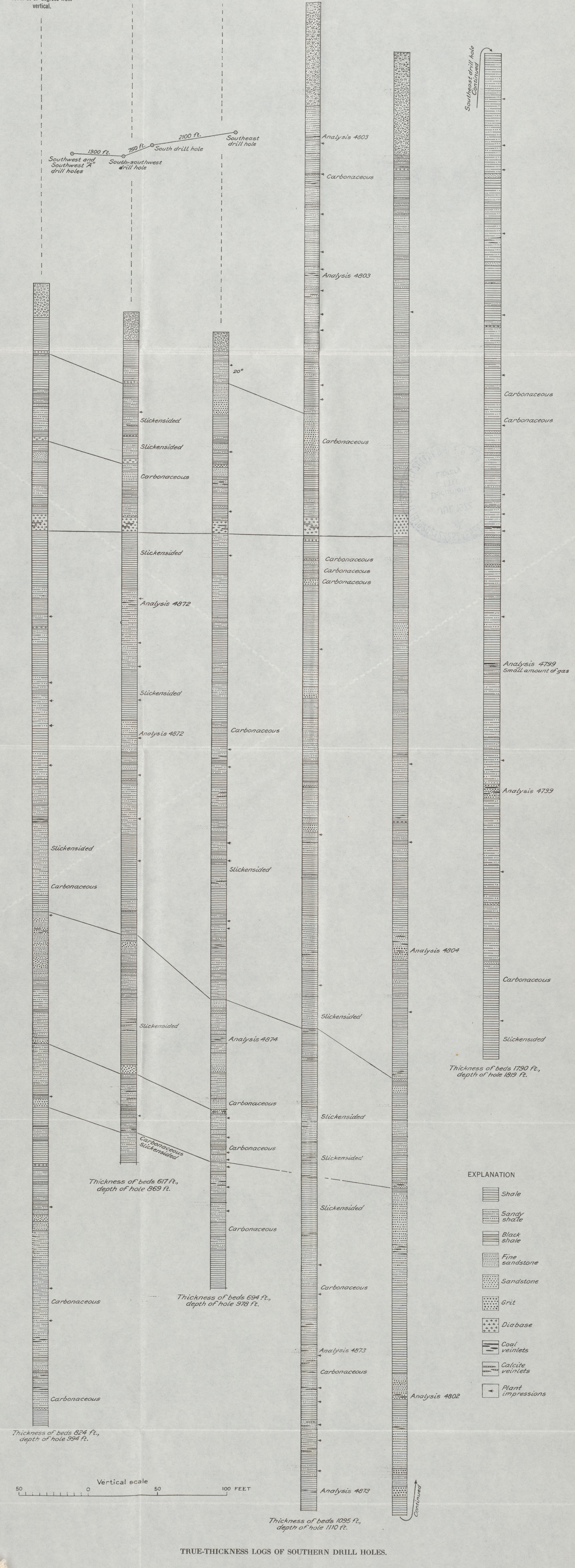


